\title{
ON THE CAMPUS
}

MACB́RIDE 


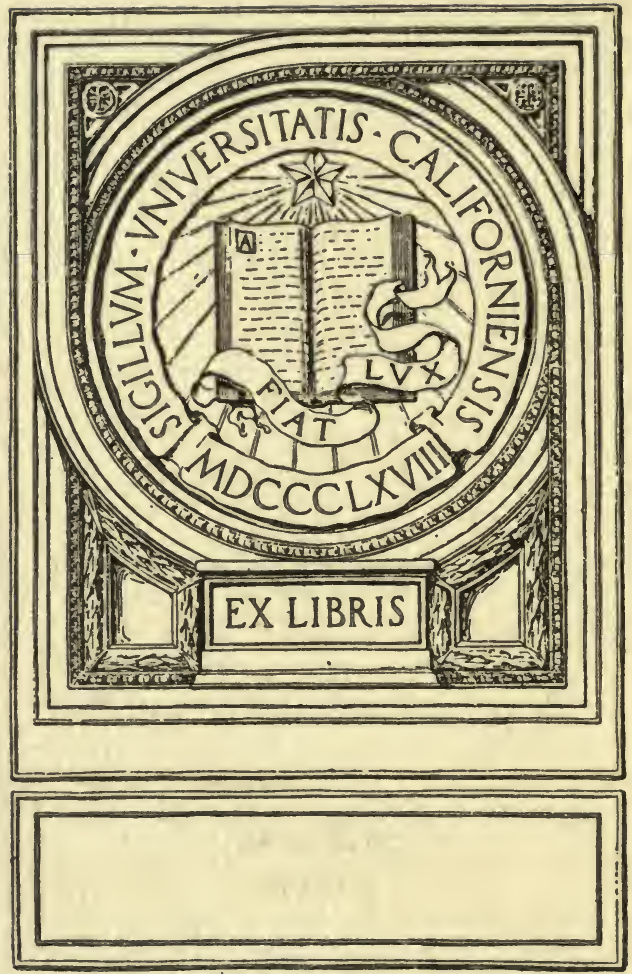



Digitized by the Internet Archive in 2007 with funding from Microsoft Corporation 


\section{ON THE CAMPUS}





\section{ON THE CAMPUS}

ADDRESSES DELIVERBD AT VARIOUS TIMES

BEFORE UNIVERSITY AND COL-

LEGE AUDIENCES

\section{BY \\ THOMAS H. MACBRIDE}

PRESIDENT STATE UNIVERSITY OF IOWA

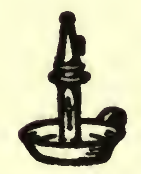

THE TORCH PRESS

CEDAR RAPIDS, IOWA

1916 
Coptright 1916 BY

Thomas H. MaCbride

THE TORCH PRESS

CEDAR RAPIDS

IOWA 



\section{CONTENTS}

Things Worth While in Education . . 11

Address before the literary societies of Lenox College at Commencement, June, 1908

Culture and the State . . . . . 34

Address at the fifty-ninth Commencement of Monmouth College, June 8, 1915

The Teacher aND THE State
Address before the graduating class of the Iowa

State Teachers' College, June 9, 1914

The Success of the Public Schools

Address before the Northeastern Iowa Teachers'

Association, Clinton, April 2, 1915

Culture and Women's Clubs .

Address before the State Federation of Women's

Clubs of Minnesota, February 12, 1916

The Gifts of Science

Address delivered on the dedication of Science Hall, University of South Dakota, June 16, 1902

The Response of Plants.

Address before the Baconian Club of the State University of Iowa, December, 1903

The Alamogordo Desert: The Plant's ReSPONSE to Changes Terrestrial - $\cdot$.
Presidential address before Section G, American Association for the Advancement of Science, Philadelphia, December 28, 1904 
The Plant's Response to Human Agencx 173 Address before the Baconian Club of the State University of Iowa, December, 1904

Point Lobos: The Plant's Response to Forces

Cosmic . . . . . . . . . 194

Address before the Baconian Club of the State University of Iowa, December, 1902

The Botany of Shakespeare . . . . 209 Address before the Contemporary Club of Davenport, Iowa, 1899

The Folk-Lore of Plants . . . . 234 Address before the Iowa Branch of the American Folk-lore Society, November 26, 1909

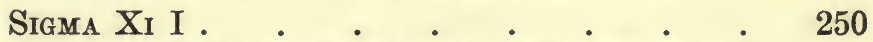

President's address before the Iowa Chapter and the Initiates, the Class of 1902

Sigma XI II

Charge to Initiates, before the Iowa Chapter and the Class of 1914 




\section{THINGS WORTH WHILE IN EDUCATION}

It is needless for me to tell you that for the student there is about these early days of summer a charm that comes not of air or earth or sky. True, all these as they appear in June are proverbial. "What so rare as a day in June." The earth is fecund, the air translucent, the sky pure with the freshness of Nature's morning; all things animate and inanimate rejoice. But the student sees all this richness in a different way. June may be fair to everyone else, but for the student it is fairer still. For him was this particular season made; all its splendors are but the gorgeous setting of his stage. Has he not waited its coming all the year? For him the seasons are but a journey, a travelled way, that leads, sometimes in light, sometimes in shadow, always through toil and effort, up to June, to radiant June. This is commencement and the world is here; not light only, not only blossoms and glad faces, and fine raiment and the voice of song, - but the real world to which all days and weeks and years are but an anticipation. Commencement, like faith, is for every happy student everywhere, "the substance of things hoped for, the evidence of things not seen."

Now on such a day as this I count myself happy to come back here to June and youth, and for the hour at least to share the enthusiasm of those who rejoice to 
shout and sing and to realize that for them and theirs the world begins to-day. Pessimistic indeed would he be who should in his vain heart imagine that his world were the only world; that the concerns of life as these appear to older people are alone real and substantial, and that the gladness of youth and the all-importance of its affairs, shall not also find appropriate mention in the epic which depicts the life-experience of the race.

Nevertheless, I suppose all will allow that one who looks back upon a scene like this in his own history may see some things unnoted by those who share its gayety, or even by those who, hasting forward along the way yet hold in expectation, hold largely in anticipation, the joys of a commencement day.

The mountains which divide the continent and determine the course of rivers and the floating of rain-clouds, are as we pass them, full of beauty; of leafy groves and brilliant flowers and the music of flitting birds; only as we recede do these things all more or less disappear, and we see at last, only those things which are eternal, the immovable peaks, the impregnable walls, the unfailing caps of snow that make possible and perennial the springs and streams and rivers and rains to gladden the wide habitable world. And so in the course of life; experience teaches us at last those things which are best; and while we may never cease to find interest in everything that can concern or engage the attention of intelligent people, nevertheless it is more easy for us to see that some things are more nearly universal than others, and therefore more worthy of perpetual appreciation and esteem. 
Therefore, I come to you to-day with such a theme as that just announced; to the undergraduate, advice; merely a reminder to the graduate, and for us older folk a theme of appropriate reflection. Besides, for some of our complexity and perplexity as well, education is herself responsible. We have grown complex. To my father, the content of my subject suggested no special difficulty. Life's duties were plain. Life itself was simple and the preparation for it of correspondingly modest compass. In my grandfather's family the problem was possibly more simple still. The young people were taught to read and write; to memorize hymns and passages of scripture, the rules of good behavior and how to do things that their fathers and mothers could do; the lads to swing an axe, to plow, to plant, to reap, to handle tools; the girls, to sew and knit and spin and weave, to embroider, to sing, to cook, to care for the sick - all alike at length to settle down quietly in homes of their own to live with their children the same quiet, uneventful lives. This was the ordinary procedure. There was no thought of more general or extended culture, and the vast benefits to be derived from the universality of learning were as yet unheard of. Only if a lad were destined for the pulpit, or the bar, was a different education thought of. Indications for this destiny were discovered not as a rule in mental gift or intellectual aptitude, but in reverse physical quality; a puny body, or indifferent health, unfitting a boy for the rigorous service of a farm or shop, were pretty sure to send him a candidate for medicine or the service of the church.

The lad sent to college experienced, however, in those 
days no difficulty in finding things worth while in education. If he had found any such embarrassment, his instructors had quickly solved his problem for him. There is the course of study; it is four years long. It has always been the same; it is neither too long nor too short; as the priest says about the church, quod semper, quod ubique, quod ab omnibus. This course of study has served all the men of the past centuries in all the world; it will serve you. There were no electives - there was nothing to make electives of, and there had been no choice if there had been electives offered.

Now it may be remarked at the outset that it is by no means doubtful that these people, our predecessors, found the things essential in education. There is no doubt they found the results. They found intellectual and moral life and health; they found appreciation and happiness and power, and in so far were blessed. Nevertheless, it is equally a matter of no smallest doubt that within the last fifty years the whole fashion of the world has changed. Up to the middle of the last century men were living in all civilized countries very much as men had lived for two or three thousand years. The plantings and sowings and buildings and all domestic arts of the Iowa pioneers were not unlike those which Pliny describes on the hills and valleys of Italy and Spain twenty centuries ago. In our houses we had window-glass, our greatest invention, cast-iron stoves, and wooden floors. Beyond this I know of nothing in which we much excelled the civilizations of the ancient world. They cooked, they spun, they wove, in linen, in wool, in silk; they manufactured silver and gold and iron; they carved the 
precious stones; so that I think it is safe to say that the common life of our fathers was not unlike that of thousands of years gone by, if, indeed, at its best it ever attained some of the refinements of the fortunate people who lived about the Mediterranean Sea,

Nor was the intellectual world of our fathers very different. The vast majority of educated folk were busy thinking over the thoughts of the past, puzzling over the problems raised by Socrates and Plato and Paul; concerned with that interpretation of the world handed to our Teutonic or British ancestors by missionaries, and especially revived by the ferment of the Reformation. In my own boyhood days we were still discussing the freedom of the will, the divine sanction of slavery, modes of baptism, and the possibility of mental somnolence, under the query, "Does the mind sleep?"

Remember, I am not criticising the employments, intellectual or other, of the generation past; not at all : I mean only to say that we have within fifty years, perhaps without knowing it, passed through a new intellectual renaissance, perhaps the most notable in the history of the race, comparable only to the revival at the close of the middle ages. We are confronted by a different view of the world; we see the whole world differently; man's thought about himself and the universe can never again be the same, and new problems have filled the entire horizon of our philosophy; if not to the exclusion of the old discussions, at least to their profoundest modification. New thoughts, new purposes, new plans have taken possession of men's minds and all old things are changed, or at least seem to have passed away forever. 
Now many of these new concepts, and things which occupy so much of daily thought, have found place, naturally enough, in the curricula of our schools ; tentatively at first, then more aggressively until to-day the youth who seeks an education finds himself confronted by the learning of the century in every possible detail, until, in fact, instead of a definite course which he may complete in four definite years, he sees stretching away, course upon course to the last horizon of human research, where no human lifetime since the age of Methusela would suffice to compass it all.

Nor is this all: the old system of apprenticeship having fallen by the way, our handicrafts are in confusion. There has come about a centralization. Manufacture of every sort is performed in great shops. The butcher, the baker, the candle-stick-maker have lost each and every one his trade. Great plants, maintained by importation of skilled labor, have almost eliminated the old-time trades of cooper, wagon-maker, shoe-maker; and the American youth grows up, not only ignorant of, but actually out of touch with, all those fine old arts which ever heretofore formed a delightful, healthful, and withal honorable employment for hand and brain.

To meet the difficulty the schools are summoned to teach the arts and erafts. In the common school, provision must be made for quasi-carpentry under the guise of manual training, and even the university applies its science, has benches and forges. Even the old-fashioned arts of the field are made the subject of lessons and lectures, and our very recreations, games, and sports, play their part in the university or college curriculum where 
every conceivable topic of possible human interest, from things Platonic to play as tonic, from Bosporus to bos taurus, has distinctive recognition at the faculty board. Apollo and his muses nine are daily jostled, nay, are hard pressed, by Hercules with his club, - his base-ball club!

In the presence of such an overwhelming display of pabulum, intellectual or other, the American youth, nor less his more anxious father, must stand more or less appalled. He is bidden to a feast where the tables do not simply groan with their burden, they have broken completely down. Everything is in a heap on the same terrestrial level and the youth is bidden help himself; prescribed regimen or diet there is none.

Now again, I am not criticising methods, subjects, or schools. All this has come about naturally: we older people have seen it all : the confusion is a response to the transformation of the age. Educators would meet the necessities of the time, the needs of every individual, as each individual may feel his need; and the gates of the temple of knowledge are not only open, they are off their hinges, and the priests of the sanctuary have all taken to the field.

Notwithstanding all this, notwithstanding the absolutely unrestricted election now open to all seekers after truth, there are, as wise men know, certain very definite limitations set by the nature of the case and these may perhaps even yet guide us to a right appreciation of what is worth while in education.

In the first place, the pupil himself, the subject of all our care, prevision, and provision, has not changed. 
Changing philosophy, the discovery of electricity in its manifold service, even the autocar with its horn, has not changed in one iota the nature of the boy. His body is still made up of the usual organs: he must be warmed and fed: he still seeks amusement and play: he is still a creature of passion, he loves, he hopes, he fears: he has but five senses, gateways by which the world may reach him at all: he has but a few years of happy, careless morning, then a few more of toil and burden and disappointment, mingled sorrow and joy; then a few more of quiescence and waiting and the lights grow dim, the play is out and all the noisy confusion and eagerness of the world shall disturb him no more forever. The nature of man has in no wise changed.

In the second place, the problem varies not. There is only a little that education however fortunate, is competent to do for any man. No education can engraft upon the boy the wisdom of his father, to say nothing of the learning and wisdom of his age. "Knowledge comes, but wisdom lingers," and wisdom is still "the principal thing." No system of training ever devised can make a man wise; no system save that of Nature, herself, and Nature's system demands the whole of a human life, and even then is, I am sure, not always successful. No, there is only a little that education can do for any youth: it can help him a little to adjust himself to his surroundings, to the age in which he lives; it can suggest to him the pathway of happiness as indicated by all human experience, but this is all; there is really in all education, wherever or however offered, nothing different from this. It is still true in the world of wisdom: "No 
man can save his brother or give his soul a ransom for him." Our more abundant courses of study, our wider knowledge, may give more varied opportunity, may meet more surely the individual taste; but the root of the matter must still be the same; the essentials of what any course of training, not professional, does for a man, will always remain what they have always been; they will make for his development as a healthful, reasonable, selfrespecting, reverent, and in so far fortunate denizen of the world.

You will note that I say training not professional. Professional training is special and aims to make a man competent in one single particular. We all know what this means, and this need not now be considered: but the education that is universal, that should be accessible in all our schools, that has for its sole and single object the fitting of our youth for fortunate, peaceful living in a civilized state, such education is in no sense professional, altho it may be that professional studies, whether of law, or medicine, or carpentry, or agriculture, may contribute to its simpler purposes. Let us see now very briefly what factors shall enter in as essential to that universal training which varies not.

In the first place, as the very foundation of all fortunate living in this world, I name what may be termed, for lack of better terminology, the science of health. The very first essential in all education is the knowledge of what makes and keeps our bodily cleanliness and health. No extended course of study, no wealth of equipment, no palatial buildings or machinery can release from this physical obligation. Here no doubt Nature will be to us 
our most efficient teacher. But we have long since ceased to heed Nature. We no longer live natural lives. We are living in ways in the highest degree unnatural and artificial. We shut ourselves in houses. We wear strange swathings and bandages that we call clothing. We eat all sorts of artificial food; and, worse than all, that which we have not before us in actual presentment as physical fact, we build up in imagination; we excite ourselves with vain longings for things not yet possessed; we scare ourselves with dreams and visions, and torture ourselves or entice ourselves with ills or pleasures that exist not;

"We look before and after and pine for what is not And our sincerest laughter with true pain is fraught."

In fact, most of our individual sorrow in this world, if not all of it, is incident to the fact that while we have turned our backs upon Nature and are civilized, we are not yet enlightened. Nobody has to teach the wild deer or the prairie chicken how to be well; and our domestic animals would be equally fortunate did we let them alone. Our pristine ancestors must have been once as fine and free as their wild neighbors in the forests. On emerging from the woods a thousand years ago, they must have brought with them to their first contact with civilization a tremendous surplus of good health or they would never have come through those dreadful centuries of so-called Christian civilization, the centuries of the later middle ages. In fact we are even now as a people spending that inheritance, with plenty of indications, however, that its sources have begun at length to wane.

It is one of the essentials of education to learn to be well and happy; and though the sun of human know- 
ledge should be doubly as vast as now, and although the courses of study in university and college should display it all, still the man who would attempt it all but leave out the care of his bodily health, would be worse than the man who omits charity - worse than nothing. No scholar can hope in this day to help and bless his fellow men if he must be forever attending to his eyes or his stomach, or his ears, or some other piece of his machinery gone wrong. Ingersoll used to say that had he been making this world, he had made good health, and not disease, eatching. Ingersoll was not very observing. Good health is catching. Your competent physician, surgeon, minister, lawyer, is the man of health who carries with him in his own redounding energy and vigor the help that others need. He is radiant, and men are blessed who meet him. And you, young people, will go out from this college educated just in so far as your own good health enables you to enjoy your own life and to bring to men about you cheer, and patience, and power. Not many days since Bryn Mawr College awarded a prize to the member of the senior class who during her four-year course had shown in the highest degree "joyousness, courage, fortitude, and faithfulness." That prize is well founded. To show the qualities named indicates perennial good health, and the exhibition of such qualities is a mark of high educational attainment; for they are cultivable virtues all.

Closely associated with bodily health is mental health. and I suspect that one exists not without the other. There is no use disputing the matter; the dyspeptic, the epileptic, the nervous man can not for long bless or 
benefit his fellow men. As the Germans have it, a sick man is krank, a crank; it can not be otherwise. Whatever your theory of mind or soul, the only known medium of activity is this body of ours, and only as the instrument is clear and free can the thought be pure and sound and true. The reasons why the philosophies of the world are so absolutely futile, so contradictory in all their setting forth are two; first, the subject matter attempted transcends human knowledge; and, second, the philosophers have been more often poor invalids, often celibates, monks, and fathers of systems, but of nothing else. I believe it is safely stated that no piece of literature or philosophy worth the attention of the world has come from an abnormal man. ${ }^{1}$ You must be, first of all, human, and love humanity before you can portray or in any wise understand, the motives and passions of a human soul.

A second valuable element in education as I would present the matter this evening, is a knowledge of common English. No education to-day is of very much use that leaves a man ignorant of good English. Whether for one reason or another, English has become the imperial language of the world, and is likely to be more widely powerful and serviceable as the centuries go by. One-fifth of our race to-day speak English. In China alone do we find any one great body of people in larger numbers speaking another common tongue. But there are those now living who will see English spoken over the whole Chinese empire. Now think what this means. It

1 I do not say "gains the attention of the world;" that is another thing. Men read even Schopenhauer and Nietzsche! 
means that the highest attainments of human thought in art, in letters, in philosophy, are to be open to all men. Just in so far as light and inspiration ean find utterance and have found utterance in English speech, just so far will these reach in new pentecostal blessing the waiting nations of this world. Just as through the instrumentality of English letters, the wisdom of past and present, the best experience and hopes of men have come to you, just so in ever widening measure shall these things by the same agency come to increasing millions. Who shall not prize a possession, a gift like this? Fortunately for you, young people, it is the speech to which you are born; but let no man think himself educated who knows not how to use it with precision, correctness, and skill. Nearly all the really artistic contributions made by America thus far to the literature of the world, originate in New England. But in New England for two hundred years learning had her home in the manse, and men were students and scholars in English. Go to the great libraries of the eastern states, to Providence, for instance, and see the manuscripts in keeping there. Sermons, you say? Yes, sermons; but beautifully written; hundreds and hundreds of them, all in elegant English, in penmanship as if engraved; diseussing theological topies, no doubt, but scholarly to the last iota. These painstaking clergymen-scholars were the forerunners of Emerson and Lowell and Holmes, and made possible the whole New England school of literature. In our present sowing, I confess I see small promise of any similar future harvest.

Study English; study its masterpieces, the Bible, 
Shakespeare, the histories, the poets, not for information merely, not merely for the intellectual delight, inspiration and pleasure that these things so wonderfully afford, but that you may become adept, expert in the use of the most mighty instrument now at the service of the intellect of man!

A third essential, as it seems to me, in any man's edueation to-day is a knowledge of his own history. I mean, of course, history in a broad but after all, personal sense. It was the wise remark of a French philosopher that every man should know at least two things - qui il est, et où il est, who he is and where he is; that is, it behooves a man to know both where he is and what he is in this world-stream of change that we call time. Now the knowledge of history as I would have it at this moment, is not the mere perfunctory acquaintance with the recorded facts of days gone by; not the mere knowledge of the text-books, that Columbus, for instance, went traveling with three small vessels, the Niña, the Pinta, and the Santa Maria, or that General Grant fought the battles of the Wilderness, but an appreciative knowledge of the history that touches immediately you and me, that teaches us that we are to-day and now, ourselves, a definite part of history, that we are what we are and where we are, because of the facts of the past and that to the interpretation of these facts we this day are set.

History touches us on every hand. We live, for instance, in Delaware county; but why Delaware county? The name of your county brings you face to face with the history of England for a thousand years. Nay, there could be no county had there been no count, in 
French compte; no count, had not the Roman emperor been surrounded by attendants, comites, those who journeyed with him, in time the officers of his court, the governors of sections of his realm. And so the Roman emperors go marching up and down before us. County is not English; it stands for the old Teutonic shire; and so by whatever term you call the territory, the sheriff or shire reeve is, in English lands, lord of the situation to this day. And that is your history and mine.

This is just a glimpse of history as illustrating the conditions under which we live. Everything about us, all our institutions are historic; they are what they are for reason. Why do we have two chambers in our legislature? And why is one of those called a senate?

But these things are perhaps less important. We use many things because we have them; they come to us as part of our inheritance and we are less concerned as to their significance. Nay, we sometimes persist in retaining customs and institutions meaningless if not actually inconvenient. Some people actually advocate the abolition of the United States Senate: why not?

But this historical relation touches us more intimately still. We have in the past a personal, an individual interest which, when realized, may wonderfully aid in solving many of the problems of life. I have little sympathy with the thought of ancestry; possibly for good reasons; nevertheless there are many things in our personal history which we can never afford to forget. We are nearly all of us of Teutonic or Celtic origin. This means that we are by nature free. We are free- 
born. Again, we are the children of men who refusing the tyranny and oppression of Europe crossed the ocean to build for themselves new homes in a new land wherein dwelt liberty. From Ireland's perennial green, from the moors of England and the heather-clad hills of Scotland and the sand-girt forests of Germany, from the valleys of Rhine and Rhone, and the lilied meadows of France, our fathers came, singing their songs as the spirit gave them utterance. More than that, we are most of us the direct descendants of the pioneers of this prairie state; of men and women who again endured hardships for the sake of a wider, fuller, and freer life; men erect and strong, full of health and vigor and the joy of living, men without fear, the elect of the older commonwealths of this republic. These were our fathers. These built for us these homes, planted these pleasant groves, these fertile farms, nor less our churches, colleges, and schools; sacrificing comfort, wealth, labor, all, that their ideals might survive; hewing with their own hands the beams from the forest, the stone from the quarry, and with their own hands laying brick and mortar in the original building of such a college as this, that young people in thousands might learn the lessons of the past, the science of the hour, and be fitted to live righteous lives of intelligent citizenship for the coming years. We are the children of heroes thrice renowned, the heroes of the Reformation, the heroes of the Revolution, the heroes of the prairie; of freedom's battle through a thousand years; we are ennobled by all the story of the past, and none disputes our patent.

These faced the morning, the morning of a better day, 
and that better day is here. We shall know our history and feel its perpetual inspiration. Noblesse oblige. Such nobility puts us under obligations. We shall know our own history, at least so far as to see that languor and pessimism, and world-weariness, belong not to us nor to our race. Our shields are shields of expectation. No education is of much service which does not heighten a man's true self-respect; not self-conceit; that belongs to the uneducated, the ignoramus.

But historical studies should also establish in the heart of the youth respect for his fellow man. Here lies largely, as I take it, the educational value of linguistic study which is properly historic study where of any real value. The study of a foreign language simply introduces us to the knowledge of some other large section of our race from whose acquaintance we were otherwise, by the barriers of speech cut off. Only ignorant men despise their fellows. No scholar ever used the term Dutchman in derision. The Mexican peon calls all Americans gringos, "green-horns ;" 1 but we know that this is owing to a lack of information and to a curious national pride which is to us simply amusing; and so, as another of the things worth while in education, let us put a thorough knowledge of some foreign speech. This is not so much for convenience of intercourse, if it be a modern tongue, not for the sake of literature, even, but simply that we may yield to other men the respect which is their due. In all social intercourse, right behavior is based upon true recognition, and appreciation. It is the part of

1 The Century Dictionary says the derivation is probably from Griego, i. e., Greek. 
education to inculcate good manners. For the lack of good manners, nothing, absolutely nothing, can ever atone. It is well to know things; it is well to know our own history; it is well to have thorough self-respect; but no amount of accumulated pride of race or learning can excuse a boor. Courtesy is the delight of life; it is the glow of sunlight upon the fields of ripening grain, and goes on forever, adding to wealth the element of abiding beauty.

It will have been noticed that everything cited so far, as desirable in our systems of training, has reference to the individual man and his knowledge of himself as an individual; we may not however, even in this brief résumé omit reference to that other great field of human thought and interest which concerns the physical world. No man may deem himself educated, or even on the way to scholarship to-day, who does not know accurately some one of the many forms of physical science. This for several reasons; in the first place, the world about us is a very wonderful and glorious world, very well worth knowing, and to it we stand in most intimate relation; in the second place, our thought about this material world and our knowledge of it combine to give us our philosophy, our highest and most wonderful intellectual activity. Nay, the religion of the world, its faith, has in all the centuries been an expression of human science, ennobled and made credible, possible, more and more, as the enigma of the universe becomes legible through research. The highest thought in every century is an attempt to explain the world and its ongoings. Thousands of years ago men declared, "The 
works of the Lord are great, sought out of all them that have pleasure therein," and to-day all pure science is but an endeavor to describe the method of the working, the energizing, the becoming, the evolution of the universe as of some vast unfolding flower set by time's eternal river.

Again, as immediate sequence to what has just been said, it is worth while in your education to know the world-spirit, the $Z$ eitgeist, the intellectual attitude and atmosphere of the time in which you live. This varies from generation to generation. There are in each age, say in each century, certain intellectual conditions under which alone is possible, not thought only, but all setting forth of thought. Thus, the dominant intellectual note of the eighteenth century was religious scepticism as illustrated in the work of such a man as Voltaire; that of the nineteenth, the evolutionary interpretation of the variety of the living world. No man in either period could successfully put forth anything from his own literary or mental workshop, and ignore the electric intellectual conditions under which all thinking men of his time were living. Humanity seems able to concern itself with but one thing at a time and while interested in that, relates to that one, dominant, over-mastering note, all the minor strains of the concerto. I believe that our particular phase of the science-impulse is largely spent. Perhaps he who reviews the twentieth century as we here look back upon that just ended, may speak of sociology as affording to the world of thought its dominant tone and chord.

In any event, in all our educational efforts it is worth 
our best endeavor that we recognize the philosophic conditions under which we work, that we forecast the drift of thought, and that we so adjust ourselves as to take advantage of the ever larger and broader view by which the new cycle is ever certain "to shame the old."

Here then, is the place of all these wider institutions of learning where college ranks against college, and foundations and lectures and courses of study are multiplied in ever increasing complexity. Here is the place of the great university. While it may primarily meet the simple demands of the simpler training I have already sketched, and while it certainly must afford to the professional man, the physician, the lawyer, the engineer, the training he needs for his special business in the world, yet in a broader and finer sense the great university is set to represent the intellectual world, to exhibit not its attainments only, but its spirit; not merely to foster learning and conserve it, but to widen the limits of human knowledge in every field, display each new attainment, and so maintain that noble intellectual ferment which carries the race forward, albeit but a single step at a time, to ever clearer and better things. In the living universities of the world the spirit of the times is not only developed, it is forever made manifest, sent forth, and the atmosphere of these greater intellectual centers becomes sooner or later the familiar air of every humblest study. To a university as a great mart, all wares are brought; new caravans are continually arriving and the confusion not infrequently is great; but the customer may select his own, and every one may find the object of his quest. Here is the meeting place 
of the intellectual world, and by visiting these halls, these vast libraries, collections of art and nature, and all products of human wisdom, the student is spared a world-journey and finds at his hand the best that every age affords. Such an institution is to be used as men and women use an encyclopedia; there should be frequent supplementary volumes; now and then a new edition, and a very liberal index.

Lastly, let us never forget that out of all educational training of every kind and wherever offered, there comes one superlative product, the crowning achievement of all attainments, blending these to purport, to purpose, to efficiency and accomplishment; this ultimate sublime result we reckon character; the total aggregate of all those powers, and tastes, and passions, perceptions, principles which make up the individual enlightened man. Through all the course of his school-training the student is brought face to face with ideals, the highest dreamed of, by the best and purest of the race; he learns to estimate value in units that may not be weighed in a balance with silver nor measured in ounces of gold; he learns to love that which is beautiful and pure in art, in literature, in life and -

\footnotetext{
. . . . . "whosoe'er in youth,

Hath felt his soul to such delights give way,

Shall feel congenial stirrings late and long."
}

"Like to that soul, art thou, which thou dost comprehend," the proverb runs; and to put the youthful spirit in fair and living contact with the precious garnered ideals of all the race and thus beget in him a character which shall make the hero, the saint, the scholar live 
again,- this is not only a thing worth while, it is the essential of education, past, present, and future.

Now it does not take much of a roof to cover possibilities such as are here suggested. Our fathers knew this well, and we their children should not forget it, nor be tempted to think that large endowments, palatial structures, or the refinements purchasable by wealth can ever insure the glory that we seek. All these are beautiful, they make for the convenience, the comfort, the stimulus of thousands; but the intellectual life is still the same sweet, precious, simple thing it was when Christ saw the lilies on the field, or Socrates talked beneath the plane tree on Ilissus' banks. Thundering mills, roaring engines, and hissing pipes grind out and deliver the flour that feeds the nations of the world, but the flour itself is shaped in the tender blades, in silent fields, beneath the unpurchased rays of the blessed sun, and the soft ministrations of the dew and rain. Even the kingdom of God cometh not of observation. The things worth while in all our schools are those not seen; the quiet purpose, the manifest high appreciation of that the world knows not, the association day by day with agencies and forces that make for purity and love and faith, for the world ideal, to which perchance we never may attain, but which no less shall be forever the high habitation, the sacred fond retreat of every noblest soul.

Nothing is more encouraging in these commencement days in all our schools than to note how more and more the world is coming to an appreciation of these high values for which the schools have stood. More and more the world discovers how absolutely priceless is the con- 
tented spirit, the attitude of mind that comes with knowledge. Vast fortunes are to their owners useless; but every man at this moment on whom the conditions of our time have laid the burden of riches, seeks, if possibly he may find, the shrine of learning, that he may leave at that altar the wealth that profits him not, but which he believes can bring to other men and other hearts the real satisfaction of our soul's desire. Is it not wonderful! The things that really count in all our education, as in human life, are inexpensive but eternal things, and learning's crown is still, as ever, wrought in simple leaves! 


\section{CULTURE AND THE STATE}

Very welcome indeed to your speaker is the opportunity and privilege of this hour. To be summoned by one's Alma Mater to any position of privilege is an honor that may well stir his best enthusiasm and endeavor; there is nothing finer; your speaker knows it and is grateful.

But to stand before these young people, this class of 1915 , to speak to them and for them, to voice the congratulations and felicitations of this glad season, in presence of proud parents, happy friends, and seemingly supreme accomplishment, of sunshine and roses and all things of beauty and of promise - this, I say, touches your speaker with a sympathy, a pathos, an appreciation of all that wells up in the human heart, and really makes the honor of the moment, the program, the titled and stately pageant of these older people, a thing of altogether less concern.

Yours, young people, is this day and hour; long on the creeping calendar of youth have you waited for its coming, and a stranger now shall not intermingle with its joy. Your speaker is as one who has long traveled on the road you this day enter. He has been called back from far down the way, perchance to tell you how the travel seems - its gladness, its hardness, if such there be; its arbors of refreshment, its opportunities and rewards.

But these fresh aspiring spirits may not be cheated 
by such a dolorous tale. They are not here for autobiography, pleasing form of fiction though that be. They are here for themselves, eager this morning for their own, for the experience of life to which they realize themselves justly entitled; and they care for no argument save as it relates directly to the present moment.

It is not intended to chill in any way such exultation; and yet, if we are the wise men we believe ourselves to be, we shall, I am sure, find added gratification if we study a little the meaning of all that has held us willing captives for a while, and so made possible our present emancipation.

The education of a boy, in school or out of it, may proceed in any one of four directions. It may concern simply his physical well-being, teach him to take care of himself, his health and life, how manfully to meet the world; it may teach him how to make a living, in trade, profession, or vocation; it may teach him how rightly to use the world, by awakening in him the spirit of fine perception of beauty, an admiration of all that is high and noble; and lastly, it may rouse in him a spirit of reverence and appreciation of the unfathomed mystery that shuts us in. In other words, education may be either physical, and look to bodily strength; or vocational, for business; or cultural, for culture; or religious, for faith and duty.

In this present argument the third alone may claim attention; by no means, however, without presupposing the other three; and it is proposed to show that culture, which is in danger to-day of being, at least, less appreciated, is not only a legitimate outcome of all training, 
but is of supreme practical importance and so of high value to our social and political life.

The subject proposed sometimes makes less appeal to men. Loud objections to colleges and culture are heard betimes; in short, it is notorious that all our colleges and universities are just now under severest scrutiny and criticism, at the hands of friends. The University of Wisconsin, for example, and the whole State, are torn into factions, in such fashion that years will hardly suffice to restore a condition of further progress and power. Every college in the country is sure to be called to account; colleges are declared not practical, or, judged by their product, even vicious; it is said that they serve neither the citizen nor the state; that they are a waste of time; that they teach nothing useful; that the boy never does anything until he gets away; and so on.

Now colleges of old were set for what we term culture; and if present objections hold, the case is bad enough. We are indeed wasting both time and money; and lovers of their fellowmen should immediately face about and turn their efforts to some more practical employ. The problem is of serious import. We can not afford to make mistakes. The state is the one terrestrial thing for which we live; to it all our loyalty goes out; and if in any way our colleges are less serviceable to the great republic, to the commonwealth, or even to the individual citizen, we should know it, submit the case to the great "committee on retrenchment and reform," and do something better. Perhaps we may see the situation more clearly if we study for a little just what is meant 
by culture, what is proposed. Then we may understand its bearing upon our more public life.

In the first place, then, let us define, if we can, just what we mean by culture.

You who have been affecting the classics know, of course, that our present use of the word is entirely a figure of speech. Culture, to start with, meant the care and development of a plant. This significance still lingers in agriculture, the cultivation of the field - that is, of what grows there-, horticulture, the tillage of the hort-yard, or orchard, as we say, and so on. Thousands of years ago men found that if they took a little care of a plant, gave it a good place on which to grow, with plenty of air and sunshine and water, the plant greatly changed, offered new characters, or at least new phases of the old : the smooth-leafed wild mustard of Europe, on cultivation, took on the form of cabbage, became a cabbage-head, in fact; the green, tough fruit of a Persian shrub became a peach; the sour crab, an apple; the wild grain, wheat; and so on; all this thousands of years before men had ever written a word. Small brown men, as I think, away back yonder in the forgotten years, in the childhood of humanity, made wonderful discoveries; they discovered the culture of plants. So it happened that when at last men did begin to think and to write, the culture of plants had long been familiar as to you and to me.

As compared with the story of the plants, Cicero was a modern. He looked out upon a civilized world; and, full of genius and wit and all accomplishment as he was, it occurred to him to compare the mental experiences of 
men with the history of the plant; and so the famous orator flashed all the mystery and the beauty of those natural, visible processes among the plants into the richness of one fine metaphor, "Cultura animi philosphia est" - philosophy is the culture of the soul!

By philosophy in this case Cicero refers, of course, to all the phases of intellectual activity in which the men of his time indulged. He had before him all Greek literature, Greek art, all the wisdom of the Egyptians; all the science of the ancient world; the deep things of Aristotle, Thales, and Pythagoras; and it occurred to him that by bringing all these things into contact with our mental powers, effects comparable to those seen in the vegetable world, out in the fields, might well be expected. Cicero evidently thought the thing practicable; the question for us to decide is : if practicable, is it also practical ? Is it worth our while?

It is evident that if we wish to improve to our greater pleasure the plants with which we have to do, we must cultivate them; and so among the generations of men, Cicero would intimate; if we would have olives and apples and peaches, and daisies, and even cabbage-heads, and not mere cabbages, we must apply definite processes and principles of culture, somewhat as these obtain in the physical world.

No figure, of course, may be more than illustrative; nevertheless, that involved in our present use of the word culture is unusually far-reaching in application. It is more than illustrative; it is illuminative. Let us compare a little physical fact and mental accomplishment.

In the first place, as a botanist I know not a single 
plant which may not be susceptible to the influences of culture. Of course we have not attempted them all; indeed, we have tried extremely few, but these in variety sufficiently to establish the principle. Of course, our work in recent times has been simply to extend the work of our far-away predecessors, who first sowed seeds and made the astounding discovery that, "whatsoever a man soweth, that shall he also reap." Men applied the principle by sowing what they preferred, and that alone; and the marvelous fact is, that only within the last twenty-five or thirty years have we begun in our laboratories and upon our experiment farms to do just that same thing. And yet we undertake to fill the world with the noise of our discoveries and our accomplishments!

So I return to the statement; not a single plant but might lend itself to culture's suggesting guidance. You may say nothing can be done with thistles, cockle-burs, and darnel. This is not entirely a story in botany, or I might show what has been done with these very plants, that what they are is the result of Nature's tillage, and is by her approved; - we may prefer something else. But when Mr. Burbank takes the desert cactus, almost the fiercest plant we know, and converts it into the inoffensive wealth of the meadow, into forage for cattle, into delicacies for the table, pickles, confections, and preserves, surely no plant may be put down as hopeless.

To what limit may culture not reach, or where are then the bounds of its applicability? Apparently in the natural, physical world, bounds there are none. But for us, in our effort to deal with any particular plant, there is a limitation, just one that I know. Nature's long tuition 
in the millenia of life's past inhibits our hasty effort. Here it is time that is long, and art that is short. What by indefinite time has been brought to pass, that we may not, in our brief years, recall. We may go forward; the way is long, and leads not to Tipperary. Still abides the profound though simple dictum: "Of thorns men do not gather figs, nor of a bramble-bush gather they grapes."

We may by cultivation make a better thorn, but we may not make it a fig-tree: we may change the bramble, lead it on to all forms of bramble-hood, but never to identity with the grape. The application in our efforts at human culture is easy; if we succeed we shall not hope to change identity; form and expression only are subject to our behest. John Jones will still be Jones, but he will be a cultured John; William Patterson will be Patterson still, but a Patterson transformed!

But let us see something, if we may, of the manner in which Nature has, in all the course of ages, brought our plants to the condition in which we find them. Her methods of culture may be at least suggestive, for that ancient dame is always consistent with herself and we are still her children. Whatever else is true, let us be sure that Nature's methods are in general direct, and right, and simple; in general slow and quiet, but persistent.

In our attempt to name Nature's all-compelling school, we say environment. From grade to grade she leads along, by varying environment. The surface of the planet changes, its atmospheric relations, climatic conditions change. Mountains rise to touch the clouds of heaven, and sink again to the general level. Fertile areas 
are shut off from rain and become a desert. The planet changes. But all these changes are slow, how very slow! and the plants perceive no change; instead, they become absolutely transformed, become used to new conditions; so that at length we have the richness of variety that we are only now beginning a little to understand. Heredity is to-day the problem of natural science. We do not solve it: we are finding only the pathway along which its impulse moves. It is difficult; small wonder. What we see, the present; not the ultimate; the unfinished product of Nature's culture-methods, operating through ten thousand thousand generations!

The physical conditions of this world, then, the conditions amid which life is called to act, change, change all the time; generally slowly, but at length definitely and appreciably; and life, plants, animals, have learned to respond. Were it not so, all our effort would be vain. Nature began the scheme of culture, and in all we do in garden and field, we are but following her cue. We change the conditions under which the plant grows, and the plant changes. Shakespeare knew this very well. Read act iv, scene iv, of $\boldsymbol{A}$ Winter's Tale if you would understand what four hundred years ago men knew of plant-culture.

Precisely as with plants, so it is with our human tillage. We change conditions and all changes. Monmouth College brings from their various far-scattered homes these eager, growing youth. She changes their environment. She brings them into a new atmosphere, an atmosphere of scholarship, where learning is the only value, wisdom the only sunshine, the encomium of good and 
wise men the immediate purpose, the approval of the great and good of every century the supreme reward; to match the self-sacrifice, the devotion of men who live for others, the sole ambition. She brings them in presence of new and wonderful scenes, truths which stimulate reason, quicken the imagination, the very wine and the bread of intellectual life, and everything is changed; ideals, intentions are changed; values are changing; the world is changed; henceforth none other light is sweet, none other air can kindle for these young men the fires of enthusiasm. They have found a different universe and they know not how!

It appears that it does not take much to feed a plant. The green, growing thing almost manufactures its own food as it goes along. The plant assimilates, we say; we do not know just what it really does; that is quite another thing; but the plant assimilates, i.e., makes over to itself, like to itself, the pabulum inorganic just before it. The dead stuff becomes living stuff. Mystery of mysteries! The thing goes on before us all the time; every June day, with a perfect roar, as of Niagara, on these glorious valley plains, in these wondrous gardens, could we only see it and hear it! No doubt of the fact: tons and tons of accomplishment in yon green field even as we speak. Marvel of marvels! Culture or no culture, only think of it! A little water, the atmosphere with its vital oxygen, a little $\mathrm{CO}_{2}$, a few earthy salts, and lo! the sheen of leaf, the strength of stem, the splendor and perfume of flower, the glory of fruit.

And so in the culture of the souls of men, such are in fact the tremendous possibilities; for figurative though 
our speech may be, we are dealing now with something much more than a figure. The ways of human culture are the ways of nature with the roses. The youthful mind appropriates, assimilates in strangest but most positive fashion; does not borrow, does not much accumulate fact or statement; actually assimilates and grows! You place before young people, in the atmosphere just described, literature, history, science, art, labor, any skill of brain or hand; you show these things; you awaken appetite, interest, and away they go! The intellectual life takes care of itself, just as does the life of the plant. The far fields of history, for example, widen till the lad can see naught else. Himself wins Marathon and Salamis. 'Tis he that walks at sunrise by the creeping Nile and sees the earliest ray pick out the golden glory recorded long ago upon the pyramid's sloping sides. He knows the secret of that sad stone face they call the Sphinx, watching for the morning; he walks with Pericles among the marble glories of that priceless Athenian hill; he traces, with busy finger, wall succeeding wall that vainly shut in the majesty of the seven hills; he sees long roads that run to the ends of the earth; he, reading the opening pages of pictorial Gibbon, watches the marching files of the imperial guard as with purple banners they bear to all the world the peace of Rome.

You show literature to the careless boys; some of them will plunge into her fascinating tomes; philosophy, poetry, story, the languages of man. Here is a dream-world, unvexed by noise or tumult or war's alarm, an exhibit of real culture, not kultur. The student learns how barbarism, alike of pagan and Christian centuries, sweeps 
from all the hills and plains the clustered monuments of art, sends to oblivion whole nations and tribes of men, while literature somehow survives, and tells, to all who read, the tale of human hope and human sorrow. "Cities rise and sink like bubbles on the water," but somehow the dreams of men remain.

Remember, only real literature persists; not foolishness. The graffiti abide because they mar the masterpiece; but the graffiti are naught. Only persistent real literature can meet the purposes of culture. The plant must have real food. You may not feed a plant on sawdust or pine shavings: no more shall you feed a boy's mind on shot-rubbish, ashes, or rottenness of any sort, though assembled verily as "The Eyes of the World."

Take another sort of intellectual food. Take the facts and theories of natural science, of physies or mathematics. These shall stir ambition and rouse an interest perhaps all too keen. It is sometimes thought that the history of days gone by is of less import, as too remote from the ordinary interests and concepts of the life of this day. But for the normal youth the source of all that comes makes no slightest difference. The plant cares no whit in what glacier, or mill of the gods, was ground the earth-flour on which it feeds. Old things, new things, are alike to plant and to boy; they are all new to that which begins to live!

There is no doubt of the fascination of recent science, especially of the so-called applied sciences; these, as nothing else, shall quicken the dormant powers of youth. Here is something "doing"; the boy is interested; perhaps not so much in science as in invention, in the work 
of his own hands, ere ever other forms of education be once thought of; in electric lamp and train, in auto, aeroplane, the implements of the kitchen, the very toys that move in wonder. Oh, yes; science shall serve! But after all, is this science? If so, is it a means of grace and culture? It is applied science; it does much, no doubt; for all activity contributes; such gifts prepare the way. But does it meet, after all, the highest needs of the life we are seeking here to-day? Plants indeed will grow with electric light, but they need the light of a larger luminary. Rods of steel may give the plant support, but the oak and pine need them not. No; these gifts of science and their use, invaluable as these things are, are not just now in question; may not, as it seems to me, be reckoned as of highest cultural value; to so estimate were unfair to science herself, whose power and fascination and inspiration lie deeper far, and higher far.

Serviceable as all invention and industry may appear, the culture here discussed lies rather in pure science, intellectual activity, the intellectual research and triumph which has made possible applied science, the brilliancy and the accomplishment of our age. The wonderful visions of Lavoisier, of Crookes, of Thompson, of Mme. Curie, and such explorers, revealing to us the constitution of matter, the make-up of the worlds - these constitute the real facts of physical science, these the finest pabulum of the inquiring soul. Faraday's lines or streams of force end in the wireless messages flitting perhaps this moment above our heads. Every boy wants a wireless station, indeed; but better still, every normal youth wishes that he could understand it! The science, 
where the intellect really has play, lies in the world invisible, where molecules and atoms have been wont to move.

"The rushing metamorphosis,

Dissolving all that fixture is,

Melts things that be to things that seem

And solid nature to a dream."

Nay; the atoms themselves are gone. Ions and electrons, mere disembodied units of energy, are before us now, bringing analysis and even system to the assumedly indivisible; and we venture to speak of the nucleus of the hydrogen atom, hitherto the most minute of things conceived, and even to assert that that now reckoned the most minutest thing, visible only to the eye of the intellect, as in its quest it wanders beyond the dominion of the seen, and studies in the "light that never was on sea or land," - that that minutest nucleus has, as things electric go, a definite algebraic sign! If anything may quicken the spirit that is in us, surely here is stimulus refined. On what gossamer threads in heedless safety imagination runs to bridge its dizzy way far through worlds unlimited, unvisited, unviewed, yet real as the universe itself !

According to quoted dictum of Matthew Arnold, culture in the active sense is the quest of sweetness and light; in other words, it is the quest of beauty, that which pleases, and wisdom, that which guides. How does the scientific speculation of the day meet both requirements, at once charming us, and leading to more and more certain knowledge of the truth; pragmatic truth, growing, changing in the indefinite grandeur of its simple splendor! 
Precisely in the same way, did time permit, we might discover art, the skill of painter, architect, sculptor, weaver; the industry of bench or forge or field, cultural every one; each of these things may stir the youthful soul. The ring of the anvil, the hum of the saw, the whistle of the great smoothing-plane along the straightening edge of boards, even the almost inaudible rustling of the plough as it passes through the glebe - all these things are music to the intellectual ear. No; not all these things - oh no! - but any one of them, may afford food for the spirit and so rouse it to that quickened sense of light which is culture. They are all filled with meaning; they tell of fact accomplished, of plan, and thought, and purpose; of beauty that pleases, of wisdom that guides. Simple things are these, but like the great things of science, for that very reason, cultural, assimilable to the human spirit.

But now having seen something, very little, I admit, of the food-supply which our age offers to the minds of aspiring and ingenious youth, it is time we turned to examine for a little the outcome, to see, if we may, what comes of all this; in fine, to learn what may be the possible value of such intellectual exercise and experience when brought back to contact with our every-day world; when, leaving the confines of school-room and campus, we walk the ordinary ways of men and meet the real problems that vex our individual and social life. How can the culture which the schools afford make the individual who has felt its touch, more fit for civic duty and accomplishment? This culture, found in college, is said to be, let us recall, absolutely without practical value. 
It may be noted in passing, that if the boy comes out with a definite career before him, no one then seems inclined to question the value of his training. If he turn out a lawyer, a minister, a scholar, a teacher, or if he apply his knowledge in some evident, visible way, as an engineer, or a contractor, or an inventor, or musician, and especially if he greatly win, if he "makes good," as men say - then the work of the college is of value; wisdom is justified of her children.

But I have been pleading for something else, for pure science, for the spirit of learning, for the very beauty of labor, for a resultant attitude of mind, for character; and I must now defend the thesis, that this viewless thing, this mere way of looking at things, is yet of value to the state.

The happiness of what we call the state, its good fortune, is nothing else than the happiness of its individual citizens. If every citizen, if all citizens are happy and fortunate, then the state is successful, realizes, in so far, its purpose. If culture, then, does no more than contribute to the happiness of its fortunate possessors, it is justified and so far contributes to the general good. That cultured men are happier men than they would otherwise be, goes without saying. There are no pleasures like intellectual pleasures; there is no joy like the joy of knowing; and the number of citizens realizing this in personal experience should be as great as possible.

But it is urged that men from cultural colleges, even if happier, are useless; they are dreamers; given to intellectual concerns; they are incapable of dealing with practical affairs. Let us omit the dreams, for a little, and get this objection out of our way. 
Culture tends, it is believed, to injure the state by enlarging the army of the inefficient.

It is admitted, of course, that cultural education, whatever its basis, may not always succeed; does not always furnish forth a man of service. This for two good reasons : first, notwithstanding venerated authority, all men are not created equal. There is diversity of gift. Second, the influence of the teacher in the college is not the only factor in determining individual activity. Conditions of wealth or poverty, health, environment, early surroundings and education, parental care - all these things affect, as they do other people, men who enjoy opportunities for culture. Intellectual training not infrequently corrects such handicaps to individual success; but not always. There is no culture of the plant unless the plant is alive; it must respond ; and so there is no intellectual culture without effort on the part of the subject. Culture should make for activity, and I am prepared to show that the man of culture is not only ready to work along the lines, unremunerative generally, in which he has at college found pleasant employ; but he is perfectly ready to join the vast industrial army of the commonwealth, and to do work with his hands, directly. Hopkinson Smith was a lighthouse builder. Some of the most cultured men I have known have worked at the bench, designing and building beautiful furniture, houses, wheels, etc. Some have been carpenters, printers, weavers, gardeners, farmers. It is simply idle, therefore, to say that culture and labor do not go together: the wide school of those who follow William Morris rise up to confute forever such a notion. 
In the May Atlantic Monthly Mr. Judy tells, in a delightful paper, how he and his wife bring all the culture of the schools and seventeen years' experience in parish work besides, to meet the problems of a farm, that type of industry which most people think to approach without intellectual effort of any sort, and which men believe, or pretend to believe, is entirely remote from culture and the way of the finest exercise of human skill.

In a great college that I chance to know, where are some three thousand students, probably forty per cent, year by year, labor with their hands to support themselves, in whole or in part. Labor is sweet, its products are beautiful and pleasant things; itself is culture, when rightly used, the intellect touches it with beauty as sunlight gilds the furrowed field, and every man of culture daily breathes the petition of the old-time poet: "And let the beauty of the Lord our God be upon us ; and establish Thou the work of our hands upon us; yea, the work of our hands, establish Thou it."

The fact remains that the whole aim of culture is service. As Arnold puts it, it is to make beauty and wisdom prevail. Culture would bring gifts to men, show them how to appreciate the good that is in life, and to use that which makes for real happiness and health. Who are the men who are serving their fellows directly this day in all forms of social effort? They are, like our own McClaughry, to a man, men of refinement, scholarship, culture; men who bring to bear the best that the schools can give in helping the state to care for its citizens, to govern them justly, skillfully, and magnanimously; to deliver the poor and the needy from robbery and 
oppression, and to save little children and their mothers from sorrow and want. Who are the men who plan your fine streets, secure for all the people your public parks, your avenues, the play-ground for the children of the poor? Who are all these? These are men of culture, men who have ideals, who have dreams, if you please, and who make their dreams come true; not great moneymakers, perchance, but men who can persuade even wealth to service, and so, without taxation, bring vast private fortune to the aid of every good and glorious cause. Nay, who is the man who at this moment in the name of common humanity and in defense of the citizens of the republic denounces the murder of innocent women and children and calls warring nations to account? Who is this man? A man of culture, a college professor, a student of history, a scholar, but a courageous and manly man, whom the nation rises to honor and applaud with unanimity unknown for fifty years. Culture, the most impractical sort of culture, as men sometimes assert, does somehow serve and serve tremendously in the great problems which affect mankind.

But culture not only contributes to the satisfaction of individual life and to the sanity and service of the community at large, but it serves the world in still another way, and this perhaps the most remarkable and important of all. Culture sets before men certain standards of value which, in so far as they are seen, change and temper the whole course of human living. Here I think is to be found the explanation of most of the criticism by which cultural education has been and to-day is so fiercely assailed. 
For the ordinary man, value is a thing easily defined. $\mathrm{He}$ knows what value is, for, as he says, he knows the value of everything about him. True, the dictionaries take columns to define the various meanings of that one word, value; but that is because the dictionaries are not practical: any boy on the street will tell you that the value of anything is "what you can get for it." All value is referable to exchange, to commerce, and we are face to face with the so-called "commercial spirit" of the time.

Small wonder that this is so. We have as a people become suddenly rich, and the penalties of wealth are upon us. Within twenty years the wealth of these valley states has increased two or three hundred per cent. In Iowa every fourth family owns an automobile, the proportion greatest in the country, where almost every farmer has such a machine. As a result the whole social fabric has been thrown out of joint. Almost constantly, day and night, one-fourth of our population, in fine weather, is speeding along our level prairie highways, while the other three-fourths are excitedly looking on, waiting to attain the same blissful state of mobility - or automobility. All other interests are lost to view. Home life, neighborhood life, rural church and school, everything is forgotten. The only thing worth seeking in this world is money enough to keep an auto. Fortunately, Mr. Ford has come to the relief of his fellow-countrymen in the matter of price, and the world is on satisfactory wheels.

Now the only way to counteract the present craze, the only way to save the republic, as it seems to me, from 
the destruction which has, in all time, come with wealth, upon every nation, so far, in the world, is, if possible, to maintain in our population a leaven of culture, a sufficient number of men and women who have found for value another meaning than that which may be expressed in money or autos. He was a wise farmer who was not so much concerned in buying for his son a car, as he was in learning where it would take the lad once he got into it. That is it, that is it! What shall be the end of the ride? Of what possible use is a touring car if it takes a man to destruction; or if, through ignorance, the unfortunate owner have no slightest inkling where he is going? It is bad enough to remain at home and be ignorant; but to come suddenly to wealth, to have means to see the splendor of the world, to pass the flowery fields, the flowing hills, the treasured cities, as in a flitting car, and be all unconscious of their meaning or their beauty, to have all the world clamoring for recognition and still to sit in a limousine and be ignorant - this for a sentient soul must approach the lowest level of personal disgust and disappointment. There is no use disputing it; men can never in this world be satisfied by what they merely have.

The moralist, the teacher, the preacher, can not too much proclaim the absolute futility of wealth to meet the individual need, the needs of the human spirit. They tell us all the time that:

“E'en bliss and joy that may beget

A sense of faith in things we see,

Is like a glorious garden set

Down by the sea. 
"They flourish till some night wind blows

The swelling tide across the land,

And buries tulip, pink, and rose

In salt and sand.

" Then though the slow retreating tide

Withdraw its foam and crawling things,

Yet where the wandering wave hath sighed

No fresh bloom springs.",

The rich man, in his proverbial search for health, not to say joy, drinks his cup of postum and eats the crumbs of sorrow which, for a consideration, thrifty Battle Creek prepares for his abstemious breakfast; and all his wealth avails him not. It is trite : but look at this. Only a few days ago a few score aged men were marching along our city street. Before them went the banner of the republic, and each bore as his badge of honor a copper button worth a penny. But the wealth of Golconda may not buy that button and the right to wear it!

Value, value; do we not begin to see that in themselves dollars have no value? Did you ever see the copper button set with diamonds? How should in such a place the Kohinoor lose its lustre, and the copper badge blush in sheer humiliation and disgrace! Only intelligence, accomplishment, has value, and culture scorns the evidence of wealth, save as it may serve the purposes of wisdom. Wealth can never be, as culture always may be, an end unto itself.

The fact remains, as was said long ago, culture aims to "raise the intellectual tone of society, to refine public taste, to facilitate the exercise of political power." If our colleges and universities fail to impart such culture, 
if they do not raise the tone of society, or refine the public taste, if they do not contribute all the time to the right direction of our democratic power, it is either that they have departed from their own high purpose, or that youth have ceased to recognize the excellency of that beauty and power which the ages have approved. It may be, as some would show, that a college graduate is sometimes absolutely illiterate. If so, he has never been a student; he entered college a boor or street-gamin, and has proudly held his own. The college is, however, responsible if such students continue to cast discredit upon its own significance and its solemn high emprise. In the Century of a year ago, you may read: "We all slip too easily into the feeling that the presence of these [idle] students in the college community, while not beneficial, to be sure, is at least not positively harmful. A more fatal blunder could not be committed. . . The first and crying need of the American college to-day is the ejection, the ruthless ejection, of the man with the idle mind." 1 The author means, of course, the incorrigibly idle. At a certain age youth is naturally otiose. Our author, I suppose, has not this idea in view. He means the boys who are on the campus for social purpose, to pass the time; boys who have no intention to scholarship, who, did they live to the age of the patriarchs, would still be innocent, entirely innocent, of the slightest intellectual enthusiasm or endeavor.

Finally, to go back once more to botany, the culture of our most perfected plants must be maintained; it can

1"What is Wrong with the College," Professor Harold C. Goddard; Century, May, 1914. 
never cease. If we cease our effort, the plant reverts, goes back to the primitive crudeness of its wild state.

And so in the problems of the soul. Human culture for the individual concerns not youth alone; it goes on through early manhood, and is maintained in latest age, on ever-widening planes; and for the race it covers all the centuries! Even the scholar is but a beginner, as we know; just one at school; but he has made a beginning, since he has learned to love all knowledge, and every fine and noble thing; under continued favorable environment, he shall come at length to all the fairest display of cultured citizenship that his generation can afford.

For all these reasons these young people of the class of 1915 owe very much to Monmouth College - much more, indeed, than they now imagine. You shall meet your obligations only by beginning, at this good beginning, or commencement, hour, that life of cultivated manhood and womanhood which illustrates to the fullest the culture for which your college stands, and by a service to your country which shall be at once devoted, intelligent, and continuous as life itself.

The republic is in straits from day to day. To paraphrase the words of Mr. Lincoln, we are to determine whether a government founded as is ours, conducted as is ours, conditioned as is ours, confronted by unheard-of problems, social problems, industrial problems, political problems, international problems, "can long endure." The answer to that question is in large measure with the class of 1915, the country over, as with the class of '14 and '16 and all the rest. To men and women of culture 
must be committed all that makes for human weal, to-day and to-morrow and forever.

Elihu Root, a graduate of Hamilton College, perhaps the foremost lawyer and ablest statesman of the country now, recently, as we know, presided at a great constitutional convention, to rebuild the organic law of six million people of the Empire State. At one session an invited officiating clergyman did not arrive, and Mr. Root made the opening prayer himself:

"Almighty God, guide us in our deliberations. Make us humble, sincere, and devoted to the public service. Make us wise, considerate of the feelings, the opinions, and the rights of others. Make us effective and useful for the advancement of Thy cause, of peace and justice and liberty in the world."

Do not these, the event, the man, the language of petition - do not these illustrate in every highest way the service which culture, the culture which only the colleges afford in our democracy, must ever render to the state if the republic shall abide?

Young ladies and gentlemen, your speaker at this moment recalls a scene like this, when on a summer morning long ago two-score young men and maidens appeared upon a platform, like to this, to receive diplomas. Much that went on that morning he has forgotten; but the diploma, the parchment, writ in stately Latin phrase and bound with glistening ribbon bands, all delivered by the loving hands of our dearest friend and best well-wisher, 
President David Alexander Wallace,- this he remembers well!

Since that happy day in June six and forty years have passed. Time upon fair young faces that rise in memory from that far summer day has laid his gentle but transforming hand. All is memory now; the physical form and semblance long has passed. Each bowed that day was it in condescension? - as his name was called; for one moment above our young heads the hands of the great president were stretched out in final benediction; and then we strode away, each to a destiny all undreamed, unknown to mortal ken. Out into the dark we stepped on that June day, out into the darkness, each on his unknown way; but we knew it not. The sun was shining and the day was fair; but the way - how had we not been startled could we have foreseen that way!

Forty and six years have passed. Each has found his way, his destiny, in some part, now revealed. Already many sleep; the mission of life's busy day fulfilled, whether in the early morning, whether at mid-day, whether in the evening light, where some of us still linger amid the ungarnered harvest, watching where the slanting shadows lengthen. But from first to last, through all these years, not one of us has failed to cherish as his ideal, potent and precious, the pattern of manhood here revealed, while Wallace, Young, Hutchinson, Wilson, and Black ministered in full devotion of life's self-sacrifice before the flaming altar of eternal truth. Here and now permit me to lay before that altar the belated tribute of my sincere appreciation.

That high ministry has wholly passed to other hands. 
You younger people know only the tradition of honored names; but the ideals remain, clear, beautiful, glorious as of old. These shall not change. The decades shall come and go, another half-century shall speed its silent way, and one of you shall stand here perchance to tell for the class of 1915 the doing of life's little day. May it then be his to find in these same old ideals not only his own exceeding rich reward, but the promise of benediction to his country in culture that shall still survive to serve the state in centuries yet to be! 


\section{THE TEACHER AND THE STATE}

All lacking in recognition indeed your speaker might well be esteemed, did he not hasten in his earliest sentence to express appreciation of his privilege in this fortunate hour. To appear thus before some hundreds of enthusiastic young people, all expectant of honor and congratulation, might well stir the sympathy of any who would essay, by uttered speech, to meet the thoughts of his fellow-men. There is really nowhere in the free life of this commonwealth anything finer than the scene before us this morning; whether we contemplate the beauty of the immediate spectacle, whether we estimate the significance of this ceremony, or whether, more keenly analytic, we go behind the present and see in all this the culmination of varied effort, of days and weeks of toil.

This is the time for gratulation; weightier matters, I am advised, may now for this day, at least, be laid aside. Comenius and Pestalozzi, Herbart and Montessori, Hegel and Schleiermacher, and all the rest may be forgotten. To-day is to-day, and all its windows open to the future. Needless to say, that the future, for this class of 1914, is very bright. This is Iowa; white clouds only sweep slowly through azure deeps, flowers deck all the landscapes, and the sunlight lies upon the rising harvests. And yet, were we called upon to give reasons for such optimism as at this moment here prevails, such confidence, such security of mind, we might find ourselves, as 
usual, embarrassed for reply. We might begin to think again of examinations, happily now forever past; and only at the last might we fall back upon the general buoyancy of youth and find there, perhaps, the most obvious reason why, for us to-day, the fields and skies are fair.

This is commencement. But in one sense it is different from the thousand similar events which everywhere for school and college divide with the roses the glory of this lovely month of June. In the college world, generally, men come up to claim diplomas, position among educated people; here, not educated only are these young people, but educators; informed indeed, but ready to share their knowledge instantly on demand; the day, the hour, the ceremony significant of much. Here is a double relation; past and future, to be sure, but unusual in that past and future are thus in singular fashion joined. Men and women who have enjoyed the hospitality of the commonwealth now go forth in peculiar sense, to serve it.

Your speaker has no thought to be intrusive; he is merely an onlooker in this fascinating scene. But, if you please, he may attempt to answer for you the significance of the day by discussing briefly this double relation of the teacher and the state, receiving and giving.

Education is said to be a great, but very ordinary, means to a great, but very ordinary, end. It is all so ordinary that we forget sometimes the mystery that it holds. We are richer to-day; but what is our added wealth? We are happier; wherein our blessedness acquired? We are quicker and smarter; of what kind is 
our accumulated wisdom? What have we gained? What have we really received?

In the first place, none of us, I think, will look back over the years and attempt to find any complete answer to such questions in tasks actually or perfunctorily accomplished. There are always students who find satisfaction in the completion from day to day of lessons formally assigned. I am not sure that they are wholly to blame. I am reminded that teachers themselves sometimes seem to do the same thing. For admission to Harvard, for example, so many books, so many lines, so many problems are required. Lessons are assigned and lessons heard, not to say recited. Small wonder if sometimes we estimate our finished work by such a scale! It is like climbing stairs. We count the number of treads in our ascent, never heeding to what they lead, whether to new prospect or new vision, or to vision of any sort at all.

Now, of course this kind of work is all very necessary. To reach a summit, stairs are exceedingly convenient things. But in any case, how soon the stairway may be forgotten; especially if we are to live upon the heights. No doubt all work attempted in a school like this, has for its object mastery, in so far, of the subjects we attempt. If we expect to teach, of course we are expected also to remember, at least, the principal facts and data of our subjects. We can never expect to enjoy our rightful influence in our work, or really to count for the most in this world, unless we are recognized as authority in something, somewhere.

And yet, in all that we have done, we are, I hope, perfectly aware that our great gain is not in fact and datum, 
not in things that are recorded by any generous registrar, but in those things so hard to classify or name, recorded in some strange way in the book of experience, in the tapestry of each human life. You know by this time, I am sure, that it is not so much the subject, but the effect, that you have won. Latin, for instance, you have studied; but it is not in the amount of actual knowledge of great Caesar's speech that you rejoice to-day. Even now that hard-earned taste of ancient or medieval lore begins to die upon the palate, and promises soon to vanish quite, unless sedulously kept up, and to leave but a lingering reminiscence; and yet, - suppose that by some finest intellectual telepathy we could stretch a viewless wire back across the centuries as we stretch threads of copper across the valleys. Take up the receiver and let the Roman speak; you could hardly understand him. At this end of the line his Latin sounds Italian, French, Spanish, Roumanian, even. Nothing in it but has changed "into something rich and strange;" but you have added two thousand years to the compass of your life, and all the history of modern civilization lies between; this you have gained! You may not understand Caesar, but you do understand the outcome of Caesar's life.

German, too, you have attempted; and the most philosophic tongue now spoken among men has spread itself before you. You have caught some glimpses of it; but, perplexed by the genders, perhaps, of things inanimate, or overwhelmed by the genius that can keep in mind the unfinished first word of a sentence, going on, through phrase after phrase, only at length to find completion in 
some insignificant closing particle, and thus to attain in unbroken sphere a completely uttered thought, - overwhelmed by this, you have perhaps been content to carry hither only some lyric remnants, bits of haunting verse that immortalize Heine or Goethe; although perhaps even here the author is for you merely an unburied shade. But if you have studied your German rightly, as no doubt you have, at the mere word the torches flare again against the night of the old Teutobergerwald; the German knights ride along the Baltic sands; castles rise and are mirrored in the green waters of the sunny Rhine; the Hohenzollerns march to empire, as Frederick Second breaks the power of foolish France, gives Canada to English speech, and makes possible this commencement at Cedar Falls! That is what you have found in German!

Mathematics, physies have had their turn; and at this moment, most of your acquisitions lie in the fourth dimension of space. Pedagogy and even psychology boldest attempt to plat easy avenues to the conquest of man's soul - even these no longer stand out with that sharpness which their uttered principles did once suggest. Both perception and apperception have become, possibly, exception, if not deception; and yet-you know how to teach. Why? Because you have seen experienced, gifted teachers teach; and, more, you are confident, not of psychology, but of yourself; and success comes with the dawning of the day. You have studied natural science. Was it botany, geology, zoölogy? You may not now recall; but as you look out of the window this morning the world looks different indeed; trees and 
herbs are marshalled in a procession that extends into the past so far, that only some concept of life's beginning can ever again satisfy your dreaming vision. You have added to your own life the millions of years that lie behind us.

In fact, all along the lines of studied effort, if you are really normal students, I believe you are ready to admit that, while you have been studying all these things, you have not been limited by what you saw or heard, but your minds have far outrun the printed page, the speaker's tone, the measured hour or day or year, and you are away to claim an empire all your own, whose boundaries are the fields of time!

I am sure I shall not be here misunderstood. From what I have said, you realize that I am not belittling the idea or value of exact information. I beg you to consider that, as I said at the beginning, real efficiency anywhere is conditioned upon accuracy and breadth of knowledge. I am referring merely to the ordinary experience of the ordinary student leaving an ordinary college, or even a teachers' college. All exercises are but means. The value of the real outcome must be found in something else than mere numbered page, or treasured fact, however precious in itself. Only in yourself is the reward of a scholar's labor, only in experience shall such expenditure as his be justified.

You are not linguists, but you know what languagestudy means, how and why it is pursued. You are not mathematicians, but you appreciate the efforts of those who are. You are not men and women of letters, but you know in what direction lie the flowery fields of lit- 
erature, even if as yet you own not one! Dr. MeCosh, president of Princeton College, once when an old man read in chapel that famous thirteenth chapter of first Corinthians, which contains the phrase, "For we know in part" - . He stopped and turned upon his audience that scholarly face, lit up with wonderful light and crowned with the crown of age ; "For we know in part," he said. "But we know!" Now you have it! All these days, these years, we have been learning, and now at last we find as a result that we know, indeed; and - we know in part only. But the eyes of our understandings have been opened; whereas we were blind, now we see, we know! We have been learning; yea, verily: we have been learning to know!

But this matter of receptive education goes farther still, means more than anything I have so far suggested or described. Permit me to illustrate once more:

As You Like It is your favorite play, the sweetest, purest, most delightful piece of human fancy ever written. Touchstone, as you remember, is a clown, but wise and witty; only by profession, a fool. The shepherd is talking with Touchstone:

"How like you this shepherd's life, Master Touchstone?"

"In respect it is solitary . . . in the fields, it pleaseth me well. . Hast thou any philosophy in thee, Shepherd '"

Then the shepherd goes on:

"No more but that I know the more one sickens, the worse at ease he is; that the property of rain is to wet, and fire to burn; that good pasture makes fat sheep, and that a great cause of the night is lack of the sun." 
Now this is the outcome of the shepherd's experience; this is his attitude of mind, his philosophy. Professor James says, a man's philosophy is the most interesting thing about him. And here the shepherd, as each of us, has his philosophy, his sense of the world, his estimate of realities, of values; he has his way of looking at things; he is an optimist, a pessimist, or what not; he is discouraged or hopeful; and this is what we get from our contact with the things about us, with books, and teachers, and classes. From the atmosphere of this finebuilded hilltop on the prairie, from all our study, this alone we gain, this that abides. You came here to learn to be teachers, builders for the state, not to study arithmetic; you could do that anywhere; numbers may carry magic, as you begin to see, and transcend arithmetic; not grammar, only, but the grammar, the correct ordering of human life; you came for personal culture, for inspiration, for intellectual direction, for spiritual power, for a new vision of this world, for an attitude of mind: "Hast thou any philosophy in thee," teacher?

But not yet have I closed my briefest inventory of your winning, here beneath the elms, in these lovely associations; not yet. At least two more entries must be made to the credit side of your account. The first rises directly from the condition I have just described. It is an asset even more valuable than that attitude of mind which seems so all-important now. It is an acquisition that others, fortunately indeed, recognize better than we ever do ourselves; perhaps in ourselves we know it never; therefore I may tell it. I mean now that wondrous ability which God gives a man, of becoming better than he 
knows! The ability to serve his fellow-men unconsciously, and therefore more potently and more beautifully than ever will be told. These teachers of yours have that gift. You know it; they do not. You have felt it many a time and so share it; you shall feel it yet again. You may not describe it; you may not seek it; it is yours; it is the bloom of the fruit; it is the iridescence of the plume; it is the luminous brilliance of the wave; it is the blaze of the opal; the silent, unspoken, all-potent influence of each noble human soul!

It is said that Robert Moffatt, the pioneer Scotch teacher in South Africa, was impressed in early manhood with the idea that, could he only tell his story, all Africa would heed. In his old age, it is said that he thought of his life as a failure. But in both cases he was much mistaken. It is true that Africa did not wholly listen; but, on the other hand, it is also true that South Africa to-day is English, and in the line of all future social progress.

"In the glory of youth the young man sped Forth from his father's door;

'They will heed,' he cried, 'to the spoken word

For the great world rolls before.'

"In the weakness of age an old man crept Back to his father's door;

' $I$ have uttered my word and none has heard, And the great world rolls as before.' ,

No: don't believe it! Life is forever more than a spoken word!, Moffatt lives, and his work abides, though he realized never, as he thought, the expectation of his 
plans. Moffatt's son-in-law was David Livingston! and David Livingston was followed by Cecil Rhodes!

There is still one other asset which is yours this morning, and must never be overlooked nor forgotten in any such review as that we are making here and now. This last acquisition $I$ here mention is the wonderful circle of friendship into which you have been privileged to come, and in which hereafter you shall have abiding place. The united faculty and alumni of this college constitute a fraternity, a sodality, whose warmth and loyalty are of never-to-be-estimated importance and value to every man and to every woman privileged to enter the charmed circle. Here is no bond of wealth, of caste, of privilege, of religion, even; but nevertheless an allegiance that shall dominate all future years. You young people, on this fair June morning, have no slightest idea how strong are the bonds of such affection; and how hereafter with increasing years, in spite of yourselves, in spite of opposition, in spite of mishap, discouragement, and apparent failure even, the spirit and inspiration, the united courage of these associations, will work miracles and carry you out and forward to a life of rich accomplishment, of valiant service in this world.

Let us sum it all up: Scholarship, knowledge, learning - these you have in part; mental attitude, disposition, philosophy of the world, views of duty, character in short, felt but not seen of men - these you have in full; and then, behind all these, the organization and sympathy and mutual allegiance, the bond of common affection and purpose of this great college; such make 
for you this morning memorable forever, the commencement, the beginning of life beautiful forevermore.

But now, having thus sketched the outcome of past experience, let us turn for a little in the other direction, and see how we can use the gifts we have thus acquired.

This, at first blush, looks easy : we are teachers; all we have to do is to teach; and what is more, if we teach in public schools, as most of us expect to do, custom has prescribed what we shall teach : reading, arithmetic, grammar, history, geography, and such things. To this the Iowa statutes have sagely added physiology and music; and after 1915, agriculture, manual training, and domestic science seem to be "indicated," as the homeopathist might say.

This all looks simple enough; but if the argument just concluded has significance at all, it is plain that the province of a teacher in our public schools is just as much wider than any mere list of subjects, as his training here has transcended the mere exercises of the class room. I may not attempt to discuss all that the situation thus suggests. Three points only would I set in order, as this morning we look out on the open fields of a teacher's opportunity, - first, his work in the school room; second, his work for people outside the school room; and third, his work for himself.

In the first place, then, no service in the school room can be considered adequate which has not constant respect to the purpose which the commonwealth has in view in paying for the service rendered. The Republic looks out over the unbridled hosts of the democracy, mil- 
lions of men swept by all the strenuous fierceness of human greed, human ambition, human passions; she reads the fate of the republics of the past, and in justifiable alarm she summons her wise men; what shall I do? How shall I control a multitude so diverse, so fierce, so heedless, that I may live and not die? And the wise men give answer, "Teach the children; make men intelligent and righteous, and you shall live and not die." And the great Republic and each commonwealth answers - "Lo, here are my treasures; spend and spare not; do your utmost that my citizens may be intelligent and wise, and I shall never reckon the cost, that the Republic may live and not die." And the wise men go forth, and the school houses rise on every hill-top, and in every valley, on every plain, in every wood, from ocean to ocean; and the teachers enter in! Was there ever such a spectacle in the history of this world recorded in the book of time; a great people rising to educate themselves! Nobody counts the money, nobody mentions the cost; the laborer gives his penny, the millionaire his thousands, his millions; everybody votes "aye," that the Republic, the commonwealth, may live and not die! The school house stands with open door, and the teacher enters in!

And now the children begin to gather: you may see them marching, young men and maidens, little children, the boys and the girls; it is autumn; the cool air of morning freshens their youthful faces, and the tinted leaves are rustling about their willing feet.

The school room doors stand open wide and the hosts of the Republic enter in! The doors are shut, and the teacher stands in presence of her duty. She is set to 
teach reading and writing and arithmetic. Yes, yes! And then she begins to read, "that government of the people, by the people, for the people shall not perish from the earth!" Who wrote that? Was he rich? Did he have money and stocks and houses and farms? Did he have castles in Europe and dwellings in California? $\mathrm{Oh}$, no; he was poor; so poor that when a boy he could not go to school, but lay on the floor in the light of a fire-place in a prairie cabin, and wrought out his arithmetic on the smooth surface of a wooden shovel, polished in the winnowed grain at the threshing floor where by day he toiled. The children learn his name. They read the story of fifty years ago. They see old men moving about the streets, a copper badge their only decoration. Can they believe it that these were young once, as are they; that boys heard the voice of Abraham Lincoln; that thousands rose to his summons, heard no call to wealth; heard but the voice of duty; disappeared in Southern forests and along the swampy, sedgy rivers, and came back no more? These remain forever young, and the teacher reads again:

"Blow, trumpets, all your exultations blow!

For never shall their aureoled presence lack:

I see them muster in a gleaming row

With ever-youthful brows that nobler show;

We find in our dull road their shining track."

Who wrote that? Was he rich? Was he great? Did he have castles in Europe and palaces in New York? $\mathrm{Ah}$, no, he was poor; poor as men count wealth to-day, but rich, rich, as you see, in all nobler thoughts and ways. Even so the Republic shall be safe. That teacher is 
teaching reading; she is teaching literature. She has set up a new standard; and presently upon the minds of the young people there begins to dawn a sense of values that are real, that shine and ring through the years, and that can not be measured by all the silver coin of the realm, though silver were free as ever benevolent Mr. Bryan could wish it, and came in showers upon the pavement.

Such visions of value may not come in a day, though sometimes they do; sometimes the lesson of a day lasts for fifty years.

But if not in a day, yet during the years through which American children are moving forward to young manhood and womanhood, through the fair fields of our sweet, pure literature, through our more than romantic, heroic, and generally noble history, through the fascinations of physical science, you may lead them to such an estimate of things really abiding, and satisfying, and worth while in this world, that by and by you have a whole community around you devoted to ideals the best that men know; and by and by you have a generation of men loving cleanness and simplicity and beauty; wisdom shall be justified of her children, and the commonwealth shall live and not die!

On and after January 1, 1915, every one who teaches in our Iowa public schools must pass an examination in agriculture, manual training, and domestic science. But let us not err. Even here we seek not to develop intelligence in the ordinary conduct of our familiar agricultural operations alone; it is not only desired that a teacher be able to know a "hawk from a handsaw," a cart from a plow, a grain of barley from a grain of 
wheat, a cow from a cabbage; but we seek in fact something far different from this. We would develop in the minds of young people a love for rural scenes and things, gladness in the health and beauty of country life, the nobility and independence of its industries, contentment and joy in the most necessary, most ancient, and universal employment of the race. In other words, we seek again a philosophy, an attitude of mind for all our people, at once patriotic, satisfying, and sane in every way.

Such studies, therefore, shall not interfere with the ordinary cultural studies of our schools. I think I could show an intelligent boy in a few hours how to meet all the needs of a Jersey cow - and she is as finicky as the Duchess of Daisydown - but, all that the schools can teach, and all that the government can do, and all that life may bring forth, may one day still be inadequate, insufficient wholly, to meet the erying loneliness of that same boy's throbbing, longing heart!

Most of the educational criticism of to-day is the most superficial sort of pedantry. We are told that we must fit boys and girls for practical work, that the knowledge of to-day is worth all the lore of the past. In California, two years since, one of these fine critics demonstrated that high school students knew more of Roman history than of happenings reported in the journals of San Francisco, and immediately rushed out with the appeal, "Are our American schools set to make Roman citizens?" Had he turned his investigation the other way around, he had no doubt discovered that the loafers and worthless idlers of California cities know more of the 
prize-fights, police courts, and Barbary Coasts of San Francisco - the contents of San Francisco newspapers - than do the boys and girls of the high school, whose reading has been otherwise directed and to whom we are committing year by year the destinies of the republic.

All such criticism is based upon an extremely narrow view of what is practical. If that only is practical which makes for toil and for the necessities of daily living, if the needs of the boy and of the Jersey cow lie thus in the same direction; then our problems of education become simplified indeed. Men were once reckoned and called cattle; but it did not work. The French Revolution disposed forever of that idea. But any educational theory which fails to take account of humanity in man, which fails to reach human love and hope and aspiration, which fails to make dominant the best that mankind has thought and wrought, which fails to recognize the light that is brighter than the arc, the light that lit that useful flame, but shall burn long after every carbon point shall blacken in the glow of day - any criticism of any less scope than this is futile, worthless, meriting consideration only as benevolence might seek to save the critic himself. "I saw an angel standing in the sun!" says the man of the Revelations. The old Scotch preacher read it and exclaimed, "Ye can do little wi" that man wha has seen an angel stan'in' in the sun," and he knew whereof he spoke. The light of intelligence is brighter than the sun. We know all about that luminous sphere; and even discount his radiance, as compared with that of other stars, and boldly say at last that "one star differeth from another star in glory." 
And yet men say that only that education is practical which teaches a boy to compute interest, to manage a steam-engine or a linotype machine, to build a barn for the Jersey cow, or a palace for her owner.

The story is told of a young man and his wife, who stood on a tower in Florence. They looked on the valley of the Arno. They were Americans; possibly from Iowa. They saw never such a view: mountain and plain and river, and fertile field, garden and orchard, forest and city and palace:

"Here, snatching up a bit of coal,

A young creator flung a soul

Into a sketch upon the wall

Where still you see the vital scrawl:

It was four centuries ago,-

The boy's name, Michel Angelo.

Caiano, where for solace went

Lorenzo, the Magnificent;

Careggi, where he turned aside

From the Dominican, and died;

Arcetri, whence the unblinded eyes

Of Galileo swept the skies.

Of Vallombrosa, 'Etrurian shades

High over-arched,' whence Milton took

That image of the leaf-strown brook" -1

they even caught a glimpse. They saw all this. They had all that wealth could furnish; but they looked into each other's eyes and said, "How fine it would be if we only knew anything!" They knew many things, but

1 From a poem, La Capponcina, an Epistle to Friends, by Melville B. Anderson, privately printed, Christmas, 1912. 
they lacked that particular knowledge our California critic would despise; they lacked intelligence. It was not that they knew no Italian or Latin, or anything abstruse; but simply that they did not know the meaning of Florence; not even where to find the needed information; they did not know the meaning of their time, the history of the world. They had missed entirely intellectual satisfaction, intellectual joy. The only pleasure that wealth can not buy; only the teacher can bring us in sight of illumination such as this.

But in the second place your opportunity lies also outside the school room.

A former president of the University of Illinois, not long ago, as reported, gave to a graduating class this advice: "Keep step with the procession. It is a pretty good crowd, and it is generally moving in the right direction. Act with the party; yell for the ticket; and whoop it up for the flag!"

Dr. Draper was a very eminent man, commissioner of education for the state of New York. He no doubt was a thoroughly patriotic and useful man; but in this speech we can not agree with him at all. To take such an attitude is virtually to throw to the winds on the streets every ideal we set up in the school. Dr. Draper's intention was good. He meant that we should be in sympathy with the enthusiasm of our fellow-men, that we should be loyal to our own institutions as we find them, no doubt; and yet not for a moment can we agree with Dr. Draper's careless statement. He has the whole case turned wrong end to.

The business of the teacher is to be informed and to 
set the step for the crowd, and guide the direction of its movement. Even the flag may be carried in wrong directions. And as for the party, the safety of the constitution lies in the very fact that men are intelligent enough all the time not to act with party when the party plainly goes wrong. Mr. Bryan found that out, and so did Mr. Taft, and even our most illustrious leader of reform finds in Amazon forests betimes space for reflection. To the phrase, "Whoop it up," the distinguished body of purists now before me would doubtless immediately give answer, "Cut it out!"

But there are a thousand ways in which a teacher may serve his or her community and not enter the political field at all. We may even leave polities largely to men, as is still for a season the fashion, I believe, in benighted Iowa, and yet in social and economic ways find opportunity to serve the commonwealth to most noble purpose. Women avail to bring to a community the spirit of sanity, of cleanness, of beauty that touches every home, even the humblest, every avenue and street, even the widest and finest. Here is the especial field of the woman who is called to teach. She has the ideas and the inspiration; others will furnish the money, - for reason. Every civic problem, every effort for the welfare of children, as well as for the safety of their mothers, is field-work for the trained and gifted teacher, and makes everywhere for the conservation of our free institutions.

The difference between teachers is not so much in what they teach as in themselves, in their appreciation of what they attempt, their grasp of duty, their ability to serve. But, lastly, no man, as it seems to me, is sufficient for 
all these things, who does not somehow find perpetual recreation in some form of self-culture; and so in the third place I have ventured to suggest the teacher's duty to himself - the duty of continued intellectual effort in some field of intellectual delight.

Let us speak not now of organized graduate study; what I urge is broader than that, and will apply after all formal graduate work has been completed. I refer to the student's own care of his own intellectual life. No student passes through an institution such as this without finding somewhere his interest quickened, his taste aroused, so that he realizes his preference for some one definite thing - for language, science, mathematics, literature. Let him follow his preference. Let him by private study become the best arithmetician, the best astronomer, the best physicist in Iowa; let him pursue to the last detail the science of field and river, as everywhere such is now accessible; let him study his favorite language, his favorite page of history. In all these things rather in some one of them, he shall find the pathway of life. Perhaps literature he affects. How fair the field! How great the opportunity! How needed in Iowa the art! Study literature, read it, create it. On these rich fields its coming is delayed. But it yet shall rise from the spirit-peopled mists where our prairie rivers wind, from the golden shadows that move across our cornembroidered fields, from the haunting memory of red man and pioneer, as these move dimly now by forest, grove, and spring.

These are some of the things that shall save the teacher, 
and so make him mighty to save the community, the commonwealth.

In real physical things we are rich enough to-day. We have exploited the accumulated wealth of millenia and are surfeited. What we need is wisdom to use our inheritance. This we must have if we are not to sink in the mire of commercialism and see all high vision, all pure appreciation, blotted out for us and for our children. To avert such catastrophe, you men and women are this day set apart; to forfend it by your own loyal enthusiasm; by the ideals you set up to anticipate the swiftness of its coming, that the Republic may live and not die! 


\section{THE SUCCESS OF THE PUBLIC SCHOOLS}

I never have been much interested in failures. Indeed I incline to admit failure as a possibility in nothing except that which is intrinsically wrong. That of course is bound to fail sooner or later, and our interest can be but of a pathetic sort. When, therefore, I hear, as sometimes $\mathrm{I}$ do, men proclaiming the failure of the common schools, I am less alarmed. I am disturbed, of course, fearing mistaken judgment as to what is right. But my disturbance as the years go by is more and more slight; because, as I hope to show, as time passes I am more and more convinced of the success of our schools and that failure is far from them. And yet the cry is still abroad that the common schools are a failure!

In studying the situation with eare for many years, I find that those who make such statements belong to one or other of two classes. First, there are those who would attract attention to themselves by assailing something universally affirmed; as who should say that Sarah Bernhardt is a poor actress; or that a fine auto is not a handsome ornament to an American gentleman's dooryard; or that the Sahara is not much of a desert. These people have no special interest in the contention; they are talking for talk's sake, and may be dismissed forthwith from serious consideration.

But, on the other hand, there is a class of critics of entirely different sort; these merit our attention. These are 
men really interested in public education; sincere men, but, as it seems to me, men of more narrow vision; men who, though themselves not plumbers, yet deem the schools a failure, because every boy who leaves them is not trained with ready hand to wipe a joint; men who are not farmers, but think that young people should all study agriculture, etc. Or the critic is a philosopher, a man of letters, and deplores the lack of complete literary training for every human soul; he is a moralist or religionist or churchman, and says the schools are lacking in religious training; they are Godless. In short, these are generally real critics. Sometimes such a critic plainly has an ax to grind, but generally speaking he is sincere; he deems public education a failure because, as he thinks, some one thing is not realized as the case demands. He calls for changed régime, assuming that success or failure lies chiefly in the program, and if the results are in any way less fortunate we should blame the bill of fare. Such criticism may receive brief attention as we go on.

It will contribute to clearness if at the outset we consider just what is really proposed. Before we can discuss a particular machine as to its success or failure, we must know its purpose, what it is for; and in exactly the same way we attribute success or failure to any institution. The test of an invention is the accomplishment of an inventor's dream; the test of a patriot's vision, his prevision, is history!

What then do our common schools propose?

The common schools, as I conceive, propose primarily just one thing, viz., civic training. But this training shall be: 
First, universal; it must reach every one who shares in civic duty. In our system that means practically everybody.

Second, such training must be relevant, and, if possible, efficient; must create or help to create a citizenry capable of self-government.

My argument is that the public schools are a success if to a reasonable degree they meet these two requirements.

The first thing then proposed, as I esteem it, is equal educational opportunity for every child. It is believed that education is good; and if good for anybody, it is good for everybody. Accordingly, under this democratic, socialistic scheme, the school room door is open wide. Every effort is made, and is making increasingly, in all our communities and in every commonwealth. Expenditure in this direction constitutes in every city and township the principal item. The tax levy is high and seems ever growing, but if in a thoughtless moment the tax-payer utters a word of complaint, some one pronounces the magic word schools, and every complaint dies on the tongue; schools, schools, build the schools, plenty of them, give every boy and every girl a chance! Furnish not only teachers, but books and tools and shops, and even clothing. Make way for the children of the Republic; to-morrow shall be better than to-day!

Surely, as far as popular support is concerned, as far as public enthusiasm goes - and this without some basic reason soon expires - surely in the estimation of the common people, for whose special benefit the common schools exist, they are a success. 
But, secondly, as stated, as a further, let us say ultimate, purpose for which the public or common schools exist, I place citizenship, self-government, democracy. The crown prince is from his youth up carefully trained. $\mathrm{He}$ has before him always the very finest instructors, the highest intellectual and cultural models; and why? Simply that he may be fitted for the place he after while must fill. And so the youthful citizen of the Republic; we summon him to the more difficult task of joining all his fellows in the government of his country; to him and them we entrust the management of its vast concerns, the happiness of its millions; the direction of its pregnant future. What preparation shall we not have, what effort shall we not make, in view of such tremendous issues?

The king will govern better if he be hale and happy; physical well-being makes for mental sanity and wholeness; and so incidentally the training of the king shall concern, if possible, his own well-being and joy in life; and for the common school the happiness of the child, the citizen, in manhood as in age, becomes a consideration by no means foreign to its purpose. Indeed, if we go deeply into such a survey, the purpose of the common schools will presently become commensurate with our highest intelligence, and in theory, at least, find no limit this side the supreme accomplishments of the human soul.

The Greeks, who, as I read it, were the discoverers of civil and religious freedom in this world, six hundred years before Christ, established a system of public education for the purpose of developing individual citizens. 
Indeed, a free government can not conceivably exist under other conditions. Such government as the Greeks sought, as we seek, is more than a democracy; it may or may not be a republic; it is a sodality, a fraternity, a brotherhood of equals, each seeking the same thing for all; it is an enlightened socialism.

No one has more beautifully and exactly stated the purpose the schools have in view than the Puritan poet, John Milton. Milton was a republican, a democrat, if you will, and his remarkable, oft-quoted sentence, written nearly three hundred years ago, is for our present discussion the sum of political wisdom. "I call a complete and generous education that which fits a man to perform justly, skilfully, and magnanimously all the offices [duties] both public and private, of peace and war."

Stand off now and contemplate for a little the form of government under which we have elected to live. Divest yourself for the moment of all preconceived or inherited notions of what education ought to be or mean, and think only of the kind of training which a state such as ours shall undertake for itself in order to make the system work; and I believe that you will realize that John Milton's sentence is an extremely pertinent and noble utterance of a wise and noble man. Milton does not describe the educational ideals of the universities, of the church, nor even the education he had himself enjoyed; nothing of that sort. He was a scholar equal to any of his century; he was secretary of state for Oliver Cromwell and could write the dispatches of his office in the language of the court to which his message was sent; his learning in what we term letters was co- 
extensive with the best the world has treasured,- and yet, when he comes to discuss public education, he thinks not of any of these things. Instead he goes straight to the practical heart of the case and declares that public education shall fit a man for just one thing; for duty; for his civic duties; for all the offices (duties) both public and private, in peace and war. Noblesse oblige is the old French saying which means that very nobility puts the king under obligation; and Milton means to tell us that if we are to take the king's place, as in his time men did, we can do it only by assuming royal obligation; duty, duty, duty!

Milton would have a man look to it that he govern his own household, private duty, than which in a free government what can be more important; he would have a man join with his fellows to manage the block on which he lives, if citizen of a town; to see that each man has his own without suffering trespass; that the common alley is kept clean and sanitary, that trees are properly selected and properly planted; that walks are properly placed and properly built; he would have the citizen taught how to manage his ward, how to vote, how to elect the alderman; the mayor, and the duties of each; the management of the town, the city; that the duties are identical whether the town be large or small; that the government of farm and township are quite the same; and that to the management of commonwealth and republic we apply the same principles exactly until at length the whole country is managed by the simple discharge of individual duty, and the nation is governed by law. 
The success of the common schools, then, is seen in proportion as our people, now for half a century so largely trained in these public institutions, rise to the discharge of public and private duty in accordance with Milton's law, as we may now call it, doing their civic work with justice, skill, and greatness of spirit, unselfish generosity and love. I believe that it can be shown that Milton's law is not only ideal, but that in all our communities, wherever the common schools have a fair chance, its terms are realized to a remarkable degree in the universal public weal. Do not misunderstand me. No system of education, public or private, can usher in the millenium on this unhappy world. The natural antipathy, for one thing, between the differentiated races, will be a source of trouble, as it seems to me, for long, even though we should begin to-morrow to cease interference with each other. If it is true that "of one blood God hath made all nations of men for to dwell on all the face of the earth"; it is just as true, as the scripture quoted goes on to say, that He hath "determined the bounds of their habitation." When we shift the races and peoples about and commingle them, we interfere with the laws which have been long established and so render the problem of self-government everywhere more difficult.

Our civil war, which, in sporadic lynching outbreaks, still continues, is in this sense a racial conflict; and so also in a different way our Spanish and Mexican troubles. But in all this, even at this moment, a sense of justice and magnanimity, softly luminous but still brightening, may easily be traced in nearly all the slowly crystallizing policy of this Republic. Whatsoever of uniform phil- 
anthropic, brotherly sentiment obtains in our wider national life must be in some large measure attributable to the broad democracy of our public schools.

The people of this country are just now fortunate above all the nations of the earth. Men say it is because of our isolation. Doubtless in part this is true; although the old world also in some measure is isolated too. But there are inherent causes for our quiet, our happy, if less interesting, history. The open way to life, liberty and the pursuit of happiness has never been so broad in this world as it is in Iowa at this moment; nowhere is property so safe, religious liberty so secure; nowhere do so many people participate so largely in the pleasure of the mind because able to read, to write; nowhere is wealth so generally diffused and its enjoyment so rational; nowhere is government so real and yet so mild and so loyally sustained; nowhere is there less distinction of class and even of race; and this in the face of the fact that at this moment we are thronged with people of every sort and condition, not from the countries of Europe only, but from all lands, all sorts, Jews and proselytes, "Parthians and Medes, and Elamites, and the dwellers in Mesopotamia," all spreading and mingling in our population; and still we have peace, even in Chicago!

It is admitted that to meet such conditions the only possible transforming agency is the public school; if so, the success is simply marvelous.

But it will be said, the public schools are not the only factors contributing to our good fortune. This is certainly admitted. No child is educated by any kind of 
school alone. He is educated by his home, by the city, the neighborhood, the condition of the street, the social status in which he appears, the very climate, the atmosphere - in short, by external impulse that reaches and plays upon the pliant tendencies of his youthful soul, by his whole environment. A boy trained in our schools would find himself strangely handicapped if dropped suddenly into the Soudan, Persia, or even certain countries of Europe. The church helps, the city helps, the parks help, and the gardens, even the flowing waters of the streams; but after all it is the schools which, in myjudgment, lend that essential touch which makes the citizens who save the commonwealth.

But it is argued further that this can not be so, because the schools are failing so largely to reach our children, so many, it is said, are not in the schools; enrollment does not meet the statistics of population. It is said truthfully that many children are not enrolled, not subject to the very influences for which people so willingly and lavishly pay. For instance, in Iowa in 1914 the number of persons between five and twenty-one years was about 770,000; the enrollment was only about 500,000 . A system, no matter how enthusiastically proclaimed and supported, can scarcely, it is said, be esteemed successful when it really reaches only two-thirds of those for whom it is intended.

But let us not be too sure that we see the fact. It is trite that the age-limit we have selected is extreme. Thousands of children are not sent to school so early, and only the fewest of young people are in grades or even high schools as late as the age of twenty-one. Our 
records show that young people reach the University at the average age of eighteen and one-half years; and while the University is of course undoubtedly part and parcel of our system of common schools, nevertheless in its nature it must be always of immediate use to only a small fraction of our school population, and its enrollment at any particular time is negligible in our present examination. It is in general safe to say that enrollment ceases for a large number of our children near the age of eighteen.

To make my meaning perfectly clear, suppose we assume our school population today to be 770,000 , and admit that of this number 270,000 are not enrolled, this large shortage will be found to include:

1. Those attending private schools; perhaps 50,000 . Statistics.

2. Those between five and seven years, not yet entered, 10,000. Estimate.

3. Those between sixteen and twenty-one years, gainfully employed, 100,000 . Statistics.

4. Those between sixteen and twenty-one years, in the service of the home, in house or field, 100,000. Estimate.

5. Those really neglected, perhaps, 10,000. Estimate based on statistics.

Here the failure can be attributed to the schools only in that parents have not been so affected by them as not to conform in full to the more beneficent provisions of the law. The statute makes the age limits five to twenty-one; the judgment of parents runs from six or seven to sixteen or seventeen; and the difficulty is passed on from generation to generation. 
Perhaps compulsory laws will help; perhaps schools attractive to grown-up girls and boys will help; perhaps the recession of the so-called commercial spirit which today holds ever before our young people, as the only criterion of successful living, the mere ability to make money, - perhaps the disappearance of this idea presently will help; perhaps will help the education of parents, persuading them, both in season and out of season, that "of the lifetime one has to live for the world, a large portion - say from eighteen to twenty-four years, according to the individual's nature - is best spent in activities chosen for their value in making his whole life finer and more serviceable, irrespective of their immediate money price. The community that bravely insists on protecting the young against being used up in helping the community get a living, soon finds itself getting a better living, and other things of much more worth."

But perhaps, and far above all, we need just now a more continuous effort in our school administration. In my opinion the schools should never close. In the war for the salvation of the Republic, the war against worse than barbaric ignorance and sloth and greed, the doors of the school house, like the doors of the temple of Janus, shall never close, from month to month, from year to year, from century to century. There shall be no vacation, no peace, for there is no discharge in this war. The teachersoldiers may faint and grow weary, need respite and furlough, but in my judgment we shall never give our schools their maximum efficiency until we reach an almost perpetual session; no vacation for the physical plant; use it, use it, until everybody shall come in and 
find help and inspiration; if not in one way, then in another, and the enrollment shall match not the school population only, but if possible the census entire.

As it is, we lose so very much. We lose the summer almost wholly. We lose Saturday, and, I am sorry to say, Sunday in large measure. More than all, we lose morale, we lose control. In the long vacation we lose, at least in part, what we have gained during the labor of the rest of the year. When vacation comes we really change teachers; we really turn the children over to chance; we know not what we do; there is no superintendence, no supervision. Why should we crowd the curriculum during certain months of the year, at peril of both pupil and subject, and let all the summer go waste? Why shall vacation time not be given under supervision to the things the children like to do in the summer, to organized play, to the rearing of chicks and plants, to domestic science, to planting and sowing, to building kites, and wagons, and telephones, and boats, to all industrial employment, leaving if you will the usual school calendar less burdened for the proper presentation of subjects more specifically informational, to civic instruction, to the things of the mind, the things of the spirit?

As things go now, in a state where the life of the Republic depends upon absolute attention and perpetual vigilance, we voluntarily go off duty, go on leave, on furlough, one-third of the time. No wonder men talk of the failure of schools; unless we repent we may have the failure of the Republic to talk of before even we are aware.

But it is said that our schools are unsuecessful because 
of defective curriculum; no schools can be of any use which do not teach a great number of things, - botany, astronomy, physiology, Bible history, agriculture, Greek. It seems to one who ponders upon this matter almost providential that our schools have come so far without a curriculum definitely prescribed by statute. Our children are evidently taught basic things, whether they learn other things or not. To be able to exercise civic duty the boy must be able to read, to write, to compute accounts; with such knowledge, Washington, Jackson, Lincoln, and Cleveland accomplished all the demands of the republic. Nay, more: does not even such simple knowledge open the way to all highest things? With it Laplace found the way to the stars and discovered planets new; with it Faraday, the blacksmith's boy, prepared the way for all that has since been done in electrical science; with it Stephenson found the locomotive, Arkwright the spinning-jenny, Whitney the cotton-gin, Edison the electric light, Gray the telephone, Wright the aeroplane. Teach a man the magic of numbers and teach him to read, and you open the gateway to endless worlds!

Not that I would disapprove of all else in public school work; not that; but that I deem it fortunate that so much is left to the preference of the people themselves. Music and language, history, geography, civics, geometry, natural science, physics, - use all these things and other arts, as opportunity may open the way. Open for children the windows of the world wide as you may. Few or no studies are required; the choice is left to the people themselves. Now and then some meddler crowds upon the statute book some specific thing to be taught 
in the schools; vainly, I think. Seek ye first the basic things, and all other things shall be added unto you.

But after all the success of our American public schools, as discussed in the present paper, lies not in the curriculum, free or prescribed, not in the enrollment, not in our wealth and lavish expense; but in the personality and power of the American teacher. The American teacher is unlike any other in the world; for one thing, because in thousands and thousands of cases that officer is a woman. In our schools all the tact, all the wit, the enthusiasm and unquestioned patriotism of the American woman have been at the service of this nation, from the days of Horace Mann until now, and the result is what we are. A good teacher makes a good school; an efficient teacher makes a useful school; a patriotic teacher conserves the Republic. Her pupils learn to write, to read, to read that which is good; they learn order and method and procedure; they learn obedience, they learn to respect the rights each of the other; to love their country. The faithful Christian woman makes to-day the success of the American school. Without a text she teaches patriotism, without dogma she teaches faith; by her own high personal character she builds character and shapes the destinies of men. Her name may never be entered upon the world's broad scroll of fame; her fortune may be forgotten, and an ungrateful commonwealth may even refuse the pension which shall save her age from penury and toil; but the history of our common country will one day tell her triumph, and the glory of the future, the success of the common schools, shall be her own. 


\section{CULTURE AND WOMEN'S CLUBS}

Two thoughts occur to me as I appear before this distinguished company this afternoon. The one, of course, is that this is Lincoln's birthday. All famous things start to memory at the mention of his name, while we compare and contrast the seeming good fortune of this present hour, in appearance, at least, so prosperous, so beautiful, so free from conflict and from care, so different from all that Lincoln knew. The second turns on the fact that this is an organized congress of women, and we cannot but recall the social and political progress of women since the days of sixty-four and five.

To develop such thoughts as these might well be allsufficient for a Lincoln's birthday speech, and in fact such is the plan in what I shall go on to say. And yet, Lincoln's story has been often told; I must vary its setting if my hearers heed at all; and as for present prosperity, - well, even this, as will, I hope, appear, may hide problems pressing, dangerous even as those the great President toiled to solve. I shall talk of Lincoln and his time, not to repeat an oft-told story, but simply to find a background on which mayhap the meaning of present years and deeds may take more vivid color.

The really vital interest that everywhere attaches to the name and fame of Abraham Lincoln is surely marvelous. To the vast majority of those who this day name him, the great President, of course, is but a char- 
acter in history, like many another; nevertheless, the name of none other, that I know of, is greeted, whenever mentioned, with such general, nay, universal, heartiness, as if to tell of personal friendship and affection.

For some reason Lincoln is our own, especially in these prairie states. Our pioneer fathers knew him and he knew them. He had little formal education. $\mathrm{He}$ had no theories. The uncertainties of conflicting schools of human thought cast no wavering shadows for his unclouded mind. He saw with absolute clearness the simple facts of what proved a tremendous crisis in a nation's life, and he never got beyond those facts. The crisis and his life passed out together.

$\mathrm{He}$ was poor. For that reason, if for no other, the vast majority of men are on his side; he walked with poverty all his life and took the chief place in the great Republic of the world, having little, if any, property beyond his simple residence in an unpaved prairie town; and yet the memory of this man and the ideals for which he stood constitute, all unseen, a wealth greater than all our docks and cars, our buildings fine, because more vivifying and more enduring; in some way more beautiful and more to be desired.

I have nothing new to-day to add to the familiar annals of the sixties or of the decade just before; all we can likely ever know about our hero has long ago been said and written; the story is not only familiar; it is already old; but oun history is new, our destiny is just now in the making, and perhaps in this quiet hour, on this anniversary of Lincoln's birth, as our minds naturally return to the days in which he lived, to the peo- 
ple and conditions of his time, to the historic men and women who stood about him and to some of the things they did, memorable here and now, perhaps we may find something to interest, somewhat of inspiration, for problems just at hand.

It was my fortune, whether for good or ill, to pass the days of youth in the center of this great valley, and personal memory covers much of Lincoln's political career. The middle decades of the nineteenth century were great decades from every point of view, and the men and doings of that time are themes for fascinating story to this day. As I look back upon what I can recall, I appreciate, as I did not then, as perhaps did no one then, just how wonderful was the time, how remarkable were the people who lived and acted upon the open stage of our most eventful political and social life. It was an era of great men. We had the New England poets, we had Beecher and Sumner and Greeley and Lincoln and Douglas, and a host of men only less widely known; and while we reckoned these distinguished men, great men, yet, in no case, did we esteem them accurately, nor did we concern ourselves about their possible future fame. The men of our neighborhood thought it not worth while to hear Abraham Lincoln, although Lincoln and Douglas joined their great debate in a little city not very far away.

The reason for our less perfect appreciations lay, of course, partly in the oft-stated fact that no generation of men can forecast the ultimate judgments of history. That goes without saying. But the greater reason, as it now seems to me, was to be found in another, nearer 
fact, the presence of an all-overpowering social question which then engaged the attention of all sorts of men. Men of distinction and men of no distinction, all were alike concerned about the extension of slavery; and the question whether one man should earn bread which another should be allowed to eat, was a query having easy, straight appeal to every human soul. The simple greatness of many men, whose vision is now recognized, we overlooked, by virtue of the very hugeness of the problems with which they had to do.

If in those days we failed to recognize men, much less is it a matter of surprise, perhaps, that we failed altogether, or almost entirely, to note the moral and intellectual greatness of certain women. Their presence in public discussion was novel, even unwelcome; and when a woman did appear, her argument, her cause, her ability in presentation, all counted for naught in presence of a prevailing prejudice which made everywhere to her discomfiture. Women were as much interested in the suppression of slavery as anybody; and, as I could show you, if time allowed, they also, some of them, at this very time awoke to the realization of their own oppression; but only here and there was their voice effective in the universal hubbub of acrimonious political debate.

Yet there were some women who did make themselves heard, some who became famous. I may be pardoned, if in this presence, I mention one or two. Miss Susan B. Anthony, for instance, ridiculed as she has often been, was one of the ablest platform speakers I have ever heard. She had a fine presence; she had a clear, beauti- 
ful voice; she knew her subject and was absolutely so committed to it that she never faltered; she feared nothing. As one listened, he forgot the speaker; he noted first only the music of her speech, like a rain of silver coin upon a marble counter; then he caught the argument, the torrent of invective and sarcasm, the gentleness of appeal, and went away, if not convinced, at least conscious that he should have been. She was a great student, a fearless orator, and a great and noble woman. And she won! Prior to 1860 she secured, through legislation, for the women of New York State, the right to their own earnings and to the guardianship of their own children, amazing as that now sounds to us; and she won it practically alone. There was no women's club then in every village to help her; though she had doubtless the sympathy of thousands, she was victorious in her own might, because she felt that she was right; and she was!

Another woman of very different type, but similar history, was Lucretia Mott. She was seven years of age when the nineteenth century came in. As a girl she was a teacher in the public schools of New York, but presently became a preacher for the Society of Friends. In 1818 she visited old Virginia in the course of her religious work, and there saw black men and women and children doomed to bondage. She went home to New York, married, and forthwith joined her husband in a life-long campaign for the emancipation of the slave. She was a member of the American Anti-Slavery Society; but when, in 1840, she went with her husband to attend the world's anti-slavery convention in Lon- 
don and was excluded, with all other women who sought to attend, she suddenly realized that even white women were not quite as free from disability as might be desired; and the insult provoked an effort for her white sisters in the United States which, while not supplanting her interest in freedom for the slave, presently became dominant to the very latest day of her life.

On a rainy night, the ninth of April, 1870, your speaker witnessed in New York City the disbanding of the famous Anti-Slavery Society, to which, for nearly forty years, some of the bravest men and women the world has ever seen had devoted life and fortune. On the platform were assembled many of that brilliant band. Many made short addresses there; but bright in my mind looms not the giant Douglas with leonine shock of snowy hair, his voice of thunder; not Wendell Phillips, with his silver speech; not splendid Theodore Tilton, with his nervous enthusiasm; nor Julia Ward Howe, with her poem of jubilant exultation; but I see before $m e$, as if at this very hour, the petite figure of the tiny Quakeress whose courage had for forty years defied public sentiment, defied hostile mobs, now at the age of nearly eighty, standing in her place, clad in her Quaker drab, with a white kerchief about her neck, folded across her breast - I see the undaunted oratress, and I note her undiminished tone, voicing her great satisfaction that one chapter, at least, in the work of her life, one page in her country's history, and in the history of the world, was now complete. The book of record was finished; let it be closed and closed forever, since the possibility of human slavery had gone, and gone forever, out of the experience of human kind. 
Those Lincoln days were stirring days; they were preeminently days of action. Men and women met the great problems of their time, fought them out, and, as they could, thought them out - the women battling generally unaided and alone. Things were done! Many were the res gestoe, the things attempted, but many also the res versatce, the things pondered.

The Lincoln time was a time of action, because a time of war, and it was just in those years of action that the women of this country began to find themselves. The great commissions, aiding the civil government in the care of the soldiers in the field, gave women in those times their opportunity. They were organized and worked together, with but one end in view, in every village, more potently in every city, most of all in New York and Philadelphia; but over the whole country, women learned to do things in an organized way; they found their power. It is to be remembered that on this side 1865 begins the story of every great women's college and of every women's club in the United States.

However, at the end of the war, with the passing of necessity, the lesson learned bade fair to be forgotten. It remained for a curious incident in connection with the coming of Charles Dickens to this country in 1868, to re-awaken women to their real social and political status, to bring about an organization that became permanent; and did, as a matter of fact, make possible the assembly of this hour.

The New York Press Club, in March, 1868, gave a dinner to Dickens and refused admission to women, many of whom were at that time engaged in newspaper work in the city. "We'll have a club of our own," they 
cried, and under leadership of Mrs. Croly (Jennie June), an Englishwoman, they organized Sorosis, the first women's club, the first women's organization in which the interests of women, and women only, held the place of first consideration; the first women's club in two thousand years; for be it remembered there were clubs for women in the days of Aspasia, and of the Caesars, in what we term pagan Greece and un-Christian Rome; but none, until Sorosis, in all the centuries named of the Christian church.

The new social organization was by no means welcomed. There was at the time, of course, no lack of jest and petty wit; the members of Sorosis were, for instance, called "sorry sisters", etc.; but there was real criticism too in plenty. There was, it was said, no place for such a thing as a women's club; such had no aim or excuse for existence, women knowing nothing of parliamentary law, could not govern themselves, or accomplish anything worth while even if they wanted to.

Curiously enough too, the organizers were ridiculed, and the organization decried, because men were not made eligible to membership! Only think of it! In Boston about this same time Mrs. Severance was organizing her woman's league, to which, in the generosity of her good heart, men were admitted, poor dears! and on learning of this, some of the charter members of Sorosis actually withdrew; Kate Field among them. So difficult was it for the finest of New York women to come out from the traditions of centuries and stand alone, to defend themselves and the ideals God had entrusted so largely to their hands! 
Let us study Sorosis a little: it shall be worth our while.

In the original constitution of Sorosis, provision was made for two meetings a month, one to be largely social; the other, for members only, should discuss the advancement and independence of women.

Ten committees were set to report to the formal sessions of Sorosis: committees on art, the drama, education, house and home, journalism, literature, music, philanthropy, science, and working-women.

As we study it now, while the broad range of the program may surprise, I believe its scope and comprehensiveness will seem almost prophetic; certain it has been a warrant and stimulus everywhere to most useful, cultural, and civic endeavor. But at the outset it was widely criticised; first, because TOо BOLD, too ambitious; and second, to be sure, because TOo TIMID, too little aggressive!

I have no doubt the charter-members of Sorosis were oppressed by a sense of timidity. What attitude could have been more natural? They were doubtless surprised at their own action. The idea of resenting the slight put upon women by the New York Press Club was itself startling in its boldness; how much more the proposal to crystallize that resentment in terms of enduring protest, by the organization of an independent social effort in which men should forever have no part. But, on the other hand, women who had come through the experiences of the Lincoln days were sure that the Sorosis program was feeble to a degree. Mrs. Stanton, who for twenty years had been working for a national suffrage 
association, no doubt felt disappointed at lack of even mention of what was, at that time, called "woman's rights"; but her day was not yet. As a matter of fact, the organizers of Sorosis were ladies of literature. One could not expect much militarism from people who used such pen-names as Grace Greenwood, Jennie June, or Fannie Fern. Perhaps had George Sand, or George Eliot, or George Craddock been citizens then, the comittees had been named more to the taste of Mrs. Livermore and Mrs. Stanton; but the issue, as we see it now unfolded, had never been so fine, nor had women been confronted, as now, with the opportunity for public service, which is increasingly their own. Some women expected an organization to do things, but the field of battle gave place almost entirely to the charm of study and the pursuits of peace.

Nevertheless, the idea of doing something practical in the commonly accepted sense of the word was not omitted, and has been more or less prominent in the purpose of many a similar organization throughout the country since. Every club worthy of the name starts with the idea of some special service, but often passes on to ambitions of a different sort. Sorosis attempted to ameliorate the condition of the working women in New York City, and in so doing touched, as it seems to me, after all, the greatest of our national, shall I say human, problems, both of that time and at this moment, the question of poverty, the question of sufficient wage, the question of human homes, the question of the children. This question, as we shall presently see, faces us now in tremendous fashion, and its issues draw on apace; its solution, however, seems far off as ever. 
However, in giving principal attention to art and literature, to things of beauty and refinement, Sorosis was criticised as lacking interest in things of present value, was dubbed dilettantish; in short, impractical.

The same charge is brought against women's clubs to-day, as against many another institution founded for purposes largely ideal or esthetic. It is said that schools and colleges and universities fail to keep up with the times; remain less practical.

The word practical has a Greek origin and is indeed a vigorous word. It refers to things that ought to be done, that have value when done, or in their doing. Practical things are do-able, directly serviceable; and practical, so far, stands for activity, for visible action.

Practical things are good. A moment's reflection suffices to show that such are, in our human experience, basic. We must act, we must do something, or we perish. The animals act; actions proceed by instinct even; at least we shall all agree that action without knowledge is a matter of experience all too frequent. Action is easy; everybody goes in for doing something; we are nothing these days if not practical. We glory in our wireless telegraphs and telephones as practical triumphs; our auto-cars have transformed not only locomotion but our whole social fabric. People who before had never thought of leaving home now traverse the continent.

This is Lincoln's birthday, and, careless in the midst of splendor, we contrast the peril that was his; admire, perhaps, his noble spirit, and then congratulate ourselves that we are free from tasks like his. But surely we are mistaken. All this splendor of modern life, all this 
achievement of industry, setting men free, from the old shackles of time and space, all this invention, this machinery to exploit the world and make us rich - all this carries with it, as it seems to me, elements of peril, peril even by the very fascination of its novelty and excitement, making us forgetful of all that humanity has learned to prize.

It may seem reactionary to call our industrial triumphs hazardous. But are they not so, even in literal sense? Aeroplanes and zeppelins in struggle for the mastery may yet destroy the Louvre and the Vatican.

Our real and immediate danger, as it seems to me, takes two phases: the first affects our young people, and so the immediate future; the second affects our whole population, both present and future, because it shows the oppression and discontent of the sons of toil.

Our triumphs have made us rich; our young people, great numbers of them, are set free from the necessity of initiative and labor, and instead are constantly met by every sort of nervous excitation. The dance seems absolutely irresistible. Many young folk, all unemployed in serious tasks, tango the night away and spend insipid hours at cards, as if to "bridge" over the sad vacuity from one idle amusement to the next; sacrifice of human life, wasteful as war. Who can contemplate the fact and not fear for the Republic, in peril to-day even as in 1861. We have for our children glorified the socalled practical, until they begin to measure all human success in terms of luxury, of physical comfort of wealth,- - after all impossible to thousands, - and have forgotten that life itself should be reckoned practical, 
that a successful republic is an intellectual achievement; and that in the great game, even though a leading part may be denied us, yet are we, every one of us, playing for our very LIVEs!

Now over against this first peril, born, as I think, of misconception of real values, of overestimate of industrialism as a universal, all-sufficient social basis, we may set as one corrective at least, the practicality of culture, the pursuit of genuine culture, the joys of intellectual life, the program of Sorosis, the dream, the effort, of a thousand women's clubs. This will surely help somewhat; it is for us now to answer, how?

There are wide fields of knowledge which lead not to action at all, but which fascinate nevertheless; afford us pleasure; which need only presentation to be loved; which lead to peace, to joy, to the unseen sweets of life; to judgment, to reason; to values accumulating in the hidden chambers of the soul, even as the wealth of Minnesota harvests gathers beneath the silent summer sun in the fields of ripening grain.

Shall I illustrate? I am very bold; I go to antiquity and take the remotest illustration I can find. I have here in my hand a small tablet of clay. As we look at it, we see that it bears some strange engravure. On this side and on that are delicate etchings, curious lines, uniform yet curiously arranged. Evidently a legend, something to be read. By dint of much study, by long comparison, at length the student makes the message plain. Here is a deed to real estate, a conveyance, if you please.

It tells how a farmer once conveyed to another a bit of the Acadian plain, with running water, water for ir- 
rigation; and the picture rises! Men were living then! There was a city and from it stretched, far as sight could reach, orchards with the green of silken fields. By these were walks and highways and purling waters, where the fountains of Tigris came down to make the desert bloom. You might hear the voices of men, the songs of women, and the shouts and laughter of happy children; but this was sixty centuries ago! Through such lapse of years only the stoutest imagination avails to find its way. Yet here it is; the record not to be disputed. Here are the voices of our fellows sounding from that far time, and the spell of our common humanity is upon us with a charm we may not resist. Since that day, nearly two hundred generations, as men reckon, have risen perchance and disappeared, and here at last are we, breathing the vital air, watching in our turn the glistening fields of summer, even as did they of Babylon's forgotten plains. Not practical, this bit of clay? No, not practical; we cannot eat it; we cannot burn it; we cannot even sell it. But we can UsE it; we are using it; it is fascinating; we enjoy it!, and what more practical than that which gives us joy? We have opened in an unexpected place a window, a new intellectual horizon, and the view is interesting, vast, wonderful, and abiding. We knew that behind us were a thousand marching generations, and lo! we see them on the way, and their dim figures live and move and speak again. A good orientalist before this assembly would give us a year's food for thought and a vision to last us the rest of our lives! Is that practical?

People who are concerned alone with things of im- 
mediate physical use, who call for financial or as they say practical return for every effort, may open their eyes, widen their vision, reflect just a little, if that be possible; and realize, once for all, that even our modern science, which has so transformed the world, is, to your self-named "practical" man, in its very nature, essence, and life, as impractical as poetry. Why, even science dreams! Science has visions; science sets out to make visions come true; for what? For ITS OWN HIGH SAKE! For invention? No! For money? No; for knowledge! Do you suppose Franklin tried to invent lightning rods, or Faraday dynamos or wireless stations? Not for a moment! These men were studying electricity and physies, appealing to intelligent people; pitied, no doubt, by the smúg practical man of the time. Science finds the truth; invention puts it to use; but without science, no invention; without poor, obscure, toiling science, no gasoline; without gasoline, no engine; without engine, no Ford!

Science is star-eyed; she treads her own high way of investigation and research, knowledge her ambition, and truth her high reward; telephones, electric lights, control of human ills - these but the incidents of her progress, the by-products of her patient, ceaseless toil. Science counts them not.

Take another illustration. Who is the most distinguished woman on earth to-day? Madame Curie. Who is Madame Curie? Professor of physics and laboratory director at the Sorbonne, lecturer to the school for girls at Sèvres, the town whence you buy your finest china. In 1903 Madame Curie shared with her husband, only less 
distinguished, the Nobel Prize for that year, as recognition of her researches in physics: in 1911 she alone received the Nobel Prize for chemistry, $\$ 40,000$.

What had she been doing? Was she seeking something practical, in the sense of the street? Did she strive to discover some article which, when found, the world entire should use and accordingly must buy? Did she seek to exploit the resources of her country, securing control of natural wealth, and so enabling herself and friends to fix for years the price of some essential commodity? Not at all; not one of these things did she dream of: She discovered polonium and radium, two most obscure, unheard-of metals, extracted with almost infinite pains, labor, and skill, in minute amounts from pitchblende, a mineral found in mountainous countries and of probably volcanic origin. Of radium, the more famous of these metals, there is perhaps scarcely an ounce to be seen, taken all together, in all the laboratories of the world; so difficult is it to secure. Yet radium in its peculiar properties is a substance fascinating beyond compare. Why? Because it modifies all our previous theories as to the constitution of the physical world. Radium gives off a certain peculiar radiation; mysterious particles emanate as if from sources inexhaustible. Go down to the physics laboratory at the University and see the radium clock. I have seen an audience of thousands watching in breathless interest the rise and fall of those golden petals; pulsating whether we watch or not, pulsating for days and years it may be, or for centuries together, as if to realize at last the dream of perpetual motion! 
Such is Madame Curie's poem; such is her gift to the world, changing our vision of the universe, filling it more richly with a new splendor and unapproachable beauty. Is this practical?

I have said that Minnesota women would be charmed could an orientalist tell them the story of our human past: how shall they not delight to hear a man of science tell them of a woman whose researches are timeless, interpreting, as they do, past and present and future, and glorifying for our finite minds, not the world, indeed, but the very universe Over against the practicality that is evidently threatening our social life I set with confidence the practicality of intellectual life and interest, averring that while this will not do everything, it should help.

Another human interest which must, more and more, be set against the material, almost purposeless trend and tendency of present life and manner, relates to beauty, the beauty of art and its manifold expression. Our instinct for beauty is as old as that for action, and likely to be equally enduring. I have sometimes heard lecturers express their wonder that astronomy should be the most ancient science; that men of the early recorded centuries should have ignored the study of man, the study of animals, of rocks, of the very soil beneath their feet, and have given attention to the far-off stars. We do study the soil, but we have come to it last of all. The reason, I think, is plain. The heavens are BEAUTFFuL! Primitive man was overwhelmed by the splendor of the slowly moving spectacle. The majestic progress of the sun, from the gorgeous chambers of the east to his 
glorious going down, and the moon walking in brightness, - these wonderful heavenly objects have never failed to elicit the liveliest interest of humanity. Men who must needs in those days watch their flocks by night, did in the long, star-lit silence, discover the secrets of the skies.

But why? Because, as I verily believe, beauty belongs to every fraction of this universe, and has its eternal place in us, as another basal instinct, masterful as that for action. If, as is maintained, men and women of science are not impelled by hope of reward, but only by love of truth, I believe it is also true that they are wonderfully swept on by a love of that omnipresent beauty confronting them in every field, in earth and sky and air. Professor Tyndall, in his famous Belfast address, brings this out in argument, perhaps unintended, and therefore yet more potent. Perhaps it shall one day turn out as Keats has told us that beauty is truth, truth beauty.

Now, all our art, all our effort at beauty, every attempt of our hands to make beauty for ourselves, to express as best we may the passion that stirs our souls, whether by color, by crownéd pillar, by music, by drama, or by poetic form of speech, every such effort of human genius may and does become a most potent factor in the life of everybody's every day. These also shall help us, I believe, to save ourselves and our children in this time of transition, of nervous passion, instability, unrest that surely, at this moment, puts in peril the Republic that Lincoln gave his life to save.

In a new book which I have recently enjoyed, the au- 
thor, Hon. Arthur J. Balfour, former Prime Minister of England, tells us how the fine cycle of our human interest includes three things: action, knowledge, admiration; we act, we know, we admire. This seems to me not only an elegant summary, but it presents perspective, and gives the due historic order. This is in fact the order in which the present argument has to-day come forward. Action, the practical in the narrow sense, - this is the all too dominant spirit of this time; knowledge, - this is the dream of the student, of Madame Curie, of Langley, of every toiler who made possible Edison, and Graham Bell, and Wright; and finally, admiration, - this is the foundation of art and of all the joy that springs from the appreciation and apprehension of beauty. To complete realization of right human living we need each and every one of these three phases. You may begin with either; action may lead to knowledge and knowledge to admiration; or admiration may lead to either of the other two, though less likely. But the point I bring is that all three are human, all three make up the fullness of normal human happy, civilized, enlightened living.

So much for our first danger and some of the possible antidotes: now let us see about the second. Here are certain facts.- Notwithstanding all our progress, notwithstanding all our electric lights and electric cars. our roads and cities, our schools and laws, it still remains true that a vast segment of our population consists, and will probably long consist, of wage-earners. By wage-earners I mean men who are laboring from day to day in industries whose continuance they cannot, do 
not, control. Of these in the United States in 1910 there were more than thirty-eight millions!

The researches of students indicate that in favorable years, year in and year out, one-fourth of this number, in round numbers ten million wage-earners in our country have not sufficient wage to meet, not the requirement of the three phases of human interest just cited as constituting normal human living - not that, oh, no!, not that, but not enough for the basic FIRST, not enough for action, not enough for necessaries of actual physical life, - shelter, clothing, and food. This takes no account of the incompetent poor who are and always must be cared for, because for one reason or another, fault of body, or fault of mind, incapable of self-support; such are not here mentioned. Our concern is with the normal laborer only, the man or woman who could and would properly maintain himself or herself and those in dependence, if wages were constant and sufficient.

In other words, in the richest country in the world, in the country of which we are so proud, where industry and invention so rejoice and triumph, in this country, there are millions of wage-earners whose income in any single case is insufficient that a man shall have at any one time sufficient food, sufficient clothing, and suitable or adequate shelter for himself, his wife and two or three children; this says nothing of insurance, or of accidents, or old age. Does any one suppose that in presence of the constant display of superfluous wealth, made by large numbers of our people, in presence of the wide-spread idleness of thousands who do no useful service, simply because labor is not necessary to their daily 
bread, - does any one imagine that in face of such conditions this very large portion of our population can remain very long content?

Abraham Lincoln did indeed in 1863 free three million slaves; but the black men were at least clothed and fed and housed, and kept in health; other conditions had made them useless, unprofitable. Our underpaid are both black and white, possibly in about equal numbers. Lincoln hardly imagined that fifty years after his master stroke we should contemplate the spectacle of ten or even five millions of our fellows, so underpaid, as to be under-fed, insufficiently clad, and badly housed. Can we placidly contemplate such a spectacle as this, the country full of riches, and still imagine there is no danger? Believe it not!

Thousands of these toilers are women, girls who live in cities, clerks in great stores, toilers in great factories, drudges in great hotels and business palaces, even teachers in schools, I am told, who have only meagerest wages, hardly sufficient to keep soul and body together; not enough for action, to say nothing of the other factors in normal life, as suggested by Mr. Balfour. Think of a woman deprived not only of all opportunity of meeting her desire for knowledge, but deprived of all means of gratifying her innate passion for beauty and starving from day to day beside! Is there no peril to the Republic in these things, no problems here like those which Abraham Lincoln gave his life to solve?

But, you say, we do not like this: it begins to grow serious; it is too grave for our societies of women. I hope not. In Iowa, the other day, I heard President 
Wilson talking to thousands of people, men, women, and children. In his address there was a tone of evident alarm of dangers from without. The President shall be our watchman there. But to-day we are confronted by perils at home in which men and women and children are concerned; and in these the organized associations of women can, I think, accomplish much.

The first problem cited a little while ago concerns the right training and employment of our children. It is trite that women are confessedly specialists in this field. The direct individual influence is here so great that we are apt to esteem association, organization, unnecessary, or at least of small importance. Furthermore, women are by nature conservative and very keen discerners of moral and esthetic values. They realize that an electric light, beautiful as it is, owes its whole value to the circumstance that it enables us to SEE: vision is better than electric light! The touring-car is valuable only as it enables us to journey in the open air; but its value fades immensely if we kNow nothing of where we are going or what we shall see or where we shall arrive. For all these reasons the problem stated lies with women.

In the latest biography of Lincoln, a conversation is cited in which Lincoln tells what his mother did for him. Did she show him the kingdoms of this earth and their tinsel glory? Oh, no; she was poor and lived amid the cabin-housed pioneers of the prairie, and died before the lad was ten years old; no; she read to him the ancient stories of the Bible, stories whose style came out later in the Gettysburg address and the second inaugural, to the astonishment of the world, classics in the literature of the race! 
The individual influence of woman is great; but in organization, by their skill in shaping local sentiment, forming public opinion, and so purifying public taste, they combine individual influence, and really create an atmosphere in which culture and refinement have naturally their place, and fine appreciation. Instinctively, I think, the women's clubs turn the attention of themselves and others to things pure and beautiful. They affect letters and music and art. They are housekeepers, and they go in for municipal housekeeping, for clean streets and lawns, for parks and trees and flowers: they study moral conditions, and seek the social purity of ward and street, and, in my judgment, these things are immensely practical; they shape the environment in which our young men and women grow to life's estate.

It is to this same end that, of late, we have urged vocational studies in public schools, in schools specially endowed as at Gary. These things are fine; they will help. Only do not imagine they solve the problem. We may not discuss the matter here. It is well to train a boy to be a blacksmith or a farmer, but he must also in the Republic be trained to live: it is well to train a man to be an operator in a mill, but he must also be trained to care for his wife and children and make them rationally happy.

This brings us now, once more, in sight of our second problem, the problem of the man who labors with his hands, especially of that fourth man; every fourth man, remember, who does not have wage enough to live. All your women's clubs, all your literature and poetry, all your beautiful things, amount to nothing to him nay, are simple mockery, so long as he does not have 
enough from his earnings to see himself and family properly fed and clothed and sheltered, all at the same time! What can women's clubs do with a case like this? Two things: first, find out the facts in specific cases; and second, report the facts; study them and aid, if possible, scholars and employers alike, who are striving in school and factory, in office and in mine, in legislative halls, to bring about a happier condition.

It is said that the minimum annual wage on which a sober laboring man may live decently at this moment and care for an economic wife and three children, sending these to school, is eight hundred and twenty-five dollars. One-fourth of the laborers in this country fall below this minimum. The situation makes one sick at heart. The women of Minnesota can do so much, have done so much, will they not, as opportunity offers, help also in this particular field until in every community, to the largest extent possible, every man of toil can stand erect, proud of his own self-respect, his children able to share on equal terms with those of his employer in all the privileges of the public schools, and the opportunities to which these open the gates on every side? The conditions are right; they will at last, they must at length, prevail. Only so shall the Republic, the Commonwealth, be safe.

I have spoken of legislative action; nine States of the Union have now minimum wage laws. Minnesota is on the list. Every women's club in Minnesota should have a copy of this law and know the situation.

And so, in conclusion, I come back to the original programme of Sorosis. I think I have shown you that it is 
practical in the higest sense; from start to finish; from the first item, which calls for the study of art, to the last, which asks after the conditions of working-women; it suits the conditions of to-day with an exactitude that led me at the outset to use the word prophetic. The activity among us that is practical because profitable will take care of itself; but these other interests that are practical because serviceable to humanity - for these I would enlist the sympathy of the women's clubs of Minnesota and of all our western States.

Our problems generally originate in older communities; they originate in the East; and the East shall no doubt help in our investigation. But, as in Abraham Lincoln's day, the final solution, the happy solution, may yet be furnished by our energetic, optimistic, more youthful and sympathetic West.

"Men look to the East for the dawning things, for the light of a rising Sun,

But they look to the West, the crimson West, for the things that are done, are done!

The Eastward sun is a new-made hope, from the dark of the night distilled;

But the Westward sun is a sunset sun, is the sun of a hope fulfilled." 


\section{THE GIFTS OF SCIENCE}

Dull indeed must he be to all that makes for strength and beauty of architectural proportion, elegance of material and grace of structure, who fails gladly to appreciate and rightly to prize the beautiful building we celebrate on this happy summer day. These massive walls, these pleasant aisles, beautifully lighted and well appointed laboratories, must excite the admiration of every man who loves the builder's art, especially when that art is consecrated to the service of high intellectual endeavor. On the fortunes of this hour, I am, therefore, well permitted to congratulate the people of South Dakota, the regents, the faculty, and the students of this University, and all friends of education and science everywhere, and to voice the earnest hope that the meaning and purpose of the effort here culminating in completed physical appliance may not only not be missed by any one here present, but may in very fact be an inspiration and impulse for days and years to come.

Were a stranger to our civilization and the present state of human learning to visit us this afternoon and be suddenly introduced to the scene before us, his wonder we may well imagine. Show him these elaborate halls, these beautiful rooms, and all this mechanical equipment; tell him the cost of this building; tell him its purpose - for nothing else than to further research among plants and animals; to discover the constitution 
of the surface of the earth and to spread the knowledge of these things among men - tell him so much, and such a visitor would certainly experience great surprise. Tell him that here is something new : that study here is all apart from literature, from the philosophies and humanities, and his surprise will heighten still the more.

Tell him that this is only a single instance: that in every State, in a hundred cities, the same thing is doing, has been done: and his surprise will be deepened into wonder as he learns that the people of this country and of the world yearly are spending millions of dollars at the behest of what men call science, in a demand never satisfied, ever increasing; insatiate as time, unsatisfied as human ambition itself.

If our visitor be an intelligent man, as he must be to appreciate all that we show him, his sense of astonishment will forthwith provoke the inquiry: "What means such vast expenditure? What is your expectancy in such investment? And what returns are they, which those who thus spend their treasure have received or hope to receive to justify an outlay so lavish, persistent, and yet seemingly for ends so far remote from humanity and its purposes, its enjoyments, hopes and fears?" $\mathrm{He}$ will say: "Here is no vast library, stored with the learning of the ages; here are no panoramic halls in which the art of busy centuries may charm the appreciative soul. Here is only an appliance for the study of the lower creation, even the lowest; apparatus for the investigation of plants and these the most insignificant; what profits, then, such study and what advantage has science that it should receive consideration so universal, 
patronage so munificent and endowment so unlimited from the treasury of the State? Surely your science is immensely indebted, but what has she to show on the credit side? What has science done? What is she doing in the world?

Now these questions are well put: they are real, and their consideration may be well worth our attentive examination, even though the questioner, as here related, be hypothetical and imaginary. Nay, the questioner has his place among us; there are men quite conversant with modern life, who even yet are inclined to state the problem in the query of old: "To what purpose is this waste?"

In the brief space assigned me on the present programme, I may not hope to answer such questions in their fullest scope. The answer is vast, far-reaching as our present human experience, and touches in one way or another the whole compass of modern living. In fact, the answer is two-fold:

In part, open and read of all men; in part now only dimly seen, to be reckoned up only by some future student who shall prove capable of weighing and rightly estimating the great impulses in the intellectual progress of mankind. The return for our investment is, therefore, two-fold, just as there are two ways in which any obligation may be met - the debt may be paid in kind, or it may be resolved in service rendered.

In the first place, then, science pays back her cost in kind; dollar for dollar, a thousand-fold. Let us look at one or two examples.

The chemist taught Henry Bessemer of England the 
constitution of English iron ore, and the difference between iron and steel. Bessemer accepted the conclusions of the chemist and between 1856 and 1858 spent some fifty thousand dollars in accord with the behests of science in an effort to convert the English ores into steel. I need not tell you the result. Out of that bit of history comes the circumstance that this is the age of steel. In the year 1901 the production of Bessemer steel in the United States alone amounted to seven millions of tons, worth, say, two hundred millions of dollars.

We might in this way approach a hundred sources of human wealth. In the laboratory of the chemist every terrestrial problem is assailed. Investigation goes on forever. No problem, perhaps, has ever been worked out; but many a one, as the problem of iron and steel, has been brought to an absolutely practical solution. The State of South Dakota is a gold-producing State of no secondary importance, but the greatest mining company in the Black Hills owes its whole success to a practical application of a chemical problem, first wrought out in the laboratories of Europe, by which low-grade ores may be handled with profit, as in the famous Homestake mines.

The investment which the world has made in chemical laboratories, and in chemists, too, has been more remunerative in dollars and cents than anyone of us can possibly realize. If the alchemist did not find the philosopher's stone, modern chemistry has at least filled the world with wealth. The plain fact remains that every art and every industry now in vogue among men will at some point, if not at every point, gladly acknowledge its 
obligation to the recent science of the world; the art of the dyer, the art of the weaver, the art of the metallurgist, that of the toiler in wood or stone, the art of him who tills the soil until Dakota is the granary of the world, - everywhere, in every industry practiced among civilized men, that which is newest is best, and that which is best is the outcome of recent research.

But by far the greatest part of the debt of science to the world is paid in service. Apollo must needs guide the flocks of Admetus. "Whoever will be greatest among you, let him be your minister." But even here the wealth of material, which rises in illustration, makes pertinent selection difficult indeed. Everywhere science serves: discovery passing into invention, research resulting in appliance.

Modern electrical development is the triumph and boast of the age in which we live. It is as yet in its infancy only. We as yet simply know nothing about the possibilities of the force which stands revealed in light and heat and electric stream. Our knowledge of electricity dates from the laboratory of Michael Faraday, who was supported by the Royal Institution of London. A few thousand pounds on the debit side; but who shall estimate the service which this single achievement of scientific research has already brought to mankind? Rich and poor alike share in its benediction. By it the laborer passes to his toil; before its light the darkness of midnight flees and cities dwell in perpetual day. By it the miner drives his drill and with it lights the walls of glittering ore in brightness that far outshines Aladdin and his lamp. By it we hear the voices of distant friends as 
though they spoke beside us; by it the nations of the earth are drawn together by instant communication and mutual understanding, and have even now entered upon a merger that shall never be dissolved. The ticking of Marconi's wires across the ocean wastes in a stillness unbroken from eternity may yet usher in the reign of universal peace. What expenditure of dollars shall reckon up a service such as this, or to what value will you liken it? Had men gone to the gods for gifts they had never framed their lips to ask for half so much; nor had it entered into the heart of man to conceive such richness in comfort and joy and blessedness - as at all among the possibilities of this terrestrial life.

But this is only a glimpse of what physical science has done or is doing for our world and in the most direct and tangible ways. Biologic science has been in its way equally munificent. In 1889 the German government subsidized the optical workshop of Carl Zeiss in Jena that he might perfect a glass that should enable the microscopist better to do his work. The consequent perfecting of microscopic lenses, taken with a fortunate contemporaneous discovery of the delicate application of the coal tar series of colors, has made it possible for the student of life and its processes to enter upon investigation with a thoroughness that, were it not so familiar, would appear nothing short of marvelous. Not only do we better understand the structure of all living things, - we have to-day even a pathology of the white corpuscles of the human blood, - but all the phenomena of life itself are so clearly understood that we condition its manifestation almost as we choose. The very minutest forms of 
life are before us and we have learned - 0 strangest chapter in the book of knowledge! - that these minutest microscopic things are intimately bound up in everything else that goes on beneath the sun.

They bring bane or blessing, life or death, and surely not the least service which biologic science has in these late years conferred upon humanity is to be found in the comprehension and mastery of some of the most terrible diseases that have ever vexed the race. In 1854 Asiatic cholera swept the whole country, away up the Mississippi valley, not sparing even the poor prairie settlements of early Iowa. In 1869 the same dread malady threatened us again. The whole nation was in fear. I was but a youth in college and our president, good man that he was, sought to reassure us. He read us the ninety-first Psalm: "Thou shalt not be afraid for the terror by night, nor for the arrow that flieth by day; nor for the pestilence that walketh in the darkness; nor for the destruction that wasteth at noonday; a thousand shall fall at thy side and ten thousand at thy right hand; but it shall not come nigh thee," - and we were all, if possible, more frightened than before. We were not reassured, we were alarmed. We saw no comfort in the thought that a thousand should fall at our side and ten thousand at our right hand; even if individuals were spared, a large population would be swept away. Yet this was the best we could do: be brave, be truthful, do righteousness and escape. It never occurred to us, that we need never have cholera at all; that cholera could be checked, yea absolutely suppressed, stamped out, if men were only wise. Men were all their lifetime subject to bondage 
through fear, and the plague or the cholera or the black death swept them from the earth in millions. But who fears cholera now? Even yellow fever is controlled and will one day be eradicated even in its miasmatic haunts. Our appeal is from dirty Cuba to clean Cuba; from filthy Porto Rico to Porto Rico washed and redeemed. Twenty years ago seven per cent of mothers died of puerperal fever, and the mortality in diphtheria was seventy-five per cent; to-day the mortality among mothers is said to be less than one-twentieth of one per cent and that of diphtheria less than seven per cent. And who shall estimate the incalculable service rendered to the world by antiseptic surgery: gangrene has been well-nigh banished from the hospitals of the world and surgical operations are every day performed with absolute safety, which in days past we had never dared dream of undertaking.

These are some of the ways in which modern science repays the world for her cost; these are some of the visible, tangible dividends shared in by everybody, and to greater or less extent patent to us all. But there is another side of our modern human life where the contributions of science have been of no less tremendous moment. Great as has been the service of scientific labor in the world of industry, the world of economies, the healing art, even greater yet has been its influence in the world of thought. We are too near in time to estimate this service at its full, but as a matter of fact, the contributions of modern science to human thinking have been not only immense in themselves, but in all other lines of intellectual effort have been, as we shall see, absolutely revolutionary. 
The great fact of human development is the march of mind, the problem of the ages has been the quickening of the human spirit. History culminates in those particular periods when large numbers of men become suddenly conscious of some new aspect of truth, some new view of their own relations to the world, to each other, to the universe entire. The coming of the Christ was such a period. The renaissance was such another period, and we who have lived during the last forty years have been passing, all unconscious it may be, through another period no less wonderful in scope and influence upon the future. I believe that when the historian of the years to come - a much-contemplated individual, it is true, to whose judgment we perchance too often make appeal - when that future historian comes to list the great turning-points in the history of human thought, he will name the greatest of all, of course, His coming from whom our era hails; then the taking of Constantinople by the Turks in 1453; then the publication of Darwin's "Origin of Species" in 1859. Certainly no other modern event has had such pronounced effect on every phase of human thought. The aspect of nature suggested in Darwin's book has affected in profoundest fashion everything else: literature, education, philosophy, history, art, religious faith. Let us consider this just for a moment. Putting aside now the vast volume of literature dealing with the topics particularly involved, think how almost the entire energy of the enlightened world has been turned for many years to topics suggested by the scientific impulse. Even those who affect belles lettres pure and simple are not uninfluenced by the common sweep, from Browning, and 
especially Tennyson, to John Fiske; from Daudet to Tolstoi and Maeterlinck. Without modern science "In Memoriam" could not have been written, nor could Maeterlinck have ever dreamed of "Destiny." In education, to say nothing of the place which scientific studies have in the curricula of the world, we may note the almost universal adoption of the so-called scientific method, the laboratory method, a leaven that now leavens the whole lump. Even the law, in all the better schools of our country, is now taught by the study of cases, as the naturalist studies types, cases that have been presented and passed upon by the great courts, and the principle of the law is deduced from the conduct of decisions. And what shall we say of child-study and the entire effort of recent educational theorists who base all hope of educational progress upon the knowledge of the natural history of the child? The child is recognized as a part of nature, and the effort is making to bring him into harmony with nature.

In philosophy the revolution has been yet more remarkable, more absolute, and more complete. The oldtime metaphysics, based upon introspection only, has disappeared. In the older sense there is almost no philosophy, save as presented in the history of successive schools of human guessing. Not that there is no philosophizing: philosophy has been lost in psychology and a dozen other things, and psychology, when scientific, is little else than physiology, the physiology of the nervous system, with definite experimental study of the special senses, such mapping of the surface of the brain, in fact, as our knowledge will permit; with hopeful expectation of a 
comparative psychology in which the primary forms of human mentality may be compared with the psychological processes discoverable in creatures at our feet; or, philosophy finds exercise in the deep research of theoretic chemistry or physics where atoms and ions are marshaled, flitting to and fro in armies, myriads, all in a world so real yet unseen save on the horizon of the intellectual eye. Strange as it may seem, nothing so kindles the imagination as physical research. Says Professor Trowbridge, recently: "There is a path of human inquiry, which leads somewhere into the open, but that path is into the world of the infinitely little." But the infinitely little we may never hope to see, or weigh, we may realize it only in the realm of thought - and it does appear as if the constitution of the physical world were yet to be seen, if seen at all, mirrored in the clear deeps of the human soul.

On the ethical side, sociology and all the various phases of economic science have fairly filled the field, supplanted even the ethics itself of a dozen years ago. But the contribution on the part of science here in method, the analogy in arrangement and presentation of fact, or the derivation of general laws from instances established, constitutes only the smallest part of the real obligation. The great advance which all forms of social and historical study derive from modern scientific influence comes from the changed point of view, a change as great or even greater than that induced by Copernicus in the science of his day, and in fact not unlike it. He shifted the centre of the visible universe; we, anthropocentric in our conceit, who fancied ourselves in the centre of all 
worlds, find the whole race instead swept on, part and parcel of an endless flux, whose origin we know not, whose issue must be good and good alone. Good is here, and science knows no retrogression; only the further perfection of that which has been approved. The great contribution of science is the law of growth, more or less obscured perhaps by the term evolution, but a fact nevertheless, which has found acceptance in every intellectual workshop of the world. We discuss the growth of institutions, the growth of art, the growth of nations, the growth of worlds; even the "Kingdom of Heaven" is like unto "a grain of mustard seed," a living, growing. thing. The universe itself becomes an unfolding flower, blooming by time's eternal stream, and sunlit by a glory of harmony and order and beauty.

This new concept of things that are made has changed, in fact, the outlook of the world, the possibilities of the world as we see them, the very hope of the world. It will serve to prevent, we trust, forever, that strange tendency which has marked every preceding period in human history, a tendency to lapse, to become acquiescent, inert, moribund. Philosophy, literature, religion, even our own Christianity - all tend to sink to one dead level of mediocrity, and to stay there through a thousand years. But a growing thing may not so cease. Not only has life by no means reached perfection, it will reach perfection never. Our modern conception of the world demands an infinite future. And yet in the organic world, every new characteristic as it appears has before it the possibility of a perfection in its own direction; that is, perfect adaptation to all terrestrial conditions. Once the 
vegetation of the earth perchance was all in form of simple cells. One-celled plants made up the gardens of the primeval sea and terrestrial plants were none. But the fact that those one-celled plants could yet divide made possible a plant of two cells, of myriad uncounted cells. Once the world of plants was reproduced by onecelled spores alone; but the spore in its development might not rest until it should form part and centre of the seed. Nor less the seed could it be perfect until for its own sowing, dispersal, provision had been made and even nutrition for the young embryo that it bears. The world of animals now appears, and once the relation of the plant to the race of animals attains full recognition and the leaf - the sporophyl - is changed again; rest it may not until it breathe with odor, blaze in color, or bewitch in endless shifting form-become, in fact, a flower. The flower may not cease along the strange pathway of its creation until its intimacy with some single creature - a wasp in the case of the fig, a humming bird or a moth in the case of the orchid or the yucca - its intimacy becomes so absolute that neither can exist without the other; we have symbiosis, and differentiation is limited by its own perfection. And so our science bids us well perceive that if humanity has been the culmination of all our mighty past, and no one questions that, that is a fact, then the only possible outcome of our human future is the perfection of man in those his peculiar characteristics which are yet manifestly incomplete; and since it is evident that for long ages differentiation has been less concerned in the modifying of man's bodily structure, we are obliged to conclude that his future history 
must be psychic, its only limit psychic perfection in all its wonderful outgoings and infinite possibility of existence and expression, an ideal condition in all that we know as the most lovable, spiritual, and best.

Human perfection, for example, lies not in individualism but in some form of socialism, since the ideal man is related to his fellow, and his evolution will be complete only as his relation to his fellow man is that of perfect harmony, - that is, of perfect love.

The highest gift of science is, therefore, an added hope, a new impulse to human faith. Science is optimistic in the extreme. The golden age is yet to be. For the older civilizations the age of gold was always in the past; but the pessimism of that thought brought all the old empires to wreck and ruin. Christianity attempted to remedy the mischief by recapturing the golden era as an article of faith absolutely essential to the highest conceptions of God, and the highest possibilities of man; and now in these later days, comes our boldest speculative scientific thought, demonstrating that as a fact, the golden age has always been in the future, that every present is a golden age to that which has gone before; we have caught the equation of the terrestrial order, and every fixed point known proclaims a curve whose sweep is not downward, nor backward, but upward and outward and onward to limitless perfection.

There is no such thing as a level in scientific thought or effort, no more than there is a level in a tree; nothing creeps, everything rises or disappears. Every advance has infinity for its own. Suppose the dictum of science had been, as once it was, that all the various forms of 
life were but temporary things to be swept presently from the earth in one dire catastrophe - what sort of a message had that been to the groping sons of men? We should be simply haunted by a perpetual expectation of disaster, compared with which Mount Pelee's shaking were but the falling of a leaf; Mount Pelee's shaking is but the falling of a leaf, - no more. The history of creation as revealed in sea and shore, in valley and in mountain, in quarried rock, in furrowed plain, nor less in the unfolding of every flower, teaches us "to believe what the years and centuries say as against the hours;" "that around every circle another can be drawn;" that there is no end in nature, but every end is a beginning; that there is always another dawn risen on each mid-noon.

In view of gifts like these, those other benefits that were mentioned first entirely disappear. We care no more for iron or steel or even for the riches of the Homestake mine. Without the libraries of the past, here then are philosophy and humanity far transcending the dreams of poet or of seer. Without the plastic forms of art, here are vistas of the natural world that tax imagination to the utmost and fill the mind with visions of a tapestry wrought in the loom of time; without a formal system of ethics, here is the shrine of truth; without a formal system of faith, here is substantial basis for all faith, and the sure foundation of unflinching hope.

The famous phrase of Tyndall, as to the promise and potency discoverable in matter, was something more than an alliteration. Every form of matter possesses peculiar potency; it is for science to solve its own especial problems, but in so doing it is this potency that we ever more 
encounter. The discovery and application of power men say is practical; but as it now appears such practicality is but an incident. It is our own high thinking that is practical. "Who telleth one of my meanings is master of all I am." And so man becomes at last the "mouthpiece and interpreter" of nature, and while the stars in their courses serve him, he alone may hear and lend significance to their eternal song.

And now, ladies and gentlemen, here assembled, it is my privilege to announce this beautiful hall formally devoted to the purpose for which it has been planned. I dedicate it to the use of these professors of science, who in patience have so eagerly watched its rising walls and whose convenience it must so admirably subserve; I dedicate it to the students of the University of South Dakota; to those present and to those to come, that it may be to them the convenient means of obtaining ever new and higher views of the "great truths of nature and the laws of her operation," ever new and higher inspiration from a personal contact with the truth; I dedicate it to the people of this great commonwealth, whose liberality this day reaches fullest consummation, to them and to their children, that the work done within these walls may make for spiritual uplift, for the perpetual intellectual life and saving of this State, in influence wide as these limitless prairies, in beneficence rich as the recurring harvests of all these fertile plains. 


\section{THE RESPONSE OF PLANTS}

I have no doubt that to many of my readers the title of this chapter will be taken as a figure of speech. "Plants responsive?" they perhaps will say. "Who ever heard of such a thing? We should sooner expect responses from the planets than from plants. The people on the planet Mars are no doubt digging ditches for purposes other than irrigation, and the wireless shall yet signal them to some intelligible response, but plants why, Linné himself, the spiritual father of all such as study vegetables, Linné has said - 'Stones grow; plants grow and live; animals grow, live, and feel'; plainly to indicate that sentiency, ability to respond is the very prerogative of the animal. To assert the response of plants is heresy; it is but to introduce confusion; to unsettle our knowledge; induce intellectual discomfort, or intellectual activity which, for some people no doubt, is just the same. Plants exist, indeed, the dull stems and leaves of wood and field; yes, live and manage to grow, poor things, in some far-off uninteresting way; but as for response, there certainly is none. We agree with Mr. Lowell - 'How can one keep up a dialogue, with a dull wooden thing that must live and must die a $\log$ ?' Whispering trees and oaks of Dodona exist only in the realm of fable; and only in poetry do we hold converse with the flowers."

Nevertheless, there are other things besides logs with 
which we betimes fail to hold communication. Sometimes the failure comes through lack of suitable medium - lack of language, we say; more frequently through lack of sympathy. All sorts of speech-perfection fails to enable the coal-barons to understand their employés; nor does the boy fail for lack of language to communicate with Towser. Sometimes there is absolute failure on our part to appreciate the message. Response there may be, to us all unperceived, strive we never so hard. Marconi's messages are possibly flitting at this moment far above our heads, secrets inviolate. But stranger still, there may be a thousand responses, all about us, to us all unnoted, unperceived, simply because they are not ours; they do not come addressed to us; we are in no wise related to them; they come not within our circle; their flashes illuminate never the limited recesses of our unheeding brains.

Now with increase of knowledge some men have learned to think of plants as very wonderful things, next to animals the most marvelous that come within our ken, perhaps so far just as marvelous; for could we comprehend one we might the other. Nay, they are more marvelous, because more hidden from us; voiceless are they, and yet their responses form part of the harmony of this world, part and parcel, no doubt, of the music of the real choir invisible. These responses we may only in part discover because to our senses, our unaided senses, they make small or no appeal. The highly differentiated nervetracts which we denominate the organs of special sense are set in these bodies of ours simply to do a certain sort of necessary or essential work. We awake to conscious- 
ness to find ourselves the glad and fortunate possessors of the faculties of hearing, sight, smell, taste, and touch, and the world stands all related to us through these several channels of appreciation. We are apt to think these infallible. The philosopher lays down as one of his postulates, or did once, the demand that we may not discredit the evidence of our senses. The postulate was just; but alas, as we have long since learned, only within the limit of nature's purpose. These senses of ours, "intelligencers," as Charles Lamb calls them, are guides not infallible - but simply reasonably safe in enabling us to make our way about the world. These eyes of ours were never intended primarily to behold the diminutive objects that fill the field of the microscopic vision but simply to prevent our running into objects that might do us injury; the eye of the vulture scans a wider horizon, with perception still more keen; our ears, not to hear the harmonies of Beethoven, but simply to perceive those dangers whose oncoming possibly produced noise; and so with all the rest. I venture to discuss all this more particularly, because people are apt to think that our senses involve much more in the field of our complex mental, or intellectual, life than they really do. On the theory here adopted they are all reducible to simple touch, to the faculty of receiving impressions from without, and differ only as they lend themselves to impressions of different kinds. The history of the development of the individual sense, no less than the comparative study of sentient animals, abundantly establishes this view and we may here assume its truth.

But there is still another singular fact that we must 
notice before we are in position to understand what is meant by the term response, and particularly before we can apply that term with accuracy in dealing with living plants. The impressions from without to which our senses make response are, after all, as we have lately learned to know, all the result of some form of energy of some form of force, perhaps of one form of energy acting under different degrees of intensity. Thus the perception of sound is resultant upon the reception by the ear of certain waves, impulses, which we may set in motion and measure at our will. The perception of heat is conditional upon impulses, similar, though vastly more refined; the perception of light, upon waves of impulse whose average length is measured in fractions of a thousandth of an inch; but in every case touch, sight, hearing, the sense, the cognition or recognition, is conditioned upon physical impulse, upon something that can be estimated, weighed, or measured. Now we say that our fingers respond to the presence of heat, our ears to sound, our eyes to light, and we perceive that in every case the response is a result of the impact of physical force. Waves beat upon the surface of our bodies and we feel them; waves beat in soft lapping measures upon the outspread auditory nerve, and we hear them; waves dance in brilliant sequence on the retina of the eye, and lo! we see!

But this is only one-half the problem. A response, as the idea is now growing in our minds, is two-fold in nature. We have described only the outside half of it. As the philosopher would say it is both objective and subjective; but objectively it includes here both the cause 
and at least the immediate effect. With secondary or ulterior subjective effects we may not now concern ourselves; but the immediate effect, which is the essential part of the response, is the present subject of our inquiry. Now inasmuch as in any perception, say as of light or sound, the promoting cause is, as we have seen, physical and physical only, it is impossible for us to conceive of the effect in any other light than as physical also; so that when we know that the sense of sight, for instance, is conditioned upon the impact of a certain volume of energy delivered, as we say, in the form of light-waves, it is impossible for us to think of the effect in any other way than as resultant in physical change, displacement of some sort or other, all apart from any mental effects that may or may not be involved in what we recognize as the perception of light. In the sense of taste the approach and reaction are chemical; the form of energy is somewhat different but the response is in both its elements, both in cause and immediate effect something, physical and physical alone. All our perceptions then have reference to the physical forces by which we are surrounded and all our responses have their initiative in a physical reaction, dependent upon or related to the impinging external force. I who speak to you recognize your presence by the impact on my eyes of one increasing tide of waves that comes up reflected here; you that listen are assailed by yet another tide that interrupts not the first; and the response that is evidenced in your attention, is conditioned upon a physical cause and physical effect, just as really as though I were to toss 
(from the platform) a handful of leaden shot and you should perceive the impact of their falling weight.

I am fully. aware that there have been men to argue that apart from eyes there were no light; apart from ears there were no hearing; but the modern view is exactly the opposite. Without light there had been no eyes; without sound no hearing. The eye is a response to the existence of light-waves; the ear to the fact of waves of sound.

We begin now to perceive what is meant by a response. In a vast and magnificent sense the whole organic world is a response.

Two great factors are before us : first, the world is full of energy in manifold phase and guise; second, organic things are plastic, yield to the onset of every sort of energy and by yielding show response. When we speak to a friend and he replies, explanation lies in the fact that we are capable of producing or controlling a certain modicum of energy which produces a physical effect by which our friend perceives and to which he responds. That a similar address made to a plant elicits no response is due simply to the fact that our relations with the plant have not been such as to render such intercommunication mutually advantageous. We speak an unknown tongue; or more exactly, we start a series of wave-lengths which the plant has never learned to register, no more than we are able, codeless, to capture the electric impulses from Marconi's tower. Indeed it is not to be doubted that there are modes of motion all about us that we know nothing at all about; of some we become cognizant 
through our own devices; modes of motion and of matter concerning which we are ignorant absolutely, simply because such knowledge is not of immediate practical value to our terrestrial life. What do most men know to-day about Becquerel rays, or those other rays recently discovered, not yet named? Nature is a generous mother; but after all, she has put into our scrip just capital enough to convey us safely to the journey's end in comfort; a little surplus perchance for hazard on the road, but not one cent for luxury or spending money. Thus it has happened that with all the natural forms of energy about us, animals have used but few. The force that we call gravitation pulls continually and every animal in his every feature shows response. The winds are an unceasing source of natural power, and animals, not a few, take advantage of their moving currents. Heat, light, and sound are more subtle forms of natural energy but each of these has found, as we have seen, appreciation in the animal's structure. The latest form of energy is that developed by the animals themselves and the interaction here, i.e., between animal and animal, is a matter long established. Now it will surprise you to reflect that to every one of these natural agencies the plant makes response with the single exception of sound, and even this response has of late been strongly claimed. Plants respond to gravitation, to currents of wind - to the currents of water, to heat, light, to electricity, physical change of every sort, and to the presence of animals; indeed, plants are the natural chemists of the world and their chemical responses and activities surpass all human cunning. To all cosmic conditions, the structural re- 
sponse, functional response, if you prefer, is just as definite, just as intimate as in the case of their congeners of the animal world.

Volumes might not suffice to set forth or illustrate the variety of the plant response. Let us for the present note as we may a few cases simply, which may establish the general fact. It will not be possible to discuss even these with any fulness, but we may at least see the outlines of the argument.

In the first place, then, plants respond to the force of gravity. Every one of the higher plants is to greater or less extent, in the axis of its growth, a simple extension of the radius of the earth. The fern, the blade of grass quite as much as the birch, the oak, the pine, the tapering spruce upon the mountain shelf - each and all are subjects of that eternal power that holds alike in place the planet and the grain of sand. The mountain spruce unvexed by storms, erect, two hundred feet in height drawn sunward by the light, held downward by its weight as by a thousand equal silken cords, shines in a spire of conic symmetry the very dream of architectural elegance and grace. The very posture and form of every plant you see is the outcome, first, of what we call its nature, its heredity - accumulated responses of all its ancestors - plus the resultant of gravity in conjunction night and day with meteoric forces from " $a$ " the airts the wind can blaw." The fact is that we are so familiar with the response of plants to gravitation that we have ceased to think the case remarkable.

I have mentioned in that other sentence "heredity" as a dominant factor in the plant's behavior; but hered- 
ity is but a tendency, perhaps best described as the contribution of past experiences. The tendency of the plant to grow upward is due to special causes. This too is a response to be mentioned later on. The point here is that the tree, for instance, with an imperative call to grow upward, grows straight upward on the same principle that the farmer-boy makes perpendicular his flagstaff, or the architect raises straight up his most perfect spire.

I am not now speaking of the fact that plants obey the law of gravity but that they respond to its binding force and yet strangely use it. For instance, while the tree grows erect, roots down and stem up, you cannot make these parts of the tree or plant do anything else, except by obliterating gravity. We have a machine called the klinostat on which germinating seeds are carried slowly round and round in a vertical plane. Here, up and down forever change places, and the poor plants are smitten, so to say, with vertigo and roots and stems grow every which way; but, you take grains of corn and plant them root end up, and the root will go down every time, and the stem will start up; they will pass each other, each turning one hundred and eighty degrees to do it. Take peas or beans that have started to grow and turn them wrong side up, hang them in moist air under a bell-jar, and they will right themselves in a few days, with the certainty of an acrobat. We think it very remarkable that we can tell when things are level; we are rather proud of the fact that we have the privilege of becoming seasick, and we talk learnedly of semi-circular canals and all that sort of thing, but what shall we say 
of these simple plants, that without semi-circular canals - without complicated spirit-levels or any apparatus at all that we have yet been able to discover, are yet able to perceive the direction of the earth's center, absolutely, as if guided by lines of force unseen? Nor is this all. Roots are not absolutely bound to the earth's radii, if for some special reason at a given time another direction would seem preferable in presence of some other overmastering but misguiding stimulus. I once planted certain seeds in wet sawdust in a sieve, intending to clip the advancing root-tips as they came through below. Judge of my surprise, a few days later, on turning the sieve to find that the roots had indeed made their way down and out as I had surmised - but, had immediately turned about and were now growing upward, lost in the sawdust again overhead! They had followed the evidently irritating wires. Truly the plant responds to the law of gravity; but relentless, unceasing in its operation as is that unknown force, nevertheless the plant in its response is in a measure free; uses this cosmic force even when most by it controlled.

In the same way it might be shown how plants respond to heat, to currents of water, to currents of air, or to other varying or constant phases of environment. The response is real, and often surprising both in promptness and extent. Nothing in this field of experiment is more astonishing than the response made, in form of leaf, by certain semi-aquatic plants to the presence or absence of water.

The response of plants to moving currents whether of wind or water is too familiar to require more than men- 
tion. These are natural forces which from the beginning have been, to plants especially, a curious stimulant. These have played the part of common carriers, but against them no law of liability may run. Spores, seeds, the whole plant betimes, takes passage down the wind and generally each goes all fitted to the journey. Long before Montgolfier had ever dreamed of his balloon, or Mountain tried his flying boat, plants had successfully practiced aerial navigation in a thousand marvelous ways. The "cotton" of the poplar floats securely around the world, and the parachute of our dooryard maple descending gives pointers to zeppelin and aeroplane and makes a landing absolutely safe and accurate every time: it grows that way!

But the plant has another response more marvelous more delicate still, matching in the exquisiteness of its refinement the keenest perception among animals even the finest that we ourselves possess, with all our strange complexity of nerve and tissue.

Response with us is largely a matter of sound-perception. But sound waves as we perceive them are clumsy things, tremors of the atmosphere from a few inches to a rod in length. When we go to church on Sunday morning and the great organ sounds, the music actually smites the walls and rafters and sometimes makes the windows rattle, proving, if need there were to prove, that hearing is but a mode of feeling, a part of the sense of touch. All sorts of inanimate things might respond, we think, to impulses that come in waves fifteen feet in length!

The absolutely marvelous organ in the animal body is 
the eye. Light-waves, as we have seen, are the minutest impulses of which we take account. The average length is less than one forty-two-thousandth of an inch. In the animal economy one special nerve is so spread out as to beat in unison with these minute vibrations and we think it wonderful; it is; but to the same vibrations the whole green world responds! The vast area of the forestfoliage, the countless blades upon the outspread meadows of the world, the growing harvests in our summer fields, the unnoted flora of the ocean waters, the floating continent of the Sargasso Sea - all are but one far-spread mechanism absolutely responsive to the pulsing beams of light.

It is as if the whole green world were one vast eye. No wonder it hears not when we call. It is the case of the metaphor of the scriptures: Verily, "If the whole body were an eye where were the hearing?" Response so absolute to light has excluded recognition of those longer waves which stand to us for sound. But the plants go farther yet. Wonder of wonders! The plant is able to accumulate the minutest impulses of the waves of light to the very upbuilding of the organic world. For the animal "light is sweet, and a pleasant thing it is for the eyes to behold the sun," but the animal, even the highest, may live in darkness. Homer, men say, was blind. But to the plant the light is all in all; and has been forever. Away in the dawning of life's morning, Nature from her golden trumpet in the skies blew forth a shimmering blast and sent the waves along the pathway of the sun, and life obeyed, and ever since the world of plants has lived to witness to the 
power and magic of that silent music. Silent to us; who knows what it might be did we have ears to hear!

Few of us realize the momentous significance of this light-relation. Few of us have ever stopped to think that without this the world we know would absolutely cease to be. When God made the world He put the power-plant ninety-six million miles away! That is a long distance; perfectly impracticable, your wisest engineer might say; but green plants have found the wheels for application, the bands are beams of light; and lo, Nature blooms, the philosopher thinks, the historian writes, and the poet dreams!

No more do we realize how very keen is the appreciation of light on the part of the living plant. No doubt the response is absolutely prompt, like that of an instantaneous dry-plate. We might perceive it could we devise machinery in delicacy to match. Everybody knows what certain vegetables do when shut in a darkened cellar with perhaps a single dim window somewhere in the wall: their shoots stretch out in helpless pallor, bending to the light. I found once a potato-shoot more than twenty feet long. The tuber had fallen neglected behind a pile of boxes in the basement of a building. That cellar seemed to me absolutely dark; but away off yonder in the street was a man-hole in the walk through which, by the glazing, came just a slight illumination. The potato from behind the boxes perceived that light and consumed itself in an effort to reach that distant, feeble ray.

A man lost in the mazes of a coal mine some years ago found himself in total darkness. He groped from beam 
to beam, from wall to wall. He could hear; he heard the dripping of waters near and far, he heard the melancholy murmur of the busy world far above his head, he heard the echoes of his own footfall and the cries of noisome bats that struggled with each other in the night. At length he found a single point of light. Toward this he urged his way, climbing a long abandoned shaft - at length emerging to the open day more dead than living. Which more responsive to the beam - the bewildered miner, or the imprisoned plant?

Darwin made some wonderful experiments in this field of our inquiry. The shooting blades of a sprouting grass bent toward a distant lamp which emitted so little light that a pencil held vertically close to the plants cast no shadow which the eye could perceive on a white card. These delicate shoots were therefore affected by a difference in the amount of light on their two sides, a difference which the eye of the trained naturalist could not perceive. "Light seems to act on the tissues of plants," says Darwin, "almost in the same manner as it does on the nervous system of animals." Probably, I dare to add, in just the same way, but far more delicately, and through wider spectral range.

But this is not all. The fact is the plant, while thus exquisitely responsive to the light, is yet after all not subordinate to its power. Certain parts of plants habitually turn from the light. Thus the tendrils of the grape bend away, as surely as its leaves spread to the sun. It is advantageous to the grape to seek support by its tendrils, but why this support should be sought in the background is less evident; perhaps that there be 
less interference with the proper foliage display. The leaves of the prairie compass plant at mid-day stand edgewise to the south; that is, avoid maximum illumination; and many plants, especially in dry regions, set their leaves slantwise to the sun and so control the amount of illumination. More remarkably still, many plants well deserve the name "sensitive." Shelley, as we all know, made the "sensitive plant" famous.

"A sensitive plant in a garden grew,

And the young winds fed it with silver dew, And it opened its fan-like leaves to the light, And closed them beneath the kisses of night."

The sensitive plant is indeed a marvel; but is the wonder lessened when we reflect that hundreds of other plants respond to external stimuli in much the same fashion? The common clovers and sorrels of the fields "change their position as the light of day grows and wanes; they are expanded during the day and fold downwards in the evening." The common locust is notorious in such response. In 1869 when the sun underwent total eclipse the leaves of the locust trees retired with the turkeys that clambered to their branches. The courteous mimosas of the tropics bow as the traveler passes amid their shining ranks, and remain drooping in kowtow for some minutes after he has passed. These movements are primarily, no doubt, responses to the varying amount of light and have only later become amenable to the ruder forms of irritation. Your gentle stroking of the sensitive plant is rudeness itself compared with those finer thrills long since resultant from the onset of the light. Yet again; the light is not all. Plants are 
like good children; they go to sleep at dusk and rise with dawn. The difference in illumination merely gives notice that time has arrived when the plant should act in a special way. Darwin has shown us that if for any reason "the leaves have not been brightly illumined during the day" the nervous little things fail to sleep at night. And away north "where the sun does not set, the transported southern Mimosa still regularly goes to sleep." Furthermore its habits may be changed, so that it will sleep by day and wake by night. Plants brought to our greenhouses from the other side of the world instead of bringing with them their waking and sleeping schedule of hours, actually conform to the dial of the meridian to which they have arrived, and sleep and wake with the local population. Could conformity go farther?

But it is time we turned to another chapter in this argument. The response of the plant to the world of animals is the latest accomplishment of the vegetable economy. So rich, so wonderful, so varied is this response that a whole library might be gathered of books discussing this single topic. The whole array of flowers with all their brilliancy of color, beauty of form, and absolute perfection of sweetness and perfume is but a recognition by the plant that other creatures too can taste the light and know its sweetness. Here is a response to creatures that have eyes and noses. Nowhere color in this world of plants but somewhere is an eye to see it; nowhere odor, but somewhere a nose to inhale its fragrance.

"Full many a flower," you say, "is born to blush unseen And waste its fragrance on the desert air." 
Ah, no! by no means. On other pages in this volume we may discuss the desert; but let us here simply say that the relation of plants to the world of animal life is now in many cases so intimate, that plant and animal have become virtually inseparable. Many insects are winged flowers; or rather many flowers have so far mimicked the forms of the gaudy insect world that we may see them blooming as a swarm of resting butterflies. There is no way to illustrate this fully in our northern climate. The finest illustrations are in tropic lands. Perhaps the most wonderful natural order of flowering plants is that of the orchids; a New York orchid show is worth going far to see. One orchid has been called by the less (or is it more?) reverent Spanish population of this continent, "the Holy Ghost flower"; its snowy outspread petals and extended beak simulate the form of the dove, the emblem of the Spirit. This of course is merest fancy; but the relation of plants and birds is after all real enough. The humming-bird is surely a blossom taken flight, rather is the humming-bird a perpetual prisoner, once yielding to the call of beauty, now bound forever in the fascination of the flowers.

Have you ever watched a humming-bird amid the blossoms? Did you notice him last summer and spy his ways hanging upon the weigela and the lilac clusters? If you did you must have been startled by the suddenness of his apparition. All at once he hovered there; you watched him for a moment, perhaps moved - and he was gone. Perhaps you saw what he was doing, saw him flit, at least, like some swift beetle, quick from flower to flower. What he did there you did not see; he 
is too speedy by far for that, and yet he was by no means playing; every simple flower yielded up its sweet, not much of course, but a little, and the sum of it all feeds the tiny hummer. To understand this you must see your specimen at close quarters, then you find a long slender bill, the two parts applied to form an almost capillary tube in which a hair-like tongue can play; this is the suction apparatus by which the nectar rises to that throbbing throat. But here he is again to-night! How 'like a flash he does come, to be sure. Did you ever see such swiftness? You cannot see him fly, you only note that he has changed position. What a breast is that, and what whirring wings, just a haze; sure no saint ever wore halo such as that! What little wings! How can they go so fast and not break all to pieces? There he is before that great swinging bluebell, stands right in its flaring portal. Stands? - no, he does not stand, his little feet touch nothing, he is balanced there in perfect equilibrium, marvel of marvels! Gravitation pulls one way, wind blows another, little wings beat another, resisting both, and there he hangs spinning like a tiny planet suspended upon nothing. When saw you equipoise like that? There, he's gone again. He heard perchance the squeaking whistle of his mate, or possibly saw you; but think of it; vision, hearing, taste, desire, perception, life, energy exhaustless, all made out of a little honey - "the perfume and supplíance of a minute;" no more. Oh, what a miracle is there, that moves from year to year through tireless generations! The gleaming perfection of exquisite beauty, and ALIVE!

Now then: need we here sound-waves sixteen feet in 
length to tell the sympathy between bird and flower? Think you the bird perceives not in some mystic way the silent music of those swinging blossom bells; nor less respond those clusters of yellow and scarlet and blue to the gentle ministration of that whirring marvel poised before them? Alas! how far we are all of us from reaching the diviner harmonies that fill this wondrous world! Of old, plants have been calling bee and bird and butterfly and moth; of old, the population of the air has heard the call; of old, a thousand flitting, breathing things have sought the very heart of bud and blossom, and more and more the plants have answered back filling the earth with splendor, so that in summer the colors of the rainbow come reflected from mountain and from plain and the fragrance of Eden fills the morning hours, while perfumes from fountains all unseen imparadise even the desert night!

To the animals of this world the plants have long since learned to make reply.

But there is one animal that has only lately, as time goes, come into his possessions. Of this latest child of Nature the Scripture saith that he shall "have dominion over the fish of the sea and over the fowl of the air." Surely the plants are not disobedient to his summons.

"The little flowers were kind to him And the thorn-tree had a mind to him

As into the wood the Master went.",

Plants have responded to man's summons in every possible way. They have come with him in sympathy profound through all his journey, that long, long jour- 
ney, out of the dim and misty past. Some of them spoke to him with their sighing leaves and soothed the early questioning of his perturbed spirit. Some of them spread above his head their leafy boughs in loving shelter; some of them when he fain would worship threw their Gothic arches high aloft, when "groves were God's first temples;"' some of them lent him all luscious forms of fruit; some of them came with him all the way in response to his demand for very bread, from bending twig, and bearded head, and bursting pod: and when at last all other wants supplied - the spirit of beauty, wakened in man's soul, began to cry, plants heard the call; from leafy bower and woodland aisle, with graceful form and petal's blush they came, to furnish forth at bidding of man's choice, a beauty and a loveliness that shall one day deck the earth redeemed. 


\section{THE ALAMOGORDO DESERT.}

\section{The Response of Plants to Changes Terrestrial}

The Alamogordo desert of southern New Mexico lies immediately west of the one hundred sixth meridian, west, and approximately between thirty-two and thirty-four, north. It is bounded on the north by the Oscuro range of mountains, on the east by the Sacramentos, on the south by the Jarillas and the Organ mountains, on the west by the San Andreas. As here defined, therefore, the desert is of comparatively limited area, one hundred or one hundred and twenty-five miles from north to south, and perhaps thirty-five to fifty from east to west; a very convenient little desert, easily manageable, one might suppose, for any naturalist, who, with inborn love of adventure, starts out in search of the wilderness to find scenes and pastures new.

The desert of Alamogordo or Tularosa is a great plain, not unmarked, however, by singular topographic inequalities later on to be described. Only the most casual geologic examination is sufficient to show that the plain floor corresponds stratigraphically with the beds in some places exposed at or near the tops of the surrounding mountains, in any case far up their flanks. On the east especially limestones of carboniferous age rise sheer some one thousand feet or more straight up from the desert floor, and are again capped by other strata only at length, 
perhaps a thousand feet higher, surmounted by materials correspondent with those in the level of the plain. On the west the same thing is true; but more emphasized still is the difference in level between segments of corresponding strata. Here the weird Organ mountains break the horizon by upthrust spires and pinnacles of granite ${ }^{1}$ which to some early voyageur crossing these dusty plains suggested the pipes and architecture of some far-off organ, and the mountains were so named; but upturned granite means that the sedimentary rocks are here further uplifted still than on the eastern side, so that we quickly find ourselves in presence of vast parallel faults and our desert lies thus between their giant walls. It is as if half the region between this city ${ }^{2}$ and New York should suddenly sink two or three thousand feet, or, what is the same thing, it is as if the several thousand feet of difference in level were brought about by the depression of the included area, and the simultaneous elevation of the sides. At any rate the desert plain of the Alamogordo or Tularosa sands is simply the upper surface of a gigantic block of the earth's crust that sank some time subsequent to the deposition of the Jura-Trias and the earlier cretaceous strata of this western world. These strata include, as we know, the famous "red beds" which tinge the mountains of half the continent, the red beds with all their gypsum, marls, and salts of every description. Accordingly, as a result of this faulting, our desert has for its foundation everywhere great fields of gypsum, often for long distances wide-exposed, sometimes thinly veiled by loosened sand,

1 So reported.

2 Philadelphia. 
sometimes deep buried by vast deposits of wine-red marls and clays, or covered anon by the products of erosion, whether by water or by wind. The waters from the mountain snows have brought their débris; the winds of the desert have come with their burden, but nowhere has such transportation traversed the desert borders, at least in recent times; there are to-day no excurrent nor percurrent streams; the winds die along the mountain walls and the waters sink in the desiccated sands.

But this is not all. This great sunken block of earth's crust seems itself to have been cracked again and again; there are secondary faults, and along the line of one of these thinner or weaker places the subterranean energies of the world have some time found emergence. Floods of lava welled up in the midst of the desert, and fountains of fire streamed along the ground, following existent topography for miles and miles, now narrowing to dimensions measured by rods between low ranges of hills, now widening for miles across the broader valleys, only to lie at last a vast field of blackened cinder, slowly disintegrated by the desert storms. This is one of the most peculiar topographic features of the whole desert. As things terrestrial go, this is a recent phenomenon. The age of lava may be measured by centuries, a few thousand years, it would seem, at most. The surface over which it poured was a friable, marly soil. As the floods cooled, the mass cracked and gaped in every direction. Rains descending upon the surface sank to the ground below and shaped for themselves channels. The lava so undermined has fallen into a tumbled mass of weirdness and confusion, indescribable, impassable. 
The lava constitutes one of the features of this remarkable desert; there is yet another. Along the western border, partly by erosion, partly uncovered by the western winds, great bodies of gypsum lie exposed. As this slowly disintegrates the wind gathers the particles set free and bears them eastward; the famous white sands, covering township after township with drifted mineral, white as snow. Vast windrows shifting slowly with every storm, and forever reinforced by the unceasing contributions of the west, mark the landscape over several hundred square miles, unique, intact, forever changing, yet the same forever.

Added to these peculiar and special topographic details of this surprising desert we have, of course, those less noteworthy, the common every-day features of desert make-up : we have mountain slopes, rocky fields and hillsides, eroded valleys, marshy sinks, where lose themselves the vanishing torrential streams; wide plains of marly clay; belts of sand-dunes, red sands, yellow sands, also shifting and moving, but better subservient to the vegetation of the region, these present simply vast fields of low hills or hummocks ten to twenty feet in height, separated on every side by tortuous valleys, winding in labyrinthine fashion, wind-swept hard and bare.

One other topographic feature must be added to complete our picture. The forces of erosion even along the mountain walls have kept pace fairly well, at least, with the changes in level. Great cañons break back even through the hard, encrinitic limestones, dividing again and again where the waters have carved the rugged pathway by which the explorer may now reach the mountain 
summit. The result of this erosion forms a wide talus around the desert, spreading great fan-shaped deposits at the mouth of the eañon, where immense blocks and boulders choke the exit, succeeded by ever smaller rocks and pebbles farther out until at length only the finest silt is swept along from the widened margin far across the almost perfectly level plain.

Now it is evidently needless to say to every wisest man in an ecologically minded audience such as this, that every one of these peculiar topographic features, whether special or not, will display its own peculiar flora. True, this is not always the case; this desert must be studied in its entirety, and it will require months of patient research to even sketch its far-reaching problems. As a whole the flora may be said to be that of our western arid regions generally, and yet, after all, it is not just like that of any other region, north, south, east, or west; not that it has peculiar species perhaps, but that it has its own particular groups of species.

Two factors, and two alone, as it seems to me, determine the phytology of this desert; the one, difference in the constitution of the soil, referable to its geological history; the other, difference in level referable to the same initiative. Thus there is a peculiar flora on the sands whether white or red, another on the silted plains less liable to transportation by the wind, another where the salts emerge, whether in briny springs and fountains or as crystals whitening the surface of the ground; another for the mountain shelves, and still another for their faroff summits. 
The El Paso Northeastern Railway passes the desert on its eastern side. There are two stations on the line where for several miles in every direction the surface is a red-brown sand. One of these stations has been by the railroad people appropriately named Desert, the other is Escondida. The level of the two stations is the same, four thousand feet, and the flora is identical, although the points are thirty miles apart. Each, however, is by itself unique and entirely separate from the other. The dominant species is Yucca radiosa, so much so that these points are called the yucea desert. Of course, the almost ubiquitous mesquite is there and Atriplex canescens and Artemisia species. There are other species to be sure, such as forms of Chrysothamnus and Ephedra, but the plants first named give to the plain its character as far as vegetation goes, and in topography as well: they not only thrive here and come to abundant flower and fruit, but they hold these peculiar sands otherwise driven about the world by desert winds.

Now it is a remarkable fact that the white sands, thirty or forty miles off to the northeast, exhibit an almost identical flora. The student hastens across the intervening desert to meet that shining wall, expecting to find all things new ; but, behold, the white sands are sands first of all rather than anything else. Whatever their chemistry, and they have their peculiar problem for the chemist, only a vegetation that can endure a moving, shifting terrene can flourish here. The white sands form accordingly part of the yucea desert. Their relation to vegetation is almost purely physical, but they exhibit 
some peculiarities. They are gypsum, as everybody knows, ${ }^{1}$ but while they move as other sands, they must be compared with wet sands. The vast drifts, thirty to fifty feet in height, are moist often to within a few inches of the surface, and are so compactly driven that one may walk upon the solid surface with comparative ease. A white wall like to the appearance of marble is moving slowly eastward, whelming all vegetation as it goes, some of which, able to grow through the encroaching mass, persists so that all the plants now appearing on the surface, so far as examined, are anchored by lengthened stems or roots to the underlying older soil. The same yucca that appears at Escondida here emerges sometimes by green tips from a snow-white drift twenty feet in height, or anon, seems to crown triumphantly some lower mound. The mesquite holds on, in some places a desperate fight, and certain species of Rhus, $R$. aromatica and $R$. trilobata, perhaps, maintain a perilous existence out over the whole region, sometimes even on the summits of the highest knolls. These sumacs are the characteristic species of the white sands.

But let us turn north. A journey of fifteen or twenty miles brings us to the black wall of the lava flow. This

1 The following analysis of this material has been kindly furnished me by Dr. L. S. Andrews, late of the Mallinckrodt Chemical Works, St. Louis:

Calcium sulphate, $\mathrm{CaSO}_{4} \ldots \ldots \ldots \ldots .77 .64$ per cent.

Water, $\mathrm{H}_{2} \mathrm{O} \ldots \ldots \ldots \ldots \ldots \ldots \ldots \ldots . \ldots . \ldots . \ldots . \ldots$

Calcium carbonate, $\mathrm{CaCO}_{3} \ldots \ldots \ldots \ldots .0 .95$ "6

Silica and undetermined, $\mathrm{SiO}_{2}$, ete.... 0.86 66

$\overline{100.00}$ 
is a fearful region. The Mexicans call it mal pais, "bad country"; giant floods whose waves are stone, fields and fissures, caverns, holes, pits, and wells, alternating with tilted slopes, knife-edge culms and ridges, make a topography weird, impassable, fascinating because so unapproachable. Yet the mal pais is covered with vegetation. Of course, the vegetation changes, but by no means as one might easily suppose. Here is no new species, no variety of a species, when the desert is studied as a whole. The change is correspondent to a change in level. The lava beds are high, and they are crowned with the flora of their own altitude. We shall meet it on the foothills of all the mountains we presently ascend. Here is no alteration of soil, for the only soil is that deposited by the wind, the lava itself perfectly intractable. Here are the familiar mountain cedar, Juniperus occidentalis; cholla, sometimes twelve or fifteen feet high, where, springing in some ragged well-hole, it seems to peer out above the sooty walls that hem it in; here is the mountain barberry. Even the nut pine, Pinus edulis, has mistaken these pitchy steeps for the clayey flanks of its usual mountain fastness, and now and then rivals the cedar in its hold upon the jagged upturned edges of these flinty sheets. Even the lava-beds have not apparently affected the general character of the desert flora.

At the south ends of these black fields, however, emerge great springs. Here all the plain is saturated with salt and alkali, and here is a peculiar flora conditioned by this fact. The waters emerge almost from the edge of the lava sheets, and tufts of Suceda and Allenrolfia are 
set close against the lava wall. This is ideal; this we should expect and here it is.

The sands and the lava lie in the middle of our desert. If we take these as a starting point and move toward the summit of the mountains, the successive belts of vegetation gradually shape themselves so that we learn presently to identify them by their color. A plain below the general level is gray, grass-covered, with here and there a bunch of ephedra or nopal, no yuccas, no atriplex, no other forms of cactus. As the terrene rises to the silt-plain, thickets of cholla alternate with mesquite 'and the crucifixion thorn; not that other species do not occur, but these are dominant, give to the belt its charac'ter and color. A little further mountainward and we reach the Covillea tridentata, ever in bloom, which lies as a girdle of green and gold around the whole base of the mountain range, visible for miles and marking for us the limits of the talus with an exactness that is remarkable. Beyond the covillea belt come the cacti as the terrene becomes more rocky; Mamillaria, with its species numerous and varied, the unique but widely distributed ocatilla, the prickly pear, often in giant form all these cover the rocky slopes that lead up to the steeper walls of paleozoic rocks. Sometimes, where a shelf occurs, and the bare limestone forms a flat, mesa-like field, the yuccas come back, but not the Escondida form, with Agave parryi, and abundant ocatilla, while in the rocky defile below, locked amid gigantic boulders, now on their tardy journey to the talus plain, the creamy flowers and fruit of dasyliria lift their glorious spikes, the envy and vexation of the photographer. 
The strata of the lower carboniferous limestones now confront us; crystalline, encrinitic, and exceedingly hard, rising often hundreds of feet sheer up and down. But these dry walls likewise have their flora. Mamillaria micromeris matches with its hoary spheres the weathered stone or lights it up betimes with scarlet bloom, and Notholcena serrata fills with sombre tufts every shattered crevice.

But the upper members of the carboniferous are much softer and, amenable to erosion, present a gentler, flowing topography. These slopes are everywhere clothed with oak, not trees, indeed far from it; low' dense shrubs, the so-called shin-oak, Quercus gambellii and Quercus gunnisoni. These two species form pale green belts around the mountains, and are recognized easily, distinguishable for miles. These species indeed form a sort of phytographic border land; all below is desert; all above is forest; for above stands, or lately stood, one of the fairest bits of woodland in the United States, and that means in the world. But this forest is again in large measure conformable to geologic structure, its distribution determined by the history of what lies beneath.

As we ascend the mountain, passing all the carboniferous limestones, sands, chalk-beds, and shales, we presently encounter the "red beds" already mentioned, the most remarkable geological horizon in the country, familiar to every student of our central mountains, noted even by the ordinary tourist, the same wherever found in Utah, Colorado, the Black Hills of South Dakota, and here again in these far-off mountains of the Mexican border, the same vast gypsum-burdened deposits of clay 
and shale and sand. The red beds yield easily to erosion. The washings from their wasted flanks have tinged the desert far below, and reddened the walls of every rocky cañon on the way. Sloping terraces and flat-topped hills afford a soil rocky but not infertile, supporting once more its own peculiar vegetation. Here are still the shin-oaks, it is true, but all overshadowed by other nobler trees; here is Berberis trifoliata, the Texan barberry; here is Pinus edulis, Engelmann's nut pine, and most characteristic and perfect of all, here stands Juniperus pachyphloum, the mountain juniper, great forests of it, ancient trees betimes, all comparatively low, but with giant trunks six or eight feet in diameter; these timedefying cedars are the trees of the red beds. With the junipers, especially as we pass their upper limits and come out upon the calcareous cretaceous swells and plains, occur another oak or two. The soils are now remarkably rich in lime. The waters that fall on the higher mountain levels escape above the red bed shales, but so impregnated with lime that they actually form a new stony deposit often for a distance of many rods about the point of exit. On these calcareous soils stands now the forest, along the very summit of the mountain, nine thousand feet above sea-level, a magnificent forest of spruce and pine and fir: Pseudotsuga mucronata, the Douglas spruce, five or six feet in thickness; Abies concolor; Pinus ponderosa in beautiful perfection of its immortal youth; Pinus flexilis at its very best; a typical Oregon forest six or eight miles wide and some twenty long, crowning the summit of this isolated mountain peak in the midst of the deserts of southern New Mexico, 
for, as everybody knows, these are in general species of the forest of the far Pacific Coast. As one stands now at last thus at the very summit of his problem, and from some promontory rock of vantage looks out upon the vast plain thus mountain-girt, the indescribable beauty of the scene must first impress him. Far to the west lie the San Andreas, the Organ, and the Oscuro ranges, a long low wall, grey and solid, its serrate summits indentured in the azure sky; below, the plain, brilliantly lighted, soft and brown and lucid, save as the mal pais stretches its blackness as a bar sinister across the northern end, while away to the south the gypsum desert seems a cloud of snow beneath our feet, more brilliant than that evanescent whiteness that floats in the deep blue far above the one the strange counterpart of the other; all is so silent, so changeless, and so fair!

But just now we heed not the beauty of the landscape; other thoughts come crowding upon the observer, all equally insistent and impressive. Evidence of enormous physical change thrusts itself upon our astonished attention; not the sunken desert itself alone, that great block already described, but the denuded and sundered mountain walls, the great cañons that stretch back for miles, cut down through even the solid limestones at the mountain base - a process vast and old. Once the cretaceous sea rolled here, and when it retreated here were beds of limestone hundreds of feet thick. Where are they now? Only here and there a remnant on the mountain summit; the desert is covered with their débris almost to the distant sea.

Nor less is one impressed by the slowness of all this 
topographic change. There is evidence of violence, suddenness, nowhere, save in the mal pais, which is local, recent, and does not affect the general problem. The moving currents of the air, the soft ministrations of the summer shower, the melting winter snows, have carved these mountains, are sculpturing them to-day. Those columnar whirlwinds that even now like dancing dervishes chase each other across the plain, are shaping anew the desert; that thin cloud that hangs yonder like a banner from the mountain top is a rainstorm, changing even now the general altitude of the range.

But once again: as we look out thus from the summit of our problem we are impressed with still another fact more far-reaching, more splendid still. The whole living covering of the world, the vegetative garment of the desert and the mountain, conforms exactly to the surface, to soil and level, no doubt with an exactness that we have only begun to guess or understand. There is a mathematical line that limits the distribution of every plant, but that line forever shifts and varies. The topography varies, except the mal pais, by changes so slight, so delicate, as to be imperceptible to eyes unskilled, and with the topography varies its covering of life.

Let us say first that these topographic changes will change the limits of distribution. Once the sands cover the silt plains, and the grasses will vanish while yucca and artemisia succeed. Widen the talus and covillea will stretch farther its golden scepter. But the problem runs far deeper than this. As the face of the world undergoes these delicate, subtle changes, the plant responds in something far more than shifting distribution. A plant, 
as every student of botany well knows, is the most plastic sort of an organism in the world, responding in every sort of way to its environment. We who study the microscopic structure of the humblest plants understand the limitless possibilities here. When we reflect that the suppression of a single cell at the critical moment may change the direction of an axis or alter the contour of a leaf, it is hard to set too high an estimate upon the possible response made by a simple plant to environmental variations, however delicate. We who study the physiology of the plant, peer into its changing cells, and strive in imagination to reproduce the marvelously intricate reactions - physical, chemical - that forever shift and play within those narrow limits - we need not be told that every vegetable cell has in it opportunities a thousandfold to match and meet all the subtle changes suggested by the slow-creeping but implacable forces that work out the physiognomy of this time-worn earth. A little more calcium here, a little more phosphorus there, sulphates, nitrates, and the rest, and the thing is done. Nay, when we even think of the form in which all energy comes from yon distant sun, and the delicate machinery on which it plays, we need seek no further occasion for the intervention of every sort of outer cosmic force. Not a tree on all the Iowa prairies but shows in its every lineament, in its very expression, a response to the Iowa environment; and so, we may be sure, every desert plant records in its present form and stature all the affirmations, all the responses it has made in all the centuries to the bidding, the silent bidding, the most gentle coaxing, of the world external. For, note you, the call for 
change at any given instant has not been great; the slow upheaval of these mountains, their peaceful gentle removal by the winds and rain; that is all; that has changed and is changing the living world. Where the terrestrial call is rude or sudden, response there is none. The lava beds show no single characteristic species. Their flora is simply that of their own rocky level. Nor could here any sudden initiative on the part of the plant avail. The adaptation is absolute now, and to vary save as the environment varies would simply invite disaster. As well the tadpole suddenly assume lungs or the lizard put on feathers.

Nor is this all. Our desert as it lies shining here before us is but a fraction of that wider, vaster desert that covers all the south and west. Across the Organ and San Andreas yonder is another desert exactly comparable to that we study; all Arizona, southern California, Sonora, Chihuahua, much the same; here and there a mountain summit tufted with forest, western in type, high slopes thinly clad with stunted juniper, benches of covillea, wide low plains covered with mesquite, with yucca and cactus and all the less noble plants that stand between; and our problem widens, becomes vast as the continent, and any answer that we make must be farreaching as the flora of a world.

Our desert lies shining here before us; but not one of these plants except the cactus is in broader sense unique; each has its kin rising in happier fields to fairer fortune. The yuccas are lilies, but lilies bloom in Bermuda and in Teneriffe, and in every most fertile garden of the world. The mesquite is a prosopis, but the genus Proso- 
pis shows many a handsome forest tree, and even the mesquite in the Arizona Valley, where conditions are less hard, rises a forest with trees fifty feet in height. The cactus, as I read it, with undifferentiated floral leaves and abundant sporophylls, is an ancient adaptation to an ancient desert, possibly pre-cretaceous, and takes possession of the world just so fast as the world becomes desert; unstable in cultivation, not because new, but because reversionary.

I do not mean to say necessarily that the Alamogordo desert flora has had its origin where it stands, although such a contingency is not impossible of thought. Had this been the only desert on the continent its flora is as might have been expected. But there are a hundred similar intra-montane regions whose geologic history is the same. These have in similar fashion orginally shaped a flora each for itself. No doubt once similar conditions are set up in regions at first unlike, an exchange of species may take place. American cacti are at home in the deserts of Europe, and the Russian thistle flourishes on Dakota plains.

The desert lies shining here before us, changing forever, but all its changes are of imperceptible delicacy and slowness. Its methods would seem not different from those by which nature has from the first essayed the education of the vegetable world. Between salt water and fresh all conditions offer by infinitesimal shadings where the rivers meet the sea, thus green plants first emerged from ocean; all conditions from shore-line lowwater mark to dry land; thus the plants at length sat on the shore, wet only by tides or by the gentle rain; all 
conditions of level by which the plants occupy the kingdom of the upper air; all conditions of spore-union by which they meet at length the problem of aerial fertilization; so that while sports there may be among plants outside the pale of civilization, nevertheless they must always be within limits set as result of more gentle changes effected by the slow, and, for the most part, exquisitely delicate transformations which make up the history of the planet. Given a desert flora, a cactus flora, for instance, and there may be endless species-making, by sport if you will, or otherwise, but in every case a cactus; but the cactus itself is the child of continental movements which brought about some old-time, perhaps cretaceous desert.

Our desert lies shining here before us; it is old and silent: would you know its secret, read the rocky records that lie behind, around, beneath, and be assured that once the story of yesterday were understood the facts of today would ask no greater explanation. The physical forces of this world still drive the loom that weaves the web of life. Before the loom the unseen weaver sits, guiding her web that passes to an endless roll, changing withal the width, the pattern, as conditions rise. Changes her arabesque, it is for cause; changes it not, it is alike for cause; and if at intervals as we watch, anon new figures rise, may it not be but the return of some earlier triumphant cycle that here begins anew, evident enough in cause and feature were once that giant scroll unrolled, or were her watchers more patient, more enduring. Alas, in presence of that mighty loom what fleeting, evanescent interpreters are we! 


\section{THE PLANT'S RESPONSE}

\section{The Response to Human Agency}

The response of plants to human preference, plan or purpose, is such a matter of fact that most people overlook it altogether. In a thousand ways we take things as we find them. We never think of origins, nor have we any sense of obligation, no more than that which may stir the breast of a robin feasting upon the proverbial early morning worm. No doubt the life of a man is dependent upon the world of plants quite as much as that of the robin upon the world of earth-worms and fruits, but neither man nor robin concerns himself very much about it.

Now in a certain sense this is well. Why should we concern ourselves about the boundless beneficence of what we call Nature? The robin, should he reflect at all, might say: "What a magnificent world is this! I awake in the morning; the air is sweet and pure in moving oceans all about me; my wings are free; I sail unconsciously upon the morning wind as boats sail on the sea; trees stand everywhere, my island landingplaces. I feel an inclination to fill my mouth with something soft and sweet and lo! the earth teems with juicy things that meet, exactly meet, my need; yonder the cherry stands in brilliant dazzling scarlet, crying out in the very speech and dialect of the whole robin tribe: 
Come eat! Come eat! What a wondrously fine world is this! How perfect its adaptations; it was no doubt made expressly for robins; the earth-worms writhe and crawl for us; for us the cherry-tree glows in summer scarlet, and the blackberry spreads its harvest; I will hie me to the summit of yonder waving elm, built to protect me, stretching its leafy arms to hide my nest - I will hie me to its summit and will sing and sing and sing!"

The robin reasons well; he reasons, you may notice, exactly as do men; as men have done through all the centuries; it must be well. Nay rather; he reasons as have reasoned the more thoughtful of mankind: "Plato, thou reasonest well." And yet, we who look upon the situation from without may easily perceive the robin's limitations. Possibly the earth-worm exists for his own sake after all; and the cherry-tree - a word from the farmer not only spoils all this the robin's specious argument but may even silence forever that early morning song. Where then is all our harmony, our beauteous adaption to purpose, and plan of this created world? Alas for robins and for men, it lies far deeper; we are just now beginning in our later thoughts to see something of the trend and purpose of it; to find it more profound than all our learning, wiser than all human thought. The trouble in these things is with men as with robins; the view is not wide enough; research goes not far enough; we follow our little lines and think them ended when we lose them; we light our little lamps and eatch their glimmering reflections on the world about us, but forget that only infinity can comprehend infinity; that only an infinite ocean can return the light of perfect, to say nothing of absolute truth. 
But let us go back to our cherry-tree and our robin. When it comes to priority of claim it is probable that the title of the robin far outruns, and would, if fairly presented, hold in any court in Christendom. Cherries, in the first place, are in response to the keen eyes and fairly keen taste of birds. Wild cherries there are in abundance; made for robins; but the robin meanwhile has played his own part in the making of them. There, my friends, is where all our reasoning hitherto has failed us. We have failed to realize the part that robins and men play in their own destinies; content in the assertion that "in the beginning God created the heavens and the earth," we have failed to perceive that in his infinite wisdom robins and men are alike co-workers together with him in the sublime emprise, - that in the result, as hitherto revealed, all things organic are in greater or less degree participant.

The storage of a minute modicum of starch or sugar has from the beginning been of advantage to the germinating plantlet which is of course the essential part of the seed; but such store of starch or sugar is also a prime element in the food of animals. These accordingly early learned to feed upon vegetable seed or fruit, and in so doing lent their aid to the dispersal of plants over the habitable earth. Now plants are great expansionists. Those whose seeds spring in the greatest number of localities are more likely to persist. Hence the consumption of the plant-fruit by animals is an advantage, provided only the germinating power of the seed survive. The food of the robin is therefore at once a response of the plant to a condition; a bit of strategy on the chess- 
board of Nature to prevent check-mate. The thickening and hardening of the wall enclosing the embryo was the first move; the sweetening and coloring of the outer cover of the fruit, the second. That is, - granted that the animal's service is an advantage, then it is evident that that plant will receive more frequent service which proves to its serving visitors more attractive. The sweeter the cherry up to the limits of the bird's appreciation of sweet, and the more clearly contrasted against the foliage of the tree, the greater the number of visitors, the more wide the dispersal of the seeds.

This gave us the wild cherry of all forests, and is the limit of differentiation, as between bird and fruit. In the old world the wild cherry is native of central Asia and its small sweet fruit is black or white. Now comes the agency of man. If the cherry has responded to birds, much more promptly to human selection. Edible cherries were found on the tables of the Greeks and Romans, and have not in all the centuries failed us until now, when the thick-pulped black and white cherries of California are carried around the world. Our sour, common red cherries are derived in similar fashion from another very similar Asiatic stock; but, somewhat more enduring of our valley climates, are more widely known, and when the robin lights next amid the shining spheres, reflect; - he is there but to take his own, to collect an ancient royalty. Robins and birds were horticulturists ere Adam delved or Eve span.

The agency of man in this process which I have taken as illustrative of all the fleshy stone-fruits is therefore but supplementary, accelerative. The birds evolved the 
cherries; man has carried the idea forward to meet his larger mouth, and, better, his finer, more discriminating taste. The birds were content with small cherries; men love big cherries; to which the birds do not object. The part played by man, accordingly, is not to make or unmake cherries: but simply to forward a process already under way. Dr. Geddes illustrates the matter thus: "You have two dozen apples in your fruit-basket just beginning to spoil. Each day you take the two best, and at the end of a few days or of a week there are ten rotten apples left. To a slight extent, it may be said, you are responsible for the growing rottenness, for you might have periodically selected the two worst, but the rottenness was there; it not only arose, but increased without you." Now this is true in the case of most of the plants that have responded to man's enticing, but not of all, as we shall see. But in general it may be said that in all the intercourse of plants with men as now discussed, the plant has spoken first; has given the hint and it has been the wondrous, the delightful duty of human genius simply to elicit the fuller, more complete response.

The origin of the cultivated grasses is no doubt similar, although, in most cases, the association is so very ancient that all trace of the original form and type is lost. Thus wheat appears to have been much the same as now as far back as the earliest records of humanity. There is no wild wheat in the world. The original type is lost. In the records of China wheat is described 2700 years B. C. as a gift of God to men; its origin was lost then. In the earliest Egyptian hieroglyphs wheat appears 
to find a place and its sowing is portrayed. Nay, what is true but stranger still: in the débris of the lake-dwellings of Switzerland and Austria, some of which are certainly prehistoric, grains of wheat are found in abundance, like the existing forms but smaller; so that so far as the record shows wheat is an exceedingly ancient response to human selection. You have heard of mummy wheat; that grains found in closed human hands of some old agriculturist, some lover of seeds and their mysterious hold on life-you have heard that such seed sown, grew apace and confirmed so far the Egyptian faith in physical immortality. But, alas, the story is but a touch of fiction. There is no mummy wheat, nor has any grain of any kind from such a source been ever known to grow. The Arabs of Egypt have heard the story, and, willing to accommodate the credulity of the tourist, offer mummy wheat to every passer-by. Not seldom the grain is Indian corn sent from the farms of Iowa and Illinois! Wheat there was in Egypt ere ever Joseph stored the harvests of the fruitful years, but no mummy has brought it living in his dead and withered hand down to this wonder-loving modern world.

The story of many other grains is not unlike that of wheat. Research finds them in the possession of prehistoric man; but the original type has vanished. But what do we not owe to those old-time gardeners and farmers who were skillful to select and care for, and finally transmit, these wonderful grasses, enabling you and me to feed upon the finest of the wheat? How strange it is for us, even in imagination, to thus look back into that ancient world, of which otherwise no record 
exists whatever. Look back with me into those dim fields and see the first agriculturist sowing his first crop of primeval wheat. What a step was that in the history of humanity! How timidly he must have essayed his work, copying the winds. Wasteful man, easting away his meager store. How must his faith have been sorely tried ere ever the seed could grow! No voice had then proclaimed to his encouragement, "Cast thy bread upon the waters, for thou shalt find it after many days." Then, with what interest he saw the harvest rise, "first the blade, then the ear, then the full corn in the ear." Then the harvest; look, my friends! The light is dim, but you can see him, a dull, brown, little figure moving over the brown fields in an atmosphere that seems fragile with antiquity, bringing in the earliest ripened spikes, the first fruit of his own sowing. Was ever triumph like unto that! That one harvest made possible the civilization of the race. "Behold a sower went forth to sow!" There he is again; far yonder on the distant hills, in the light of humanity's morning, he and those who walk there with him. How little do they forecast and know! What state of mind was that, when to a human soul lay yet undiscovered the one universal truth, "Whatsoever a man soweth that shall he also reap!"

In this original research work of the race all sorts of primitive men took part. One of the wonderful things about the Japanese to me, is the remarkable list of cultivated plants which these antipodes of ours have coaxed up out of the world of vegetation around them. They have cherries but they are not ours, they have plums chiefly for bloom, but some of those that they eat, are not 
plums at all; they are not even anything like plums; some are the fruits of an ancient conifer, and represent perhaps a one-seeded cone. They are Ginkgo berries. They have persimmons which are a cultivated variety of a species akin to ours; but in the western world few people eat persimmons and none attempt their cultivation. The Japanese also has his own vegetables, his own grains, chiefly millet and rice, the use of which he shares with his cousin, the Chinaman; these brown men discovered both.

But the most wonderful triumph of the little brown man is not in his fruits, - he has on his "tight little island" small room for fruit - but in his flowers. No cultivated flowers of the world surpass those of Japan. Think of your chrysanthemum, the pearly white, the silken violet or purple, the perfect gold; think of your roses, the crimson rambler, the yellow climber, the weichurian creeper; think of your flowering plums that fruit not, your flowering cherries, that never bear, your flowering apples, without pomes, flowering quince - all these are the responses the plant world of Japan has made to the homely little gardeners that for centuries have moved in and out amid the forests and meadows of Nippon. Every dooryard in Japan, small though it be, is filled with shrubs that bloom; and when in April the blossoms come, the whole world as we know goes into ecstasies, celebrating out of doors the feast of flowers; not the formal easter of our western coldness, the advent of spring, the revival of life wherein we hardly dare forecast a life to be; but the feast of life that really blooms, wherein life not only returns again but returns in pur- 
ity, in gladness and beauty, to meet the best we have of appreciation, longing, hoping; better than the fruits we might consume - the fruits that perish in the using.

Nor shall we here forget the attainments of the men of this western world. For men they were, though Spaniard and Englishman alike destroyed them. To the primitive men of America the world owes the education of maize; and the wealth of Iowa and Illinois is at this moment the response of a simple plant to the gentle ministrations of the poor races who shaped the bowls and heaped the mounds from Canada to Peru. Columbus received mahiz from the poor brown people of San Salvador, small ears of Indian corn, ears no bigger than your fingers, but maize; and every school-boy knows how the Puritan found the New England races tilling the same wonderful plant. The great ears that now enrich our fields are the response to the careful tillage and selection of our Illinois farmers through a hundred years. Tschudi reports two varieties of maize taken from Peruvian tombs earlier than the tombs of any of the Incas, and Mr. Darwin found "on the coast of Peru heads of maize with eighteen species of recent sea-shell imbedded in a beach which had been raised at least eighty-five feet above the present level of the sea." Mr. Darwin gives this as evidence of far greater antiquity. Who can tell who first "began to pluck the ears of corn and to eat."

But there are a thousand other plants, whose origin is less obscure, whose response to the call of man has been no less significant. All our garden vegetables may be cited here: but one in particular may be taken to illus- 
trate the point. Along the shores of northern Europe, especially along the coasts of Helgoland, occurs a curious smooth, bluish, mustard-like plant, ealled by Linné Brassica oleracea. In cultivation the leaves of this plant grow so much faster than the internodes or stem that they do not have time to unroll, and we have cabbage. ${ }^{1}$ Now the number of varieties of cabbage is very great, from the little tough gnarly forms that our fathers knew, to the great purple spheroids offered by your modern gardeners and grocers. But, cabbage is only Brassica olerecea responding to man's preference for its monstrous leaves; not quite a foliage plant, perhaps, but practically that. It was for this our ancestors learned to prize it. It is significant that in German cabbage is called kraut; weeds are called unkraut; i. e., not kraut, indicating that for a time, at least, cabbage formed the only plant in Germany whose leaves might be used as an article of food. But in Brittany the farmers take the same plant and by continued plucking off of the leaves rear at length a lofty stem, ten to fourteen feet in height, which when dry may be used as a pole, a rafter, or for other constructional purpose. In Belgium the terminal bud is encouraged to unfold, by plucking the lower leaves until a form has been obtained which develops instead of a single terminal head a multitude of minor heads, one in the axil of each leaf in fact, and we have Brussels sprouts. Nor is this all. Certain types of the plant have been taught to bloom in an abnormal way. Men found the flowerstalks and flowers a pleasant succulent and lo, cauliflower is the result, formed from the same

1 From caput, head. 
original stock. Nay, farther; a variety with abnormally developed stem becomes kohl-rabi, and if the thickening be low down and form a subterranean stem or bulbous root we have a form of turnip.

The fact is, the whole vegetable garden is a marvelous response to man's solicitation in the world of herbaceous plants. Tomatoes have come up into their present almost universal popularity within the memory of men still living, and there are other plants whose response to human effort has been scarcely less astonishing. The navel orange is a curious illustration of the abandonment with which plants yield themselves to man's control. Here is a fruit which has absolutely given up its power of producing seed, its whole claim on the future, its perpetuity, at the bidding of the artful gardener. Botanists have long been familiar with what they denominate proliferation, the repetition of a flower beyond itself, of a flower which should otherwise terminate the stem, as the rose. Now the navel orange is, it seems, a case of proliferation; the first orange blossom did not check the twig, but the carpels of the first-formed flower carry up the axis to form a second smaller blossom and this makes in turn, in the top of the large perfected fruit, the second little orange whereat the world has wondered! All because luxurious man dislikes a fruit with seeds! The navel orange has entrusted its whole destiny to man: he may carry it along by budding; the tree makes no effort more to perpetuate itself. It has foregone the power of forming seeds.

But man's selective agency goes farther still; it reaches even the world of microscopic plants, and has nurtured 
and perpetuated forms which until recently the human eye had never seen! Here is yeast, for instance, a tiny plant that has the wondrous power of converting sugar into alcohol; men have been using this microscopic plant through thousands of years, using it and excluding other similar forms and yet they never saw nor even suspected the organism they handled. It is said that the ancient dynasties of Egypt understood the art of brewing. And so from generation to generation we have handed down our yeast; even to this day from hand to hand.

But there are stranger illustrations still. In the old European world in days gone by, as we know, there were scores of little principalities and states. Now nearly every little community, every Lilliputian commonwealth or kingdom had its own particular kind of cheese. There is Chilton cheese, and Cheddar cheese, and Cheshire cheese, in England; Edam cheese, Limburger cheese, Schweitzer cheese, Parmesan cheese, Rocquefort cheese, Neuchatel cheese, Guyére cheese, Bris cheese, and so on, and so on. Now all these differ decidedly one from the other, not in composition merely but especially in flavor; and we have lately learned that the particular flavor in every case is due to the particular microscopic plant that in the ripening of the product bears the upper hand. One tiny microbe presides over the soft delicacy of Neuchatel; another is dominant when the die is cast that summons forth the rich sweetness of the Dunlap or the Chilton; still another warms the Edam globe with its peculiar pungency, while the microscopic demons that bring to the famous Limburger its bouquet, far-reaching and far-famed, are, we may be certain, different still! 
That is, the bacteria and moulds of lactic fermentation have been cared for and watched by man and have responded to his fancy, lending him constantly the aroma he prefers. In this invisible microscopic garden unenlightened man has toiled for ages, moving as a gardener might move at night, among his plants, guided only by the sense of taste and smell. In fact, the more we study our inheritance from the dim and irrecoverable past, the higher rises our respect for those our far-away unknown progenitors. In a most noble sense we are all of us sons and daughters of Cincinnatus; nay of Adam, if you will; the man who was set in the earth as in a garden to keep it and to dress it. For all the civilization of the past two thousand years, it does not appear that we have discovered a single species, which our modern art has led to utility, to rival the rice and the wheat and the sweet-potato, and soy, and millet, and peaches, and cherries, and grapes and apples; all of which stood in human gardens from thirty to fifty centuries ago; all, responses to a cultivation so old that the primitive type must remain forever lost in prehistoric night. Such is the antiquity of horticulture and the lineage of Burbank, and his kind. ${ }^{1}$

But it is written that man shall not live by bread alone. Fortunately for us, men have found during all

1 Burbank accomplishes his results by crossing and selection. Crossing is certainly common in the natural world. In high antiquity we may suppose men were selectors only, taking advantage of such sports, mutations as doubtless constantly arose among the plants they sought. But later on, but before the Christian era, the more experienced people, now horticulturists, used precisely the same methods and upon the same plants which now lend fame to 
these years delight in plants for other reason than for the mere fact of food supply.

There is doubtless no element in human environment which brings to men generally so much delight as color. The savage races delight in it, as we all know, and with a piece of red calico you may buy in Africa the most precious possessions of a whole tribe. Nor less do civilized men enjoy the same sensation. How flat are all our photographic effects and how we long for some color-photographic process which shall enable us to capture the brilliant tints of the natural world. Nature gave us to behold blue skies, emerald seas, the rainbow's lovely form, the gilding that makes rich the evening sky, the splendor, the indescribable splendor that glorifies the Burbank and California, and with similar results, so far as the plants are concerned.

"Moreover, there are a kind of Abricots come from a forraine nation, and they be called thereupon Armeniaca, which alone for their smell also, are commendable. But there is a peculiar braverie and a shameless, which those Plums have by themselves that are grafted in Nut-tree stocks; they retaine the face and forme still of the mother grafte, but they get the tast of the stocke wherein they are set, as it were by way of adoption: of them both they carrie the name, and are ealled Nut-plums.

"It is not long since, that in the realme of Granado and Andalusia, they began to grafte plums upon apple-tree stocks, and those brought forth Plums named Apple-plums: as also others called Almond-plums, grafted upon Almond stocks; these have within their stone a kernell like an Almond: and verily there is not a fruit againe wherein is seene a wittier devise to conjoyne and represent in one and the same subject, two divers sorts." From Chapter XIII., The fifteenth Booke of Plinies Naturall Historie, translated by Philemon Holland, 1601, p. 437. Pliny died A. D. 79 ! 
gates of the morning, when the sun rises in his strength; we have all this apart from life and its ways. Now so far as terrestrial happiness is concerned, man's æsthetic sense seems to me almost his best endowment. But the æsthetic appreciation of color seems, however, secondary; the human eye has long been habituated to discover beauty in color before it will once consent to dwell with satisfaction upon the glory of the sinking sun. The confectioners tell us that children prefer candy with red stripes; notice, no man ever thought of decorating candy with green stripes; not for children. And so it happens that millions of people savage and civilized alike, see beauty in flowers and fruit, and butterflies and birds in brilliant colors all arrayed, who have never noticed a sunset or possibly even thought the rainbow worth looking at at all.

Our appreciation of beautiful things in this world may have been extremely utilitarian in the outset. The birds had already summoned forth the purple of the grape, the gold of the orange, the searlet of the cherry, before ever man had a thought of these things, before he ever existed at all; and man's first interest in these things as objects of color lay in the fact that the brilliant tints proclaimed his food. Hence it is that the baby likes red candy, while nobody has thought of making such things green - green never suggested food to anybody - save perchance to Nebuchadnezzar and such lovers of salad - but that was in the years of his misfortune. Nevertheless, we all know that we have long since passed that stage of human culture where beauty of form or color is associated in the mind, at least consciously, with the 
idea of advantage to be gained. Sometimes, however, you may yet hear a person exclaim, "That looks good enough to eat!" But children - mirabile dictu! — will still eat colored paints, and every sort of wild fruit that shines.

The sense of smell represents perhaps a much more primitive service. A man may see a great many oranges and not be moved to eat the fruit at all; but let him once smell it, and the case is different; even though, in all experience, the orange smells a great deal better than it tastes.

But, as has been said, as adults we are generally far past the mere utilitarian consideration of fruits. We may look upon an orange-tree in green and gold and rejoice in the magnificence of the spectacle, - even delight to see it spread in splendor over a thousand acres, with never a thought of hunger. And it is just at this point that the plant once more becomes our servant and stands ready to respond abundantly to these our late-acquired and high perceptions, the longings and aspirations of the sentient soul. And so we come to the admiration of fruit and flowers which we may not eat at all; we may even enjoy their odors and never think of food; breathe their fragrance with not a thought of banquets, until we come to the love of all these things in their purity, singly and in mass, and love them at length for their own sakes, and seek to have them near us; to place ourselves often under their spell and presence; to find in them a language suitable to our thought; to read into them meanings that in nature they never knew; to bind roses on the brow of beauty, orange-blossoms into the bridal wreath; and lilies even on the caskets of the dead, 
to speak to us of the freshness of some new, eternal morning.

It is when plants begin thus their highest and purest ministry that their response also becomes more and more refined, more and more part of the material of art. We have touched the wild rose in its simple beauty, with fine rose-red petals and a yellow disk of stamens, and it blushes in all the delicacy of the prairie queen, or masses its fire in the Jacqueminot or American Beauty, or lends itself to the production of that most subtle of delicate perfumes, the odor and sweetness of the tea-roses in all their manifold forms, or fairly glows in the blaze of the crimson velvet, or melts in the gold of the yellow Marechal Neill. There are more than four thousand varieties of roses.

The compositæ with fruitful center and rays that affect yellow, white or blue or red, we cultivate and behold! the daisy becomes a ball of orange - or white, or lilac, or violet, or all combined, and chrysanthemums simply fill the gardens of the world and make our social functions a spectacle of splendor. Pansies are listed in the thousands, and so are carnations, and dahlias and fuchsias, and all the rest. Nor is this all: we blend these things in park and garden to produce effects that make of our effort a picture, a blending of harmonious form and color, pleasing as some majestic masterpiece, whose conception and execution mark the summit of human creative skill. For this purpose not flowers alone respond but trees and shrubs in all their manifold wealth of form and habit, and especially in their docility, in the readiness with which, then properly treated, they lend themselves to our highest decorative purpose. 
Thus it appears that the higher response of the vegetable world comes only when man reaches the higher possibilities of his nature. So long as man demands food only, the plant furnishes forth bread; when man demands shelter, the plant is rich in shade; and now at last when the human spirit craves for beauty - the plant blazes in color and proclaims in every feature the lines of harmony and grace. It is a fact not wholly insignificant that the earliest page of human record puts man in a garden, - not in a tent, much less in ceiled house or palace, but in a garden, where vegetation should respond to every need. In 1625 Lord Verulam says in one of his famous essays:

"God Almighty first planted a garden and indeed it is the purest of human pleasures; it is the greatest refreshment to the spirit of man, without which buildings and palaces are but gross handyworks; and a man shall ever see that when the ages grow to civility and elegancy men come to build stately sooner than to garden finely as if gardening were the greater perfection."

To "build stately" is only the second stage then in human culture as concerns the use of the habitable world. First, food, then shelter, then beauty. First the wild delicious beauty of the Iowa wilderness; then the simple homes of wood set down amid the ranking corn or grouped in villages beside the streams; then the paved streets, the palaces in brick and stone: now the return to Nature. Wealth profiteth us not; the roar of commerce ceases to be music to our vexed and wearied ears. We are homesick children, all of us; we seek paradise. Now paradise means park. When to enlightened humanity 
has come, in the sating of our æsthetic nature, a success triumphant as is ours in the lower planes of human living, who shall then describe the beauty of this world! When all men seek beauty as the highest terrestrial ideal ; when a man's wealth is counted not in dollars but in the amount of ideal earth-culture that his hand controls, who shall then declare the splendor of this blooming fruitful planet!

What would the earth be if conformable only to the wisdom of our economies, to the law of wisest practical use; what then shall it be when to this perfection is superadded a condition responsive to our love of symmetry and beauty? Remember Nature knows beauty only - the beautiful:- the unbeautiful she forever covers and buries out of sight. Only untaught man interferes with her processes of harmony and purity and life; for the law of Nature is the law of eternal things, is the law of God. We shall never outrun her. Our parks, our gardens, our flowers, our fruits, our trees, shall never fail, nor shall our highest skill ever exhaust their patient, silent, activity and progress, their confident response.

Here now I might well end my story were it not that I am sure that even here there rises yet another argument in the minds of thoughtful people. There is yet one more response made by the green leafy world to the groping spirit of the sons of men, more delicate, more subtle yet, by far, by far. In all that has been spoken so far man himself is the aggressor; he suggests the response and the answer is as he desires. But the world was full of answers ere man dreamed at all, and to every nature- 
lover there are a thousand voices that come unbidden, half mystic if you will, but real withal in their effect upon the sentient soul, voices that touch the wanderer's every mood, that kindle anew his quiet joy in living, or by their gentler ministry soothe his perturbed spirit. The man who treads the great aisles of the towering forests on our western slopes passes under the spell of their mighty past and revels triumphant in the privilege of beholding. Giants a thousand years old rising above the prostrate trunks of other giants through hundreds of generations - all for him, and he possesses all their years and listens to the music brought pure and unalloyed from all the past. Or he stands upon the limitless meadow of the uninhabited grassy plain, and sees in the sunshine the wind-tossed waves chasing each other in light and shadow to the far horizon, and the wealth of future life is his, for shall not that flood sweep on and on, as he beholds it now, so long as the sun or the moon endures. Or sleepless, does he walk the desert on a starlit night amid sage brush, mesquit, covillea with its golden bloom, - every plant declares life's triumph and lifts him over every hardship and all the plagues and difficulties that anon did pester him and seemed so insurmountable. Or in some quiet grove at home do the whisperings of the leaves touch him with a sense of melody or of mystery? he listens spell-bound, charmed by the voice oracular that through countless generations spoke to his fathers the voice of God. His musings are unconscious memories. Here is the field for the poets, and no greatest man among them has failed to note it. Milton in Lycidas, Schiller in the Maid of Orleans, Shake- 
speare in A Winter's Tale and in his glorious sonnets, Wordsworth and Tennyson throughout, - all have discovered and declared this indefinable response of the world of leaf and bloom to the unuttered moods and passions of the human soul. Emerson, perhaps, in a line or two puts the case more simply, more boldly than any, saturated as he is with the poetry of the forest and of the book of books.

"When I'm stretched beneath the pines, And the evening star so holy shines, I laugh at the wit and pride of man, At the sophist schools and the learned clan, For what are they all, in their high conceit, When a man with God in a bush may meet?"

But all this lies outside the bounds of present science. Is it summer now? Once more the web of life is weaving: the robin once again sits perched upon his cherry tree; men and women go forth, go forth to labor, for robin as for man the shuttle flies unseen. Or is it autumn now? There is a haze above the river; a thinner sunlight smiles on wooded aisles, the poets and the children on the earth go once more up and down, gathering the tinted leaves, with meanings and responses that they at least can understand! 


\section{POINT LOBOS}

\section{The Plant's Response to Forces Cosmic in Their Origin}

Point Lobos is a small rocky headland, from the curving coast of California thrust out into the Pacific seas. Before it rise a score or more of petty islands, mostly mere rocks, covered at high tide, at low tide joined by ragged stony chains, mere wrecks, witnesses of ocean's all-devastating strength.

The parallel of north latitude $35^{\circ} 31^{\prime}$ meets the shoreline at the headland's western front, from San Francisco south, perhaps a hundred and twenty-five miles. To north of us is the Bay of Monterey for which our headland forms part of the southern enclosing wall, although Carmelo Bay indents the shore between. Both bays are well shut in by ridges of rock; in fact, we have here two of the lesser folds of the Coast Range of California mountains coming down to meet the sea; the one, the more eastern, Sierra de Salinas, gives us Point Pinos and Point Cypress farther north; the other, Sierra de Santa Lucia, terminates in the headland which affords the basis of our present study. East of Salinas at no considerable distance stretches the most conspicuous and the highest of these curious parallel folds, the Sierra del Monte Diabolo, to which reference will be made farther on. Between the two ranges first named, Salinas and 
Lucia, flows the little river El Carmelo, so named by the Spanish priests, a hundred and fifty years ago. Here was one of their mission churches, its ruins may still be seen, and the traveler, if the season favor, may yet pluck pears from trees of priestly planting just across the river. This is historic ground. El Carmelo is however a small short stream fed by springs and seeps, and Carmelo Bay is only the river's mouth, all choked and barred by shifting sands.

Point Lobos, then we say, is an out-thrust, an outthrust of a mountain, but that must not signify too much. In this locality the mountains are nowhere very high, three or four thousand feet at most, here by the shore not more than half so high, diminishing as they approach the ocean so that Point Lobos is simply a worn and battered spur, perhaps a hundred feet high where the wall goes sheer down to meet the breakers, perhaps two hundred feet high at the highest point, a hundred rods or more back from the cliff edge.

Now the promontory is crowned with trees, and the whole shore northward is wooded for several miles. East and south are the desert; westward is the sea, but on the westward rocks are acres of kelp, while hiding in every rocky niche and cranny a most beautiful live-forever finds lodging permanent, and decks the whole rocky face of these beetling cliffs with perennial bloom. At the margin of the cliff the trees are all distorted, gnarled, and twisted by perpetual struggle with the ocean wind. Many of the old warriors in this battle are already dead, but still stand as if immortal, their time-defying trunks and naked arms bleached white as the snows of winter. 
A lovely lace-like lichen hangs on all the trees both dead and living in filmy festoons tossing, while here and there, far within the shade, patches of another curious lichenaceous growth paint trunks and branches brown and gold.

Around Point Lobos, as the rule for points down by the sea, especially along the even coast of California, the winds play their incessant music. Sometimes they come roaring as if they had crossed the whole vast ocean in their onset simply to smite this one opposing rock; anon they simply sigh with sullen sough, or sing a requiem sad through leafless trees, that once, when living, answered with a shriller music. The sea, too, here has its moods. Sometimes the sea is glad; the sunshine glorifies its endless hues; its crystal waters lap the base of granite walls or stream through purling channels, or run in shallow waves along the snowy sands to chase the naked feet of happy children. Again the sea is sad; clouds hang low above its darkened waters, the sullen waves rise and sink amid the islands or now with falling tide make far retreat, disclosing all the slimy kelp and naked rocks that form the shingle of the world. Then the tide comes back and with it often comes the storm and the sea rages and roars; every wave gathers to the onset, sweeping the islands as if to eternal oblivion, climbs to the very summit of the granite cliff, and with its watery tongue licks down the overhanging crest, the turf, the flowers. Then the sun comes back with peace; the landscape reappears, the sluggish seals are lolling on the rounded rocks, and myriad sea-fowl whirl about the islands' undiminished heads. To landward loom the 
shades of dark-massed trees, and even the rocky walls are yet bedecked with storm-enduring flowers. Sometimes the densest kind of fog comes on as if heaven's whitest, softest, purest clouds came down to gently close the sense of sight and bid us use our ears. As in the song of the ancient mariner, "we cannot choose but hear." We hear the barking of the seals, the scream of the sea-birds, jostling each other on that island's top; the murmur of the softened waves as now they rush in streams through hidden caverns of the rock beneath us, nor less the dripping of the upper waters falling in gentle raindrops from the swaying lichens over and about our heads or even trickling in tiny rivulets adown the trees. Point Lobos is a charming place, the sea, the mountains, and the woods; what more can you seek? Here is the most lovely bit of ocean scenery that some Americans have ever known, or, at least, have had opportunity to admire.

But these are usual charms: these possibly may be found elsewhere. In the turmoil of this mundane life few of us have wide experience. Each knows his own, unknown to others, and for each his own is good. But Lobos has some special and for the student some peculiar graces. Here is geology. The foundations of the earth are uncovered; the very core of the mountains is laid bare. Upon these ancient bases primeval all sorts of rocks have been laid down. Professor Lawson of the University of California, who has studied the geology of the region for us, calls peculiar even the granite here exposed; he also names it pre-cretaceous, which means 
nothing if not that the earliest deposits on it indicate the shore-line or bottom of the cretaceous seas. However this may be, evidence of unusual geologic change is everywhere within the shortest distance. Eocene, miocene, in great thickness and many distinct strata were spread abroad, all before ever these mountains were formed at all. Then comes the folding, the mountainmaking, and the subsequent erosion and then the pliocene laid against the face of all these hills, probably to the height of eight hundred feet. On the southern slope of the Point, a most striking formation, probably eocene, lies immediately on the granite; there it is, anybody can see it; a conglomerate, an ancient sea-bottom, fossilized, full of boulders worn, and pebbles and sand all cemented together, capping the granite. You have seen the same thing on the top of the Alps, on the Rigi, for instance; but wherever seen the situation is one of the most marvelous and tells of the age of this world and of its changes as can nothing else. This old sea-bottom is crowned now with flowers and trees but all returning rapidly, lapsing into the maw of that restless, insatiate sea. There it goes, even while you watch! That big wave which you but just escaped has broken off the very coast on which you stood and is even now rolling it back in its retreat far down the shingly bottom. Those who follow us a hundred years from now will see another shore-line. Ours will have become part and parcel of the ocean floor. And yet, they say, the coast is rising. Every once in a while Dame Nature shifts a little these outer fringes of her mantle and all California goes trembling 
with an earthquake. ${ }^{1}$ Eight hundred feet the coast has risen here since these newest gifts of ocean were piled along the shore, only to be again resumed piecemeal as we have seen. Meantime the steady waters of erosion, the rains and the snows - snows, too, as we shall see have cut out the valley of the Carmel River; not so long ago, if one may judge by those steep slopes and highbuilt terraces that here hem the river in.

But all that has been described is tertiary; there still remains the time of this erosion, the quaternary between these old deposits and the present. The famous icesheets of which to-day we hear so much, affected California too. The entire Sierra range far south as latitude $36^{\circ} 32^{\prime}$, the line of Mount Whitney, was one vast mer de glace. Mount Whitney is scarred on every side with the traces of vanished glaciers, glaciers that once filled up the valleys of Kern's and Owen's rivers and rested away out in the basin of what is now Tulare Lake with its surrounding quags and swamps. While all this was going on we may be sure that our ranges nearer the sea were not neglected. They too must have been crowned with snow, which while possibly not sufficient to form glaciers did nevertheless furnish constant and voluminous streams that cut out the channels of these sea-side rivers. It seems incredible that the sun-baked fields of California were once the scene of unceasing winter, but all evidence seems to prove just that very thing. No glaciers ever touched Point Lobos, but perennial snow no doubt cov-

1 This was written before the now famous disturbance of April, 1906. 
ered all the ranges immediately to the east the whole series of the mountains of Diabolo.

There is no time to-night to tell of the zoölogy of this peculiar region. Suffice to say that this, too, would, if properly presented, form a most interesting chapter. These rocks fairly swarm with a multitude of animal forms, some of the most beautiful things on which man ever gazed in all this beautiful world. Sea-urchins in royal purple dressed; sea-anemones finer and fairer if possible, than the flowers that deck the overhanging land; scuttling crabs of every possible hue: haliotis so abundant that the industrious Japanese has here set up an abalone fishing station and sends off continually tons of these beautiful shells to every part of the world. The fauna of the place deserves the enthusiasm of the zoölogist.

But now, with all this varied background, let us turn our attention to the world of plants, especially to the trees: these offer the botanist's problem of the locality, and it is their response to these cosmic changes, these shiftings to and fro of shore and mountain, that make Point Lobos famous. The flora of Point Lobos is not only peculiar in California, the land of peculiar things and peculiar people (sotto voce), but it is peculiar on the planet, unrivalled in the world. Here is a curious mixture; on the one hand we have the flora of the desert, Artemisia, Chenopodium, Eriogonum, and all those semi-shrubby things that dot the desert all the way across the continent. On the other hand, we have a mountain flora and this unique; we have pine and live-oak and cypress for trees, with typical mountain ferns, among which the famous 
gold and silver ferns are not without their representatives. The oak is Quercus chrysolepis, a species rather common in central California, but nowhere else in the world. The pine is Pinus radiata, the Monterey pine, about the Bay of Monterey, nowhere else in the world. The cypress - there are two of them; one is Cupressus goveniana, a small shrub-like tree on sun-burnt slopes, found here in a single colony and also in similar position at Cape Mendocino; the other, here discussed, is Cupressus, macrocarpa, the Monterey cypress, occupying an area two or three miles long from Cypress Point to Point Lobos, and not exceeding two hundred yards in width, and nowhere else in all the world! Even the little liveforever is unique, limited to this immediate coast-line. About these three plants our present argument may turn. It is needless to say that a situation like this possesses peculiar interest; it is an interrogation point. It calls loudly for explanation. Of course, not so very long ago no one had thought of offering any explanation. We had a strange way of looking at things in those elder days. When a boy I was shown a most curious plant, a shrub found by our northern streams, formerly not rare, the leatherwood. I was informed that this shrub was unique, the only thing of its sort on this side of the world; that it was planted here by the Creator to meet the wants of the red man who was wont to use its tough pliable fibrous bark in ald his simple industries. I by no means dispute that older explanation: it were perhaps hard to demonstrate its lack of truth. It has in its support the fact indubitable that the bark was used as described; but nevertheless, I do not believe that just 
that explanation would ever be offered now. On the other hand we should simply say, having less immediate respect to reasons teleologic, where is the rest of it? This species seems to be monotypic, here wholly alone; where are its congeners? And so in the present problem, our first inquiry is - How in the world did this happen? Where are the rest of the cypresses? where are the kin of this particular pine?

The cypresses of North America are seven: one known as the white cedar occurs along the Atlantic coast and is associated with the bald cypress, a relative but not of the same genus; three are Mexican and two belong to Oregon and Washington, while one is confined to the peninsula of Lower California. All are Pacific Coast species but one. On the other side of the ocean the distribution is equally peculiar. There is no cypress in western Europe; two or three are in China or Thibet, one of which is now found as far west as Constantinople, planted everywhere over graves: curious fact; not without suggestion, but not to be here discussed. It seems then that the cypresses tend to follow the shore-lines of the great continents. They are few; they are northern; they do not exist south of the equator and in fact form two groups, separated by the whole diameter of the globe. This of course would only deepen the mystery that surrounds our lone California species, were it not for some other facts the first of which began to come to light about fifty years ago.

Just about one hundred years ago, in 1807, in fact, a man named John Franklin having won distinction at the famous battle of Trafalgar, was put in command of an 
English ship to survey the northern coast of Australia. On that ship, as it happened, fared forth a remarkable student of nature. He was a botanist, bearing the simple name of Robert Brown, one of the greatest naturalists, I believe the greatest botanist, that ever lived. Be that as it may, Brown so impressed his captain that the latter resolved then and there to devote his life to scientific investigation. We all know the rest of that thrilling story; how under Sir John Franklin and those who followed him, expedition after expedition visited the extreme north under an inspiration that has never flagged; unabated to this very day. Nor have these expeditions ever lost the primal purpose of John Franklin. Every vessel that has returned, from the days of the Erebus until now, ${ }^{1}$ has brought back new facts, new truth, and new problems for thinking men. Early in the fifties a vessel returning from Grinnell-Land unloaded a cargo of fossil leaves. Further research brought similar material from the coast of Greenland and from Spitzbergen. These by good hap were sent to Switzerland, to a busy minister there who had been recently picking up similar objects, then all unstudied, at different places in the Alps! To the astonishment of the world Heer reported from Grinnell-Land and from Greenland, all sorts of flowering plants of types familiar, but now found only in temperate or semi-tropical lands. There were poplars and walnuts and hazels, nor less magnolias and laurels and figs. Heer had found something more than fossil leaves; he had so to speak, discovered a fossil climate, and the key to the distribution of the flora of all the

1 Dr. Cook had not yet returned when this was written. 
northern world was in his hands. Among the finds of this arctic region, almost needless now to say, the leaves and cones of cypress are not wanting. You may see some of them, if you please, yonder in Lausanne, in the now forever silent workshop of Pastor Heer. The cypress was abundant in the tertiary all the way around the arctic world. Point Lobos as we have seen was a sea-bottom in those days, but before the tertiary had passed away, the whole coast range of mountains had risen from the ocean, Point Lobos of course with the rest, all un-named, unvisited of men, a headland standing far out to sea.

Some time near the close of the tertiary, these arctic forests of Heer began a marvelous migration. The climate of the polar regions began to change for reasons, causes, who may tell? and as the isotherm came south the several species followed, each on its own meridian. Great Lakes in those times occupied the center of the continent or perhaps even then, these lakes were drained or draining, inducing the same desert conditions that now mark all the central plains. Of cypress one only species, or stock, went down the eastern coast as we have seen, driven farther and farther by the oncoming age of ice, others went down the western coast, far down into Mexico, even; among the rest our Monterey species driven coastward too ; caught at length, strangely enough, between el Monte Diabolo and the deep sea, and there it is to this day, a bit of jetsam, from the Mer de Glace that one time made all central California like the present arctic zone. With the cypress went south the pines too, probably, and the sequoias, and all the rest. Some 
of these perhaps never passed the limits of southern California; some passed on into the cul de sac known as lower California, and have never gotten out, one pine, at least, and one cypress. The cypresses seem always to have lead the van for they are nearly all found to-day on the very outskirts of forest vegetation, whatever the region may be. One Mexican species is in Oaxaca, the very southernmost Mexican state, on the Pacific sea again, in that low latitude, $15^{\circ}$ north.

But as already noted, the ice-king's reign in California was not forever. The ice is nearly all gone now, has been for centuries, save that here and there a diminished glacier still lingers in some shaded trough on the peaks of the Sierras, and still forms the icy fountain of some fair California stream. With the retreat of the ice the plants moved back again, or at least attempted so to do. The march, of course, is now in reverse order; larches and spruces and pines now lead the procession while sequoias and cypresses are left the last to bring up the rear. They are marching now; by noting their present position you may see the progress of this stately journey. The gentle sunlight beats their music on the mountain-spires, and the earth herself keeps time for them, nodding, nodding, in nutation and precession. ${ }^{1}$

But, as in returns of any sort, the original order is never quite preserved, so here, the sequoias or "big trees" are following close behind the pines pushing north and west; one species has slipped in before our cypress and in fact effectually shuts it off from the

1 See in this connection Our National Parks, John Muir, pp. 335 et seq. 
entire northern California coast, a region the species might otherwise have occupied, since it does grow further north when planted. The superseding species of redwood starts in at, say at Punta del Sur, fifty miles or so down the coast, and runs northwest, just inland from the species we are studying, and only a few miles away, on Portland Creek, then on to Santa Cruz, just across Monterey Bay and finally the coast range, not without interruption, but all the way to Mendocino and further. The only other sequoia took, on the return, the Mount Whitney route, fills the Valley of the Yosemite and King's River cañons and has gotten north as far as the Calaveras. Meantime two species of cypress seem to have outstripped the sequoias, and are found along the coast beyond Mendocino, one species even in British America sparsely but indiscriminately mingled with other coniferous trees!

But our Monterey cypress and our Monterey pine are stranded, like other refugees of whom history tells a not infrequent story; they became separate from their brethren in the time of stress, and have remained an isolated colony ever since. It seems that the retreat of the glaciers in middle California was in some way accompanied or associated with diminished rainfall, or snowfall, and the departure of the snows left Mount Diabolo a desert on its western side, on both sides in fact. Up the valley close behind the retreating forests came the flora of the desert, waiting to entrap and utterly supplant all stragglers, as wolves were wont to bring down the straying deer. Our cypress trees are doomed; they have been left behind in the shifting of the ages 
and left forever. Only the hand of intelligent man can save them now. As just remarked, they will grow, where planted as far north as the Columbia River, and will probably be thus perpetuated in cultivation. The associated pine, though now occupying a somewhat wider freehold, is after all not so fortunate. Of little value for lumber, and less tractable in cultivation, it has small assistance from our present system of economy. For years the Chinaman has been busy hewing the Monterey pine away to feed the furnaces of the Hotel del Monte, as well as the insatiate if more modest heaters of a thousand houses. Besides this, chicken-farming is the fashionable industry of the region and to afford room for such gentle activities, the pines are widely cleared away. Upon our criminally careless methods of cutting, the usual disasters have of course ensued. Great fires, started in refuse left by the Mongolian choppers, some years since burned over several thousand acres. But for this tree, the site of Hotel del Monte and the village of Pacific Grove would see but plains of wind-swept sand. The live-oak, as it appears, cannot do the work alone.

The third plant mentioned, the live-forever, true to its name, seems destined to immortality. It has found its home in the niches of the granite, keeping pace with its retreat before the advancing ocean. The race in this world is sometimes not to the mighty.

Hoc fabula docet;

1. No fact in the natural world is insignificant. A few old pine trees on a rock may have a scientific interest far transcending that of some wide-spread forest.

2. No fact in this world is isolated. The destiny of 
the Monterey cypress, its whole history, has been bound up with the history of every part of the world, nay probably of the solar system entire. The changing scenes of geologic ages pass before us, and the very latest field of effort and inquiry, the pleistocene, with its record of alternating climate, even our latest knowledge, touches also Monterey.

3. How very small is still the scope of human knowledge! We find here and there a fact, here and there a bed of leaves. Upon these we build, and by imagination lightly span vast stretches of the unknown. The cypress was once in Greenland, it is now in California. But where lay the causes of the change in climate, the motive of this migration, or what were the incidents of the journey, no single ascertained fact may yet certainly declare.

Here then we are able to trace the probable history of at least one type of existing conifer and learn the later chapters in its history - not the earlier - who knows what these may have been or how the cypress reached the arctic pole? Yet from what we now behold we are sure those earlier chapters once were plain: Only of this we may be sure: were the whole record once before us, we should find our cypress a stranger even at the pole, a passing transient whose ancestors had, in the ages gone before, carboniferous devonian, obedient to continual summons, journeyed up and down the shaping continents of the world, responsive to all the perturbations that have moulded the planet itself, persistent, perpetual, relentless as the lapse of years. 


\section{THE BOTANY OF SHAKESPEARE}

The universality of Shakespeare is the common remark of crities. Other great men have been versatile; Shakespeare alone is universal. He alone of all great men seems to have been able to follow his own advice, "to hold as 'twere the mirror up to nature." On the clear surface of his thought, as on a deep glacial lake, the whole shore lies reflected - not alone the clouds, the sky, the woods, the rocks, the mountain path by which the shepherd strolls, not alone the broad highway by which may march the king in splendor, the peasant with his wain, but even the humbler objects by the still water's edge, the trodden grass, the fluttering sedge, the broken reed, the tiniest flower, all things, all nature in action or repose finds counterpart within the glassy depths.

Hence it is that no man, at least no English-speaking man, reads Shakespeare wrong. Everybody understands him. Here is a sort of Anglo-Saxon bible in which, so far as the world goes, every soul finds himself, with all his hopes, his doubts, his whims, depicted. We are therefore not surprised that everybody claims a share in Shakespeare; rather claims the poet as his own. The Protestant is sure that Shakespeare despised the hierarchy; the Catholic is quite as certain that he loved the Church. There exists an essay to prove him a Presbyterian; another to show that the great dramatist was a 
Universalist. A volume has been written to prove the man a soldier; another that he was a lawyer, a printer, a fisherman, a freemason, and here are five or six articles to show that Shakespeare was a gardener. ${ }^{1}$

All this simply means that the poet had a marvelous faculty for close observing; that his vision was accurate, his instinct wonderfully true. It may be therefore worth our while to study for a little this remarkable man from the standpoint of the naturalist, to see how he who so vividly paints a passion can paint a flower; how the man who limns a character, till beyond the photograph it starts to actuality, will catch the essential features of some natural truth.

We shall nowhere lack for material. Shakespeare has abundant use for flowers and trees. Other poets before his day had mentioned vegetable forms indeed, mentioned them in plenty and observed some of them with great precision. Chaucer and Spenser, for instance, both use the world of plants wherewith to adorn their songs and stories; but it requires only the briefest examination to show that these earlier writers use their material in an entirely different way; on purpose, so to speak; that is, the flower, plant, or tree is introduced purely as a matter

1 In preparation of this article, the author has consulted chiefly the following: John Gerarde, The Herball or General Historie of Plaints, 1597; Shakespeare, Edward Dowden, 1872; William Shakespeare, Works, Globe edition, 1867; Natural History of Shakespeare, Bessie Mayou, 1877; Shakespeare's England, William Winter, 1894; The Plant-lore and Garden-craft of Shakespeare, Rev. Canon, H. F. Ellacombe, 1896; The Gardener's Chronicle; sundry pamphlets, and shorter articles; Shakespeare's Works, annotated edition, Sir Sidney Lee; Shakespeare Once More, James R. Lowell, 1868. 
of form, for the time as the main topic of discussion, to show what the poet has heard or read.

Take, for instance, Chaucer's picture of an English forest and his quest there for the nightingale. The nightingale is the proper bird for the poet. The poets had often told each other so. Chaucer had read what his predecessors had to say, and accordingly, on a certain morning, as if to meet a personage of distinction, he arrays himself appropriately and sallies forth a little way from London to hear, if fortune favor, the poetic bird of languor. This was a most creditable thing to do; Chaucer was scientific so far; he wished to see and hear for himself. Literary men in all ages are wont to worship traditional nightingales; not so Chaucer. But hear him :

"Up I rose three hourés after twelfe About the springing of the gladsome day, And on I put my gear and mine array, And to a pleasant grove I 'gan to pass Long ere the brighté sun uprisen was;

“'In which were oakés great, straight as a line, Under which the grass so fresh of hue Was newly sprung; and an eight foot or nine Every tree well from his fellow grew, With branches broad laden with leavés new, That sprungen out against the sunné sheen, Some very red, and some a glad light green,

"Which (as me thought) was a right pleasant sight;

And eke the birdée songés for to hear Would have rejoicéd any earthly wight;

And I, that could not yet in no mannere Hearen the nightingale of all the year, 
Full busily heark'ned with heart and ear,

If I her voice perceive could anywhere."

- The Flower and Leaf

Here you will note we have a formal description of the oak forest - effected by enumerating particulars. You go out to see the forest and you see it, the spaces between the trees and all.

Take another bit of Chaucer by way of contrast: this, as discussion of a flower, is from the Prologue to the Legend of Good Women:

"When comen is the May, Then in my bed there daweth me no day That I n'am up and walking in the mead, To see this flower against the sunné spread, When it upriseth early in the morrow;

That blissful sight softeneth all my sorrow;

So glad am I, when that I have presence

Of it, to doen it all reverence,

As she that is of all flow'rs the flow'r."

"And down on knees anon right I me set, And as I could this pleasant flower I grette, Kneeling always till it unclosed was Upon the small and soft and sweté gras.'

This is surely a bit of pleasant affectation, not unlike the raptures of the Chicago lady who on the Alps worships the edelweiss, the form and real meaning of the flower alike to her unknown.

It is needless to say, Shakespeare never does anything like this. You are carried naturally forward on the tide of his story and see the flowers as you pass by. They are about us all the time, and his dramatis personce may pick them, use them as they will. He never thinks 
of describing for the purpose of our recognition, as does Chaucer, or of giving us all at once a list of trees as does Spenser; and yet he knew all the trees that Spenser knew; but, in our journey, we meet the trees, trees of every sort, and they serve a temporary purpose in the unfolding plot as in the spreading landscape. They overarch the king, they catch the first glances of the morning light, they wag their tall tops against the sky, they stand bare and dead on some forgotten shore of Timon's dismal exile; but in every case they stand just where they belong; they have always their appropriate setting. Furthermore, they always come to the relief of the principal action. They are like the background of the well-appointed stage; they relieve what might otherwise prove harsh or dissonant. This comes out more than once. Some of Shakespeare's most beautiful touches, so far as blossoms are concerned, come in the very climax of the play's most sombre or pathetic movement. We walk with Horatio "in the dead vast and middle of the night" when suddenly the darkness parts and our eyes rest upon whole banks of bloom all glinting in the brilliance of some sudden beam. Ophelia sings and dies amid the flowers.

The extreme naturalness of Shakespeare's touch is due, in part at least, to his boyhood familiarity with rural sights and sounds. England in Shakespeare's day as now was a land of bloom, and the poet spoke of violets and primroses as naturally as his Lord spoke of lilies and for the same reason; those were the flowers he saw, had always known; they formed part of the furnishing of his mind. But Shakespeare does more than mention 
the plants that share in the splendor of his pageantry; he is not content at all with the flashes of color, the breathings of odor; he generally gives us a single detail that flashes the individual plant unmistakably upon our sight. In his quick description he shows an exactitude, a discriminating perception that, had it been turned to Nature's problems seriously at all, must at once have transformed the science of his age. But Shakespeare was not a man of science; he was a poet. In his views of nature he resembles the great poets of the world, notably Lucretius; and like Lucretius he not infrequently outruns the science of his time, uses his imagination, divining things invisible. Moreover, consistent with the necessities of action, Shakespeare's plants are living things; they form a garden, not an herbarium. They stand before us in multitudes so that it is difficult for the present purpose to know what to select. We shall have to be satisfied with a few specimen forms brought out in quotation no more extensive than seems necessary to the argument. Of course, there are many plants today discussed of which Shakespeare never heard. He does not speak of many sorts of fungi, of slime moulds, microbes; he knew nothing about these. The microscope had hardly been invented, and the unseen world was as yet largely personified. And yet Shakespeare has not failed to note the visible signs of some of our microscopic forms.

Critics have wasted their time and the patience of mankind in an effort to identify hebona, the "leperous distilment" poured into the porches of the royal ear. Almost profitless are such discussions. Yet we may 
note that we have here to do with an effect; the means of producing it need not be too closely questioned. Before the rush of action, the weird setting, the voice of an apparition, the excited audience cares not what the mysterious vial may contain - ebony, henbane, yew, or whether it were entirely empty. What is called for is a speedy and mysterious taking off. Had the scene been laid in Italy, the effect had been reached by the fateful prick of a jeweled pin, some ring upon a Borgian finger whose pressure was the paralysis of death. But the king died of no such curari. Note the symptoms:

"The leperous distilment; whose effect

Holds such enmity with blood of man

That swift as quicksilver it courses through

The natural gates and alleys of the body, And with a sudden vigour it doth posset And curd, like eager droppings into milk, The thin and wholesome blood; so did it mine; And a most instant tetter barked about, Most lazar-like, with vile and loathsome crust, All my smooth body.", - Hamlet, i: v, 64-73.

These are the symptoms of blood-poisoning, vividly portrayed; of some contagion, communicable by infection. In foul old London, Shakespeare had doubtless seen endemic, zymotic diseases of every description, and drew his picture from the life. Royal blood is notoriously unsound, royal habit leaves the porches of royal ears especially exposed. On our supposition the vial need not have contained very much, not even "ebony." The dramatist had plenty of mystery ready to his hand, and the "hebona" is perhaps intentionally ambiguous. 
Bacterial diseases were of old called plagues; they fell from heaven. Listen to King Lear:

"Now, all the plagues that in the pendulous air

Hang fated 0 'er men's faults, light on my daughters!"

- Lear, iii: iv, 68.

or Caliban:

"All the infections that the sun sucks up

From bogs, fens, flats, on Prosper fall and make him

By inch-meal a disease!" $\quad-$ Tempest, ii: ii, 1.

or Timon:

"Be as a planetary plague, when Jove

Will o'er some high-voiced city hang his poison

In the sick air." - Timon, iv: iii, 108.

Or they were attributed, as already intimated, to unseen personal agencies:

"This is the foul fiend Flibbertigibbet: he begins at curfew, and walks till the first cock; he gives the web and the pin, squints the eye, and makes the hare-lip; mildews the white wheat, and hurts the poor creature of earth." - Lear, iii: iv, 120.

I quote this latter rather also to show the accuracy and compass of Shakespeare's vision. How many people, not farmers, have seen wheat whitened by the blight! And that is exactly the description, white not "to the harvest," but whiter still to sterility and death.

But leaving aside all microscopic forms which may or may not be incidentally touched upon everywhere, we may turn our attention next to eryptogamic plants which are positively defined. The sudden springing of mushrooms, for instance, especially at night, so unreal and yet 
withal so realistic, made their creation a suitable trick for Prospero:

$$
\text { "You demi-puppets that }
$$

By moonshine do the green sour ringlets make, Whereof the ewe not bites, and you whose pastime

Is to make midnight mushrooms, that rejoice

To hear the solemn curfew.", - Tempest, iv: $\mathbf{v}, 36$.

The green sour ringlets on the fields "whereof the ewe not bites" are fairy rings. The same thing appears in the speech of Dame Quickly:

"And nightly, meadow-fairies, look you sing,

Like to the Garter's compass, in a ring;

The expressure that it bears, green let it be,

More fertile-fresh than all the field to see."

-Merry Wives, v: v, 69.

Fungi, toadstools, mushrooms, and so forth, are fructifications only; the vegetative part of the plants permeates the soil, feeds on its organic matter, and spreads almost equally, we may assume, in all directions from the point of starting. When now this vegetative growth has accumulated energy to form fruit, the sporocarps, or mushrooms, rise all around at the limits of activity: hence, in a circle.

The fungi cut small figure in Shakespeare - i.e., considering their numbers and almost omnipresence. But we must remember that they were at that time studied by few, their significance and interest little suspected. They formed part of the realm of the world unseen; they came and went at the instance of powers unknown, mostly personified, imaginary, a misty population, the thought of which kept for long ages the childhood of our race in 
terror. Shakespeare saw the forms of unstudied plants, everything visible to the naked eye, and really omitted very little. He speaks of mosses - the lichens were included with them - chiefly as indicative of age in the object on which they rest:

"Under an oak, whose boughs were mossed with age

And high top bald with dry antiquity."

-As You Like It, iv: iii, 105.

or again :

". . . will these mossed trees

That have outlived the eagle page thy heels, And skip where thou point'st out?'"

-Timon, iv: iii, 223.

Then again he simply touches them, but in such a way as to reveal his full appreciation of their beauty, as in Cymbeline, iv, ii. For the decoration of Imogen's grave the ruddock would bring flowers -

"c. . . bring thee all this;

Yea, and furr'd moss besides, when flowers are none,

To winter-ground thy corse." -Cymbeline, iv: ii, 224.

The "furred moss" to "winter-ground thy corse" is exquisite.

Ferns, though so much larger, so handsome, and in our day so all-attractive, failed generally to impress our fathers.

Butler, writing in 1670, has this to say:

"They spring like fern, that infant weed,

Equivocally without a seed, And have no possible foundation But merely in th' imagination." 
Now, as far as Shakespeare was concerned, ferns answered his purpose without seed just as well as with such visible means of perpetuity. His only reference is in the lines where Gadshill says :

"We have the receipt of fern-seed, we walk invisible";

and Chamberlain replies :

"Nay, by my faith, I think you are more belonging to the Night than to fern-seed for your walking invisible.'

- I Henry IV, ii : i, 95.

In this connection Canon Ellacombe suggests the doctrine of signatures. The God of Nature had written for us his human children prescriptions all over the leafy world. The remedy indicated by its form its own application. Thus a heart-shaped leaf was good medicine for cardiac troubles, a lung-like leaf was good for consumption, a lungwort in fact, and so a liverwort, a spleenwort, and the like. Gerarde, and, in fact, all the old medical writers throughout the centuries, are full of this. Now, what more natural than that a plant which could thus perpetuate itself age after age by means invisible should be able to confer the much-sought gift of invisibility, the power to disappear and reappear at pleasure? Many people so believed. Shakespeare appears to have been skeptical.

Turn we now to the flowering plants; the amount of material at our disposal, as already indicated, is immense. Shakespeare was evidently a great lover of flowers simply as such. His pages from first to last are ornate with color, almost redolent of roses, lilies, eglantine, 
with every conceivable metaphor and trophe - "the bud of love," the "nettle of danger," "the flower of safety." Their lovely shapes are ever before him; he is spellbound with their beauty. England itself is a "sea-walled garden." Grammatical forms may vanish, if only the flower may live :

"Hark, hark! the lark at heaven's gate sings,

And Phœbus 'gins arise,

His steeds to water at those springs

On chaliced flowers that lies."

-Cymbeline, ii: iii, 21.

We need the music of rhyme, and so the image of the morning flowers, the fiery steeds that drink them dry, shall fascinate us that we forget the grammar. It will not do to say lie; the word must rhyme with arise, and further on with eyes;

"And winking Mary-buds begin

To ope their golden eyes:

With everything that pretty is, My lady sweet, arise."

For the Queen of the Fairies the poet spreads this sort of a couch:

"I know a bank where the wild thyme blows, Where oxlips and the nodding violet grows, Quite over-canopied with luscious woodbine, With sweet musk-roses and with eglantine; There sleeps Titania sometime of the night, Lulled in these flowers with dances and delight," etc. - A Midsummer-Night's Dream, ii: i, 249.

Such cases reveal the impress, the healthy, happy im- 
press which Nature could exercise on this the foremost man of all the world, the harmony between Nature and Nature's child. All the plants in the last quotation are wild flowers, except the musk-roses, and these are so common in England as to be almost wild. The eglantine was the sweetbrier, said to be wild in all the southern part of the island and popular in the literature of all recorded centuries. Canon Ellacombe here cites Gerarde describing as follows: "The leaves are glittering, of beautiful green color, of smell most pleasant. . . The fruit when it is ripe maketh most pleasant meats, and banqueting dishes, as tarts and such like, the making whereof I commit to the cunning cook, and teeth to eat them in the rich man's mouth."

The sweetness of the leaf of the eglantine is referred to by Shakespeare in another passage which I venture to quote now for another purpose, to show the accuracy of his description as applied to simple flowers. The lines bre from the scene quoted before. Arviragus and Guiderius would bury the swooning Imogen. They think her dead:

"I'll sweeten thy sad grave: thou shalt not lack

The flower that's like thy face, pale primrose; nor

The azured harebell, like thy veins; no, nor

The leaf of eglantine, whom not to slander,

Out-sweetened not thy breath.", -Cymbeline, iv: ii, 220.

Primroses when pale are the palest of all withering plants. The flowers change color with maturity, especially after fertilization. The paleness of the primrose is the pallor of decay. But the azure harebell - behold it 
waving on its slender stipe beneath the shade of some great rock - who can look into its delicate cerulean cup again and not bethink him of the blue-veined eyelid sleep that falls upon our human flowers!

The cowslip is another common English flower painted by Shakespeare to perfection. The meadows about old Stratford church are yet to this day full of representatives of this curious species. The cowslip is a primrose but remarkable for orange-tinted spots decking the bases of the petals. You may not see these markings unless you pick the flower to pieces. Then when you hold the petal up to the light the spot shines ruby red. Now Shakespeare says, speaking of Queen Mab:

"The cowslips tall her pensioners be;

In their gold coats spots you see;

These be rubies, fairy favors,

In those freckles live their savors;

I must go seek some dew-drops here,

And hang a pearl in every cowslip's ear."

-A Midsummer-Night's Dream, ii: i, 10.

To understand all this we must remember that Queen Elizabeth was in the habit of conferring upon her favorites certain monopolies of one sort or another. Men so favored grew very rich and were of course the objects of envy on the part of their neighbors. They were called pensioners and, as the nouveaux riches generally, seem to have been fond of display.

The cowslips then were the pensioners of the fairy queen. But imagine the poet holding up the petals of this simple flower, holding them to the light, he could not 
have used them unless he had so done, and then at last, far from envying the creatures of the royal bounty, he seems the rather to smile at all their pomp, as if in holding up the little flower he said again - "Even Solomon in all his glory was not arrayed like one of these."

The same accuracy of detail is evinced in many other places. Take, for instance, Shakespeare's description of the violet all the way through. It moves him chiefly by its odor:

"To gild refined gold, to paint the lily, To throw a perfume on the violet, To smooth the ice, to add another hue Unto the rainbow, or with taper-light To seek the beauteous eye of heaven to garnish, Is wasteful and ridiculous excess."

-King John, iv: ii, 11.

Nevertheless, we have violets dim, and violets blue, and purple violets, and more particularly "blue-veined" violets, as if the poet looked with a lens into the very throat of the flower which Frenchmen call "a thought." "And there is pansies - that's for thoughts."

His description of the elm is equally exact:

"So doth the woodbine the sweet honeysuckle Gently entwist; the female ivy so Enrings the barky fingers of the elm." - A Midsummer-Night's Dream, iv: i, 47.

There is nothing better than that, as you may prove by examining the twigs of even some of our American species; the cork elm, for instance. The hawthorn, the cedar, and the pine and the oak especially, are most nat- 
urally treated. These are Shakespeare's favorite trees. The cedar of Shakespeare is the cedar of Lebanon, commonly planted throughout Europe since the time of the crusades. Shakespeare had probably seen specimens in England. He uses it as the type of all that is great and fine. One author thinks he copies Ezekiel, chapter xxxi.

The pine was beside him all the while. He knew the secret of the pine knot, and well described it:

\section{". . cheeks and disasters}

Grow in the veins of actions highest reared, As knots, by the conflux of meeting sap, Deflect the sound pine and divert his grain Tortive and errant from his course of growth."

-Troilus and Cressida, i: iii, 5.

Any one who has ever examined the case, or even one who has handled knotty lumber, has seen the wood fiber run around the persistent base of some dead limb, and can appreciate these lines. Such observer has learned the origin of a knot.

All these quotations show that Shakespeare used his own eyes and used them well. He saw the real distinctions of things, the hoariness on the willow leaf. $\mathrm{He}$ found character in the oak as in the king, and beauty in both. In many of his notices of natural objects, however, the poet is not the original observer. He portrays a character by allowing him to quote current opinions, fancies, dreams, for these also were the realities of that day, quite as much sometimes as oaks and forests. There is concerning plants a sort of orthodox mythology, and thousands of years have sometimes contributed to the 
reputation borne by a single species. A curious illustration is found in what Shakespeare has to say about the mandrake:

"Give me to drink mandragora.

Why, madam?

That I might sleep out this great gap of time.'

- Antony and Cleopatra, i: $\mathbf{}, 4$.

And again :

"Not poppy, nor mandragora,

Nor all the drowsy syrups of the world,

Shall ever medicine thee to that sweet sleep

Which thou owedst yesterday."'

-Othello, iii: iii, 330.

Juliet, reflecting on her proposed entombment in the dark grave of the Capulets, exclaims :

"Alack, alack! is it not like that I,

So early waking, what with loathsome smells,

And shrieks like mandrake's torn out of the earth,

That living mortals, hearing them, run mad;

Or, if I wake, shall I not be distraught,

Environed with all these hideous fears?"

-Romeo and Juliet, iv: iii, 45.

The mandrake Atropa officinalis belongs to the Solanacece, and, like others of the family, has narcotic properties. This was doubtless known to Shakespeare, as in the passage cited he compares the mandrake with the poppy. The groaning and shrieking are, of course, the purest superstition. The root of the mandrake was supposed to resemble the human form. The favorite habitat assigned to the plant was the foot of the gallows, and men believed that in some way the bodies of criminals 
were reproduced in the growing plant; their very pains and cries renewed, especially for him who profanely dared to pull the mandrake from the earth. The curious may consult Gerarde.

These ideas, it is needless to say, are very old; Pliny refers to them, and, if I recollect well, Vergil has his hero pull up some wild plant amid the strangest of sights and sounds. With these old myths are tied up, perchance, the mandrakes of King James's version. Nay, the superstition still survives; look at the wood-cut in Webster's Unabridged, and you will discover that the artist who set out to illustrate the word mandrake for that somewhat venerable authority was by no means able to free himself from the ancient spell. Credulity is evermore a factor in the compound called human nature. Men love to be fooled, or to find some support for belief in manifest absurdity. There is nothing so silly but has its advocates among men who ought to know better.

A year or two since, a man brought from Ohio to the University of Iowa an innocent five-parted, digitate, black fungus. It was treasured in alcohol. Why? Because of its origin! An honest mechanic, meeting with accident, lost his fingers under the surgeon's knife. The amputated members were neglected, but presently discovered and duly buried in the garden. The following spring from the "identical spot" uprose a swarthy hand, black without, white within. The hand was a perfect main-de-gloire for that sensation-loving community. The matter was discussed in newspapers. A long and careful account of the wonder was prepared, put in print, and circulated among the friends of the deceased - fingers! 
"What fools we mortals be!" For sheer superstition and crass stupidity who may say that the nineteenth century may not yet discount the days of the Virgin Queen?

But I said at the outset that Shakespeare had in some instances anticipated modern scientific teaching. To illustrate this in its most striking instance, I am compelled to offer a somewhat long quotation:

"Polizenes. Shepherdess,

A fair one are you, well you fit our ages

With flowers of winter.

PERDITA. Sir, the year growing ancient,

Not yet on summer's death, nor on the birth

Of trembling winter, the fairest flowers 0 ' the season

Are our carnation and streaked gillyvors,

Which some call nature's bastards: of that kind

Our rustic garden's barren; and I care not

To get slips of them.

Polixenes.

Do you neglect them?

PERDITA.

Wherefore, gentle maiden,

There is an art which in their piedness shares

With great creating nature.

Polixenes.

Say there be;

Yet nature is made better by no mean,

But nature makes that mean; so, over that art

Which you say adds to nature, is an art

That nature makes. You see, sweet maid, we marry

A gentler scion to the wildest stock,

And make conceive a bark of baser kind

By bud of nobler race: this is an art

Which does mend nature, change it rather, but

The art itself is nature.

PERDita.

Polixenes.
So it is.

Then make your garden rich in gillyvors, And do not call them bastards." 
Here we have brought out very distinctly the effect of cross-fertilization in flowers, the result of grafting and the development of varieties. Better than that, we have here the recognition of that tendency in organisms to vary that lies at the very root of the development of species. Natural selection, survival of the fittest, were impossible were it not true that "nature is made better by no mean but nature makes that mean"; or, as it is more broadly stated a few lines further on, "This is an art which does mend nature, change it rather, but the art itself is nature." I consider these very remarkable statements when we reflect on the time in which they were written. Darwin, in 1859, does but unfold the thought. The selection which Shakespeare notes as practiced by gardeners, and a similar selection seen in the world of domestic animals, gave Darwin his cue of natural selection. The beauty of Darwin's thesis lies in the fact that the process is natural, and such is Shakespeare's dictum.

Later on, lines 112-128, Perdita brings out another remarkable observation that has only lately been confirmed by the conclusions of science:

66. . Now my fairest friend,

I would I had some flowers 0 ' the spring that might

Become your time of day; and yours; and yours;

That wear upon your virgin branches yet

Your maidenheads growing: O Proserpina,

For the flowers now, that frighted thou let'st fall

From Dis's wagon! daffodils,

That come before the swallow dares, and take

The winds of March with beauty; violets dim, But sweeter than the lids of Juno's eyes 
Or Cytherea's breath; pale primroses, That die unmarried, ere they can behold Bright Phœbus in his strength - a malady Most incident to maids; bold oxlips and The crown imperial; lilies of all kinds; The flower-de-luce being one!",

Primroses are dimorphic; that is, on the same species we find flowers of different sorts. These are complete, but in any particular flower the essential organs fail of adaptation to each other - the style in one too long, in another too short, to receive pollen from the stamens of its own flower. For fertilization such flowers are absolutely dependent upon the assistance brought by insect visitors. Perdita's primrose is Primula veris, the early primrose, "that takes the winds of March with beauty," and dies ere it beholds "bright Phœbus in his strength," and it is precisely this species that forms the basis of one of Darwin's earliest and most fruitful studies in the cross-fertilization of flowers. The styles in one form of the early primrose are three times as long as in the other, the stigmas differ, and the co-adaption of the parts of the different flowers extends even to the grains of pollen. Such flowers in the absence of insects are entirely unproductive. Insects are rare so early in the year, and accordingly many of the primroses die, as Perdita says, "unmarried."

Of course, it is not pretended that Shakespeare knew anything of this; but that he should have discovered the fact that the early primrose bears little or no seed, and that he should have been impressed by the truth that this is due to lack of fertilization, is wonderful. This cir- 
cumstance might well lead to the suspicion that the poet was a gardener.

We must not forget to notice, too, in this connection, that carnations - i.e., pinks - are remarkable for the great number of their varieties. We have, if I may so say, pinks of every color, from white to crimson, even brown it is said. This was true in Shakespeare's time, if one may trust Gerarde again. He says, "A great and large volume would not suffice to write of every one at large considering how infinite they are, and how every year the climate and country bringeth forth new sorts and such as have not heretofore been written of."

Another beautiful passage, in which the poet has unwittingly hit upon scientific truth, is found in Sonnet V, the last ten lines. The beauty of the passage as a whole is so remarkable that the delicate touches in particular lines are apt to be overlooked:

"For never-resting time leads summer on

To hideous winter and confounds him there;

Sap checked with frost and lusty leaves quite gone,

Beauty o'ersnowed and bareness everywhere:

Then, were not summer's distillation left,

A liquid prisoner pent in wall of glass,

Beauty's effect with beauty were bereft,

Nor it nor no remembrance what it was:

But flowers distill'd though they with winter meet,

Leese but their show; their substance still lives sweet."

The reference here, no doubt, is to a perfume-bottle, a vial filled with the essence of the flower. ${ }^{1}$ This is the

1 Sir Sidney Lee, Works of William Shakespeare, cites here Sidney's Arcadia, bk. iii, p. 246, ed. 1674. 
figure. But the picture presents the confusion of life, checked by the onset of winter, and is curiously exact. No botanist can read the line,

"A liquid prisonér pent in walls of glass,"

and not recognize the exact portrayal of the living vegetable cell. The living protoplasm is a liquid prisoner, sure enough, hemmed in by walls transparent. There could be no more striking image. And when in herb and tree, in every living plant, the summer's work is ended and "hideous winter" falls, the new cells, summer's distillation left, do in all perennials actually survive, lest of the effect of beauty, beauty be bereft. There is no more marvelous picture in all the vegetal world than that of a great tree with all its myriad cells, in summer so filled with the rush of life's activity and change that we might hear its music, in autumn sinking to quiescence, and the winter's silent chill where liquid prisoners sleep pent in walls of glass. The poet, to be sure, knew nothing about this; he probably wondered, as we all must do, at the winter-sleep of plants; but after all, his simile turns out to be correct; he simply prophesied better than he knew. The only natural science which Shakespeare knew was gardening - if that may be called a science. His Sonnets are supposed to have been written about 1590 , and the first scientific glimpse of the real "prisoner pent in walls of glass" came about 1670, through the lenses of Nehemiah Grew, a Puritan physicist and botanist.

I am aware that it is said by some that in a study such as this, we are apt to read much into the writings of our 
author. As concerns this last quotation, such is confessedly the case; but the intelligent reader, I think, will find no possible basis for such judgment in our interpretation of the other passages we have studied. The poet's words are generally unequivocal. Of course, the language is poetical, metaphoric, but the metaphor has reference to something else; the description is not the metaphor. But, in fact, should we expect in Shakespeare very exact or complete description even? Yet, as it now appears, the description is often marvelously exact; always definite and clear, as far as it goes. Really, the artist has not room for much; his canvas is too small. $\mathrm{He}$ is thus limited to suggestion. His art, indeed, lies precisely there. The deep impressions a man of genius makes upon our minds lie often, if not always, in what he does not say. A word or two and the vision rises, whether in nature or in life, a passion or a landscape. Take the broken phrases of Ophelia depicting her broken heart, her "no more but so"; or the picture of the winter woods in Sonnet LXXIII :

\section{"That time of year thou may'st in me behold}

When yellow leaves, or none, or few, do hang

Upon those boughs which shake against the cold, Bare ruin'd choirs, where late the sweet birds sang.'

Does any one pretend that we are reading into the lines when we appreciate the marvelous sorrow of the one picture or the exquisite truthfulness and splendor of the other?

Shakespeare's natural eye was clear indeed, but none the less he seems to have seen everything with the eye 
of his mind. Faraday so saw the world of force, Newton of mathematical law, and Tyndall's "scientific use of the imagination" lies in the same direction.

And so the man of science and the poet have much in common. Both use the natural world, and the imagination is for each an instrument of effort. The poet's generalization is a splendid vision in a world ideal, suggested, no doubt, by what is actual, and liable here and there to coincide with truth; the generalization of the scientific man is likewise a vision, but it rests upon the actual, upon the ascertained fact at the greatest number of points possible, and disappoints us only that it is not everywhere coincident. The poet dreams of Atlantis, the lost continent, the islands of the blest, and builds us pictures that vanish with his song; the man of science too beholds the continents rise; scene after scene he likewise makes to pass across our startled vision; but his are history; his tapestries are wrought in the loom of time.

The poet writes the book of Genesis, with the herbs bringing forth fruit after their kind; the man of science figures fossil leaves and cones and fruit. Only at the last do poetry and science again agree:

"The cloud-capped towers, the gorgeous palaces, The solemn temples, the great globe itself Yea, all which it inherit shall dissolve, And like this insubstantial pageant faded, leave not a rack behind!"

And when the man of science gathers all his data, and collates fact with fact, and builds the superstructure of his vision, with him, too, all things fade and vanish in the infinity of the future. 


\section{THE FOLK-LORE OF PLANTS}

In the first place let it be conceded that the folk-lore of plants would seem to offer little of value in the matter of modern scientific research. Folk-lore is tradition, at best; and a tradition of times when of accurate knowledge, of science, there was none. It is a far-away echo of the earlier voices of humanity concerning itself and its environment, especially concerning the phenomena of the living world. Folk-lore is the survival among us in our adolescence - or is it senescence - of those fears and fancies, guesses and beliefs, which tortured, amused, or comforted our racial infancy and childhood. The knowledge of such things, even if accurate, ean be of service only in so far as it may help to frame a picture of the mental attitude, mental strength of men of the faroff past; only as it may help us to conclusions where our inheritance from antiquity perchance more profoundly affects the present. If we know a man's attitude toward nature we are in position better to understand, to appreciate his literature, his art, his faith.

The blind man, on recovering sight, saw "men as trees walking," i.e., he could not distinguish between men and trees. Primitive men, our intellectual ancestors, waking to consciousness, seem to have experienced a precisely similar difficulty; they failed to differentiate themselves from the world about them. To primitive man, everything had personality; all forces of Nature, of course, 
such as the wind, the lightning, the fire; but as well objects animate and inanimate, springs, rivers, rocks, weapons, implements, nor less plants of every sort, cereals, flowers, fruit-trees, trees of every kind; each external object was to him quite like himself. If he were a person, all these things were persons, too; they had, of course, personal power, as he did; certainly they had will; they might be entreated, worshiped even; in fact, were worshiped and are worshiped even to this day.

Plants are very curious things; they live indeed, but they are so very silent, mute; some have colored sap, red, purple; do such not bleed? Their leaves rustle, whisper, and sigh in the gentle airs of night, shall we not listen? There is "a sound of a going in the tops of the mulberry trees," shall we not bestir ourselves? Even in the winter, the giants of the forest stretch their great arms; their rubbing branches creak and cry, shall mortal man not fear? Plants are very curious things.

Plants, moreover, toward men were generally harmless, if not altogether friendly. Fruits and grain yielded nourishment and delight. The greater plants afforded shelter, shade. All the more familiar and harmless beasts likewise were beneficiaries, dependent upon the vegetable world. Even the plants less directly serviceable to mankind served the brute creation, and health and happiness seemed bound up in their very leaves; for the great herds of herbivorous creatures were seldom sick; so that long ago the plant world attained a reputation for therapeutics, and men sought and found relief from pain. Nor was this all; plants pierced the earth, entered the secret chambers of the mountain, and seemed to know the place 
of silver and all hid treasures. Their roots had power to rend the rocks and to pull down the banks of streams, disclosing thus all manner of bright and precious things; even dainty herbs seemed to make for themselves a triumphal way on the cliff-face all unscaled by human effort, even the utmost. Plants were accordingly miraculous, wonder-working; some seemed to possess the secret of immortal life; their roots touched the unseen springs of peace, their branches drew inspiration from the viewless air, their fruits failed not through all the countless years. How unlike the uneasy rudeness of human life as it must have been in that far away morning when feeblest creatures, urging forward day by day, on and on, along humanity's predestined way, pushed to a future utterly unknown and unsuspected; ever forward, along the blindest of roads vexed by pain and strife, o'erhung by clouds heavy with constant fear, perpetual boding, incomprehensible alarm!

Out of such conditions came the plant-lore of prehistoric times. What men thought about plants determined somewhat their own behavior, made their history, and in so far affected ours.

The information we have in reference to all these matters is to some extent, of course, merely a matter of conjecture, nevertheless there are several lines along which real intelligence may come. In the first place, as might be suspected, literature, from earliest to latest, touches it. Again, the names of plants often bring with them a glimpse of their primal significance; this is especially true of common plant-names among the people of western Europe. But, more interesting than all, many very 
ancient bits of plant-lore are still current, a matter of practical experience among men. Superstitions, survivals, hold-overs are these, much as old phraseology still lingers in our documents, legal, theological, and other.

It is impossible, of course, in a brief paper such as this to treat the subject with completeness; volumes would be, have been, necessary for that. I may instead in the few minutes assigned me here, be permitted to cite just a few instances which may illustrate the theme, and indicate somewhat the far-reaching vistas which it opens to curious and reflective minds. Let us be content, since perhaps the vista is all that any subject may afford.

One of the most curious of these old-time notions suggests that certain herbs have power to discover things out of sight, or naturally hidden. Often these plants are of the smallest and feeblest. Thus the Saxifraga, saxifrage, was evidently a rock-breaker among the Romans when first they framed the name; doubtless to these practical people a tradition merely, since similar plants are burdened with equal functions in the traditions of nearly all Indo-European peoples. In that age paradisiacal, when the number of thieves was limited to forty, the mere pronouncing of a word, the name of a little flowering plant, accomplished wonders, and became the "open sesame" to countless treasures. The sesamum seed is a little thing, not much bigger than a grain of mustard, or the faith for which that stands, and yet the tradition of its energy is the inheritance of every language. "Wit and good breeding," says a recent newspaper writer, "are the open sesame to the highest social circles in Boston." Doubtless no higher estimate has 
ever been suggested to indicate the power of these magic syllables.

There are many other plants to which age-long practice and tradition assign a similar virtue. The common hazel has a reputation for discovery transcending sesame. It has also other virtues. One day in Switzerland I saw a clumsily shapen cross in a shop-window, fastened against the window pane. I heeded it little until a second glance showed that it was the hazel. Knowing the lore of the little tree I made inquiry and learned, in fact, that throughout southern Germany hazel rods, especially in form of a cross, are good protectors against lightning, sinee on their flight into Egypt, the Holy Family found a hazel bush an efficient refuge in the time of storm. But the cross is a baptized hazel, so to say. The plant was famous long before christianity carried its emblem to any part of Europe, or even its founder had lent the cross its present honor. The hazel was a lightning plant, sacred to Thor, as was the ash, and hazel and ash bloom together in many an ancient legend. Sometimes one, sometimes the other has precedence. For thousands of years the rod has been the symbol of authority; was perhaps the original scepter, probably because of its convenience as an instrument of enforcement. By means of a rod the wonders were done in Egypt; but according to Hebrew tradition Aaron's rod that budded was an almond switch. I am in doubt about this, when I read that in the old languages the words for almond and hazel are the same. Jacob's trick-rods were hazel, as it appears, and hazel was and is the charmed wood of our own ancestral peoples. The divining rod, which John 
Fiske discusses at large, and believes the symbol of lightning, has come down to us, preferably a hazel; although I regret to say that I have seen box-elder used instead. I say it has come down to our own times. As a child I saw it used in Henry county; in Kansas I saw it in 1870. It was reported in use in this county (Johnson) to discover subterranean veins of water, water-couches we should now say, as late as 1880 , and no doubt since, although I have not taken trouble to enquire. Fifty years ago men found water almost anywhere on the undrained prairie by digging a hole ten or fifteen feet deep, so that in those days the water-witch, so-called, was almost uniformly successful in his time-worn vocation. To-day when for full supply the farmer must penetrate the rocks, sinking his pipes from a few hundred to a few thousand feet, the diviner has grown silent; who could expect the hazel sensitive to depths like that? The old forked stick has helped the kitchen fire, and what geology has to say about deep-lying St. Peter's sands will soon, let us hope, make all men wonder that twirling thumbs and solemn eyes had ever even claimed the attention of men of sense. So deep-seated was the belief in the power of the hazel that when white men came to North America and found here a splendid bush with the strange habit of postfoliar autumnal blooming, they forthwith assumed this the omen of some added but mysterious virtue, dubbed our beautiful American shrub the witchhazel, and under this singular title it blooms at this hour here in Iowa City.

But the folk-lore of the hazel would take all our time. Suffice it to say that for variety's sake other woody 
species appear sometimes to have shared these honors. The ash has been already mentioned; its fame, as we know, fills the myths and legends of the northern world. The oak belonged to Thor, and in all Aryan tradition as well, it is the lightning tree. "It was the law of the Ostrogoths that in the forest one might hew what tree he would, save only the oak and the hazel," and we are all familiar with the stories of sacred oaks in Britain. Many very ancient trees in England, France, and Spain owe their presence among us to this lingering superstition which protects the tree of Thor and Jove, and even of Jehovah, if we rightly read our much-forgotten bibles.

Within a few days we shall be hanging all our windows with evergreen, mistletoe in preference, in honor, we say, of Christmas. As a matter of fact, mistletoe is far enough from Christmas; has not even, like the hazel, been baptized. Its use is wholly pagan and dates from the same background of human history from which come not superstitions only but a thousand things we most esteem. Our fruits and grains are of such far-off antiquity; but the mistletoe was the friend of man the grain-user; when duly placed, it saved him from lightning, from witcheraft, which was worse, and from disease, and especially saved his stores of seeds and wheat from fire. When the wheat was gathered, a sprig of mistletoe was placed in the middle of the heap. Mistletoe means mist-rod; it is an evergreen parasite on the oak and hence doubly sacred; for the oak, and for the incomprehensible mystery of its life. The Germans call it donnerbesen, the broom of thunder.

Many another tree might lend itself here to fanciful 
discourse did time and your patience permit; the white thorn with its dream of death, and the cypress with its melancholy shadows; old, both of them, as the transmitted speech of men; and to-day white are the lilies above the coffined dead, and dark the shadows of the cypress-trees, so that Whittier could say:

"Oh well for him whose faith yet sees

The stars shine through the cypress trees."

Christianity, of course, as already intimated, touches lore of every sort, plant-lore more surprisingly because it was so much more extensive. The sunlight of the life of Christ is on all the fields. The lilies are more wonderful since he taught us how to esteem them, although we have waited till this good hour to obey his injunction when he bids us consider how they grow. His lilies may not have been lilies; but the Greek - the Persian knew lilies, if the Hebrew did not, and the Greek's artistic touch lingers when we say that "In the beauty of the lilies Christ was born -." I believe, however, that Buddha's lotus, the water lily, figures here.

As a further index of the spread of Christianity, we may note that crucifixion-thorns are in all lands. Away down on the Mexican desert I found an outcast plant, the thorn of the passion, as the natives think. It grows there leafless during the greater part of the year, and comes into service, strangely enough, when fanatic devotees lash themselves as penitentes. All over California, men cultivate the passion-flower, with the very nails present, as it would appear, surmounting the crown of spines! Not far are we yet from the mental attitude 
of our forebears. We love fable and fancy, and believe the miraculous. Lack of truth is the vice of the race. In my attempt to do the work of science I find it extremely hard to tell the truth, to distinguish between what I think is true from what is true. The man on the witness stand tells what he thinks is true.

But the folk-lore of plants gives everywhere abundant instances of the impress of Christianity, and especially of what might be called biographic Christianity. The simple peoples of the northern world were taught the lives of the saints; the story of Mary, and the rest; and all the flowers of the field reflect the fact. The maiden hair is our lady's hair. We have lady's bedstraw, lady's thistle, lady's tresses, lady's thimble and lady's mantle, lady's comb, lady's looking-glass and cushion. While the roses are all hers, and even the threaded beads, upon the weary fingers of that simple kneeling creature on the hard floor of the cathedral, yonder, who can pray but who can do no more - even the threaded beads are the rosary of her faith.

Saint John, i.e., John the Baptist, has plenty of commemoration. The karob, once part of the prophet's meagre diet, is St. John's bread. St. John's-wort is a beautiful family of flowers, the name transferred here to our woodland meadows; even currants are in Germany Johannesbeeren and Artemisia is the proto-baptist's beard! Veronica is the name of our little speedwell, and both these names bring memories. St. Peter's-wort is a primrose; a bunch of keys; in German, himmelschlüssel.

A great many of the popular names of plants in all countries are attended by legends; each name comes from 
generation to generation accompanied with an explanation, a story, often interesting enough, that should enable us to understand the reasonableness of the appellation. For such stories those interested are directed to the wide literature of the present subject.

I referred in the outset to the fact that names in themselves sometimes bring curious information. A remarkable illustration of this is found in the survival today of traces of the ancient doctrine of signatures. In their despair at rightly selecting the proper herbs for the recovery of the sick - for we must recall that in all ages the leaves of the tree were "for the healing of the nations," - in the effort to fit the remedy to the trouble, some poetic genius suggested that it was irreverent to suppose that God might have created herbs expressly to cure people and yet have left his children entirely without any means, save experiment, for identification. The suggestion was that the form of the plant or its leaf was an index to its specific value, the big " $S$ !" on the prescription, the signature or direction of the Creator guiding poor mortals to relief from pain. This idea was once thought to have come out of the dark ages, socalled, or in the middle ages when men were attempting to discover the identity of plants referred to in Greek medical works; but Indians and Chinamen have the same notion, so the fancy must be old. At any rate the idea was accepted and lingers yet among us. We have liverwort and spleenwort and lungwort and eyewort or eyebright, moneywort - all of us seek to use that heart's ease, etc. There is no end to it. All our pharmacopeia took origin in the traditions of empiricism, the 
credulity of the ignorant, and much of it persists now under the same conditions. There are people in Iowa who prefer to medicate themselves and their children with decoctions framed in the name of some wild "medicine man," rather than trust to the wisdom and science of their enlightened neighbors, the physicians. Look at the shelves of your shops, Indian remedies, Cherokee medicines, St. Jacob's oil, and tell me if we have journeyed far along the corridors of time. Science has great difficulty in discarding these old traditions. Year by year the plant list in the pharmacopeia is reduced. I have, perhaps, in my herbarium three hundred or four hundred medicinal plants; I believe that of these at least ninety-five per cent have no possible therapeutic value.

But there is still another phase of plant-lore that seems ineradicable among us. I refer to that which relates the prosperity of vegetables to the influence of the moon and the stars, particularly the moon, as that luminary is evidently so much larger. I suppose there are men in this city to-day who in all their gardening observe the changes of the moon. Tylor says that "in days gone by, neither sowing, planting, nor grafting was ever undertaken without scrupulous attention to the waxing or waning of the moon."

"Sow peas and beans in the wane of the moon;

Who soweth them sooner, he soweth too soon, That they with the planet may rest and rise And flourish in bearing most plentiful-wise."

In our boyhood days potatoes planted in the dark of 
the moon (or was it in the light?) were sure to rot in the ground. I remember that my father once, in defiance of advice, planted, and in the cold rains that followed for some weeks, lost his labor, to the great satisfaction of his more weather-wise neighbors.

Even intelligent men are still under this spell, particularly in reference to beans, which as we all know, refuse always to stay planted, but must needs rise forthwith in order to further vegetative attainment. A minister said to me not long since: "Do you not think the moon has something to do with it? Think how it pulls the waters of the ocean; don't you believe it might help the beans and potatoes some?" It has even been suggested that the Agricultural Department at Washington undertake experiment along these lines to ascertain whether or not there be any grain of truth in a popular belief so firmly rooted. Of course, in traditional medicine, all kinds of herbs vary in curative properties according to the phase of the moon under which the material is assembled. "Canst thou bind the sweet influence of the Pleiades or loose the bands of Orion?" What means that ancient shining distich?

It is perhaps, hardly necessary to refer now to the abundant plant-lore revealed in the Greek and Latin classics. Much of it, as already suggested, is the same as that of the northern nations; either the same because both derive from the same prehistoric source, or in a few instances, perchance, because our fathers have adopted classic traditions. We shall, of course, always bear in mind that the lore in any case was long established before 
literature could touch it: literature simply records what is.

Sacred trees and flowers lend their beauty to nearly all the legends of ancient Greece. Everybody knows how the laurel was sacred to Apollo.

"Phoebus sitting one day in the laurel tree's shade Was reminded of Daphne of whom it was made, For the god being one day too warm in his wooing

She took to the tree to escape his pursuing,', while

"Daphne before she was happily treeified Over all other blossoms the lily had deified."

Laurel leaves and berries crowned the victors in those old-time contests where art and wit and beauty vied; and still in the centuries since, men have won laurels in every honorable achievement, especially where learning and scholarship might claim the prize. Would that the tree were native to these newer lands and fields, and that fortune might find occasion once again for its classic use! How much more elegant the baccalaureate wreath than the colored millinery we derive, not inherit, from the semi-barbarian of the dark ages, frail imitations of the trappings of the Cæsars. The savage puts on paint and feathers; the sons and daughters of wisdom bear aniline-tinted tassels and ribbons.

The laurel was sacred to Apollo, but indeed all the flowers were sacred to the college of the gods. To Juno belonged the anemone, the lily, the asphodel, the poppy, and the violet; the pink to Zeus, the narcissus to Proser- 
pina; to Diana all the wild flowers that modern students love - those miracles of nature, the triumph of the ages, that fill the world unseen with color and perfume, and our hearts with startled but appreciative wonder. What must have been the vision of those old-time men who saw the personification of pure beauty, clear and cold as the silver circlet of the rising moon, a maiden lithe, touching with trackless footsteps the otherwise untrodden wild, where by murmuring stream the flowers of the woodland opened unabashed their gentle eyes of glorious delicacy and beauty. Diana and the wild flowers undisturbed; fairest picture in the gallery of the human spirit!

I have already mentioned the flowers of the Orient, I may refer again to Buddha and his lotus, the lotus older than Buddha, old as the monumental valley of the immemorial Nile, where thousands of years ere Buddha sat and dreamed for India, Egyptian priests carried the rose-tinted water-lily in their processions that signified the march of man beyond the tomb. Who shall tell the dreamy legends of the lotus, languid, floating on the silent waters; its fruit could make the souls of those who ate it more blessed than the care-free gods. Buddha in terrestrial birth rose from the lotus bloom, the beauty of the lily.

The asclepias, which still lingers in our pharmacopeia and blooms each recurring autumn by Iowa streams, has a history stranger still. Here is the tree of life that grew in paradise, untouched of men. Its milky juice brings immortality; itself can never fade. The vedas call it soma and sing its praise: 


\section{'We've quaffed the soma bright \\ And are immortal grown, We've entered into light And all the gods have known; What mortal now can harm Or foeman vex us more? Through thee, beyond alarm Immortal god, we soar." 1}

We started out in this discussion with the concept that much folk-lore originated in the thought entertained by prehistoric men that plants were not unlike themselves; all the more wonderful powers since attributed to flowers and trees would seem to confirm that view. The wonder-working twig or bloom or fruit is endowed with personality, may confer pain or joy, bring bane or blessing, even the penalties or blessing of the Lord.

Just how far we have left these idle though ofttimes poetic fancies my hearers may judge if I cite a little of the plant lore of the present.

Gustave Theodore Fechner, ${ }^{2}$ the philosopher of Leipsic, died in 1887. He is regarded as the founder of scientific psychology, Wundt and Paulsen and Lasswitz call him master. In his earliest book, Nanna, Fechner tells of plants. He holds that plants are conscious, "they spread their organs abroad; they drink in light and air with their leaves," and "feel their rootlets draw the sap" - they "enjoy something like what we call pleasure in ourselves." "How scanty and scattered

1 Translated by Sir William Jones; The Folk-lore of Plants, by T. F. Thiselton Dyer, N. Y., 1889, p. 246.

2 These notes of Fechner are from James, $A$ Pluralistic Universe, Lecture IV. 
would sensation be, if the feeling-life of plants were blotted from existence" - Fechner goes farther still: he finds consciousness in all things inanimate as well as living; even the planet lives again and is conscious, and in the nineteenth century the goddess Gaia or Terra returns again unto her own. Listen then to Fechner as translated by the marvelously open-minded Professor James:

"On a certain spring morning I went out to walk. The fields were green, the birds sang, the smoke was rising and here and there a man appeared; a light as of transfiguration lay on all things. It was only a little bit of earth; it was only one moment of her existence; and yet as my look embraced her more and more it seemed to me not only so beautiful an idea but so true and clear a fact that she is an angel, an angel so rich and fresh and flower-like and yet going her round in the skies so firmly and so at one with herself, turning her whole living face to heaven and carrying me along with her into that heaven that" I asked myself how thinking men could ever have deemed the earth a clod!

Is consciousness then a property of universal matter? Truly when the shaping fancies of our racial morning begin to blend with modern learning and to echo in our most recent university halls, it is time to give some heed at least, to the folk-lore of the plants. But, friends, there is nothing in it: is it at all worth your time and mine? 


\section{SIGMA XI}

It becomes my very pleasant duty this evening to bid you formal welcome to the associations and privileges of the brotherhood known as the Sigma $\mathrm{Xi}$. In the discharge of this duty I am also to set before you very briefly the aims and purposes of this organization and to encourage you to yet more serious and earnest effort in fields of original research such as the Sigma $\mathbf{X i}$ is set to foster. I bid you welcome to a goodly company. Sigma $\mathrm{Xi}$ was organized in 1886; it has ever been very exclusive, but now includes in its membership all the principal scientific men of the country, and has a chapter in every prominent university in the United States. Its motto is $\Sigma_{\pi \circ o v \delta \hat{\omega}} \Xi_{v v \omega \hat{v} \in s,}$ companions in research, those who strive together in study. The objects of the society may not be better set forth than in Article I, Section 2 of the constitution:

"The object of this Society shall be to encourage original investigation in science, pure and applied; by meeting for the discussion of scientific subjects; by the publication of such scientific matter as may be desirable; by establishing fraternal relations among investigators in the scientific centers; and by the granting of the privilege of membership to such students as have during their college course given special promise of future achievement."

The conditions of membership are, as you observe, pe- 
culiar. They rest not upon university credits, not upon courses of study as such, least of all upon grades or standings so-called, carried out to any perfection of decimal refinement, but upon the one solitary condition that in your work in the University, your scientific work, you have in the judgment of your instructors given promise of being able presently to guide your own work yourselves; to take up and carry forward on your own account some investigation, some problem which in its completion or solution shall be a contribution to the sum of human knowledge. It is our confidence in your ability and willingness to do this thing that has brought us here face to face this evening.

The membership in Sigma $\mathbf{X} i$ is then conditioned upon presumed ability to enter upon and carry forward original scientific research. Such ability, though not always a matter of record on the books of schools and universities, does nevertheless, for its successful exercise, require, in addition to natural endowment, certain high attainments of scholarship and the observance of peculiar definite conditions in themselves sufficiently rigorous and imperative. Research-work is not for the sluggish nor for the ill-informed. No really valuable effort to enlarge our knowledge is accomplished without long preparation and patient unwearying toil. The very first prerequisite is knowledge, knowledge of what has been done by others, especially in the field selected. This, of course, for many reasons, not the least important of which is simply selfprotection. Surely no one cares to take up a line of investigation simply to repeat or duplicate the observations and experiences of another, unless, perhaps, by im- 
proved appliances, or facilities, or opportunity he is reasonably certain that he can add materially to the sum of facts already known. For instance, much is known concerning the behavior of the dividing nucleus in the cells of the higher plants : no one desires to repeat the work of investigators in this field unless some new reagent, some new method of treatment, some new lens may give promise of affording new light in fields already well explored. The would-be investigator must know the existing state of knowledge if he would not in large measure waste his time and lose his pains.

But there is still another demand for the widest kind of knowledge; the research student must know his subject thoroughly in order wisely to select, in order to render his contribution in the highest degree useful to the particular science he affects and so to the science of the world. A man has been known to spend a life-time upon a problem which when solved forwards in no least particular the general purpose and sweep of the science, nor aids in any way whatever his fellow-workers in that particular field. There stands in my library a volume of more than a thousand closely printed quarto pages. It represents the entire life-work of a most diligent and painstaking student; yet it is all practically labor taken in vain. It attempts to record the first naming of every known plant in all recorded literature - the chronological history of plants. Now the volume is a mass of curious erudition, a lore culled from all the languages ever written among men, yet to-day no one every quotes that volume, no one seems ever to find occasion to refer either to the author or his work, his labor brings no 
smallest comfort or assistance to any naturalist in any field. The author in his desire for originality eschewed the science of his time and is said to have even kept secret his self-imposed task until near the close of a long life when fear lest his work be left incomplete induced the publication of his purpose. Needless to say that is not the true spirit of research. The student must exercise good judgment, and this exercise ought to have high regard for the work of others as they toil about him. In fact he should feel constantly the kindliest sympathy with all who have ever garnered in his field before; he must be able to appreciate their successes as well as to discover their difficulties and failures. His work should be in the main constructive, and while it may not infrequently be necessary to recast or revise the conclusions of those who have gone before us, yet we can never wholly ignore them. In a most real and reverent sense we may always say: "Other foundation can no man lay than that which is laid."

Of course, I would not have the investigator here too conservative; he must be untrammelled; he must be perfectly free. Above all, he must not, he dare not imitate. That which every man can do best in this world no other man can do quite so well, such is the law of natural gifts. We must appreciate our fellow-worker but we dare not copy him. If we do we are apt to gain but half his strength and to lose our own entirely. Nevertheless the true laborer along the lines suggested by Sigma $\mathrm{Xi}$ must know and know with sympathy.

But Sigma Xi demands yet other qualifications of those who would worthily bear the name. It was re- 
quired of the candidate for initiation into the Eleusinian mysteries of old that he place himself for days under certain definite restraints, he must for days exercise perfect self-control. Such self-restraint and of yet higher order is required to-day of every scientific worker. It is hard, very hard, to toil in silence, without reward, without applause, without approval even; yet just such toil lies at the bottom of every real piece of successful work. The inexperienced student is apt to be eager to bring his work to light. He fears, perchance, that another may prevent him, preclude him, and it is sometimes very trying to normal patience to quietly labor on to the satisfactory solution of our problem when of necessity time is likely an all-important factor. Neither Wallace nor Darwin ever published a preliminary report. It is said that the note-books of Mr. Darwin for the single work, the Descent of Man, would be reckoned a small library and opposite a great many of these manuscript notes and memoranda copied out with the utmost pains, often in his own hand, appears the author's final comment: "This statement seems to be unfounded"; "this is a mistake"; and so on in scores of cases.

Every man assuming to do original work must be his own severest critic. Science deals in facts, and yet only the man of science knows how hard it is to state a fact, how hard it is to tell the truth. Perhaps we never see the truth exactly ; the so-called personal equation forbids that; but to tell the truth as we do perceive it requires a degree of self-discipline that comes only, if at all, after years of practice and self-restraint. I am no slanderer of my race when $I$ assert that some men never attain this 
power at all. "Shoot an arrow and speak the truth" is said to be an oriental proverb. Telling the truth is like shooting an arrow or a rifle; no man does it by nature; he must learn. I have seen many men shoot, but never saw one hit the center exactly. If one did so hit the mark it were surely an accident; not more to be reckoned to the marksman's credit than many another shot that came very near but did not quite reach the same perfection of accuracy. So hard is it to report a scientific truth, even for the most accurate among us.

There is just one other thing here to say. The work that we undertake in this world is determined largely by circumstances, often by circumstances over which we have little or no control. Your work will be found precisely where you are. You need not go to Germany or London to begin. You may begin at Iowa City or at Ward's Corners; but wherever it is and whatever it is, whatever its kind or class, be assured the same laws hold fast, the same principles control. Patience, self-restraint, loyalty to the truth and to the work of others, these are the qualifications for service in the goodly fellowship of the Sigma Xi.

Never was the time more opportune. Everywhere is an open door. All the work that has been done hitherto has been but to clear the way for you. The work in higher mathematics has been voluminous, immense, but there is probably not a problem in mathematics but suggests others more varied and far-reaching still. In physies and in chemistry, as all the world knows, we are on the constant verge of expectancy. In geology there is probably not a county in the Mississippi Valley whose 
history has been so written as not immediately to suggest the necessity for revision. In the higher groups of plant-life the life-history of perhaps five-hundred is more or less definitely known. In the animal world we are only beginning to ask questions; even the whole problem of our relationship to the fauna at our feet is yet but dimly a matter of surmise.

Nor is this all for your encouragement. By private beneficence many of the universities of the country have established graduate schools for the express purpose of fostering research and original investigation. Carnegie's great gift at Washington is the most notable of these. The Carnegie letter sets forth his purpose, "which is to promote original research, paying particular attention thereto; to discover the exceptional man in every department of study, wherever and whenever found, and to enable him by financial aid to make the work for which he seems especially designed his life-work, to secure for the United States of America the leadership in the domain of discovery and utilization of new forces for the benefit of mankind."

This sounds almost like an endowment of the Sigma $\mathrm{Xi}$. Carnegie means simply that hereafter no research work shall suffer for lack of means to keep alive the worker. This will certainly be a source of wonderful help and stimulus. Many are no doubt turned aside even to-day from research as a career simply because of the uncertainty of securing therein a livelihood. "The laborer is worthy of his hire." Yea, verily; but no true son of science or of art labors for his hire. Mr. Darwin was fortunate in that private fortune left him without 
concern; Tyndall and Priestley were poor. Let us hope that Mr. Carnegie's money may bring forth abundant, early, and continual fruit. And yet I venture the prediction that the course of research will be for a long time yet to come a steep and thorny way and not the primrose path of dalliance. Wealth so easily falls in the way of industry and clips the wings of zeal! There is so much in this world that money cannot buy. I believe that rarely in this day, at least in this country, is research retarded by lack of sufficient means. The man who has the spirit in him will find the way. What we need most - and perhaps it is rather this that Mr. Carnegie intends to bring to being - is the right atmosphere, a generous atmosphere, where an assembly of men shall always be found whose ideals are the promotion of knowledge and nothing else. The Carnegie Institution shall be such a sodality of earnest men. High example is worth more than money and I believe that the bond of sympathy that runs through such an organization as the Sigma $\mathrm{Xi}$ is yet and forever worth more for science than all the millions of the generous-minded Scotchman.

What any individual may do is to some extent no doubt determined by his opportunity; nevertheless it is by what is done and not by the opportunity that each at last is judged. "What hath he done?" says Emerson, "is the divine question that searches men and pierces every false reputation. A fop may sit in any chair in the world nor be distinguished for the hour from Homer or Washington; but there can never be any doubt concerning the respective merits of human beings when we

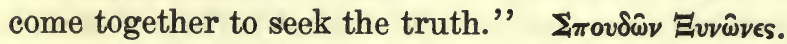




\section{SIGMA XI II}

The formalities which thus far it has been your privilege to witness have all had more particular reference to the organization of which you now become a controlling part. You have been told of things past; of what has been; of things to be kept in memory by tradition, or record more or less exact. You have assented to these things rather as indicative of the general trend of your own ambitions, your present purpose; and now there remains to complete these simple ceremonies but one procedure more; this for the moment has been assigned to me, and this now touches the hope, the expectation, the duty of each individual of this class and looks wholly to the future.

Research in this modern world were not scientific, were it not methodic; and, varied as it may betimes appear, touching as it does every conceivable phase of the tangible scheme of things, nevertheless in itself is comparatively simple and presents perhaps but three aspects, finds employment in three rather sharply limited fields of intellectual endeavor. In the first place, by dint of the toil and labor of the men before us in time, science has become possessed of a vast body of ascertained fact, facts in physics, in astronomy, facts in geology or botany; and it is evidently one important business of research to see how, if possible, these facts may be made serviceable in the economies of everyday life. Research 
shall wait upon the physical needs and comforts of man; science shall be applied.

It is needless to cite illustration here; accomplishment is everywhere familiar, far-shining as electric light, musical as the voices of distant friends, and far-reaching as the Hertzian waves. Men who care for wealth alone, for science not at all, have discovered that science pays; and, with the eagerness of those who seek for gain, such men to-day demand research in the solution of their problems. It is notably the business of applied science at this moment not only to tell how science has been applied, but to join hands with invention, to devise new application of discovered principles; to bring farther and farther the energies of the physical world into the control of enlightened man.

But, wonderful and valuable as this is, and the insistence of popular clamor will not allow us to forget it, there is behind all this another field of intellectual discovery, another empire of research of which the public seldom hears, but without which not only applied science but all science must cease to be. This is research for its own sake; research which has for its object the discovery of fact, all apart from any application which may afterward ensue. Marie Skolodowska and Pierre Curie toiled for thirty years or ever mankind should know of polonium and radium and the shining world of radio-active things that simply fascinate to-day the scientific man. That these should cure tuberculosis or lupus, was farthest from their thought; perhaps even to-day Mme. la veuve Curie knows nothing of it.

When Leeuwenhoek with his dim lenses noted the 
micro-organisms in a drop of water and strove to refute the idea of spontaneous generation, he did not know that he was laying the foundation for a science that would one day, as bacteriology, overturn the accepted hygiene of the world. He engaged simply in a bit of pure research, and the outcome is as we see. Even our fine apochromatic lenses we owe to men called amateurs, lovers, who sought to resolve the markings on the walls of minutest plants, the diatoms.

In 1845 Faraday dreamed of electro-magnetic waves that filled the universe with lines of force, as lines of light; twenty years later Clerk-Maxwell reached the same vision by mathematical equation. But in twentyfive years more, Hertz produced such waves and showed that these followed Faraday's dream and Maxwell's demonstration; outcome so beautiful, so fine, that when at length in 1907 Marconi's wires began to signal across the sea, scientific men, at least, noted it scarce at all; but the careless public became excited once Faraday's dream came true and his lines followed the Titanic on open sea more closely even than the wire-strung telegraph follows the flying train.

Science recognizes Marconi - oh, yes! - but holds in yet fonder recollection Faraday, Maxwell, and Hertz, who had no slightest "respect unto the recompense of the reward"; could not even forecast it. Science not yet applied, yea science that is yet to be, lies in the domain of pure research.

But brilliant as this is, there is yet another field in which the human mind may find employ, finer and more fascinating far; I mean the empire of pure thought; the 
realm of investigation which deals with the relations of things and whose only possible practical outcome is in the elaboration of instruments, tools, by which other forms of research may be more fortunately pursued, as when Maxwell's mathematics confirmed the inspiration of Faraday, moving through pathless space on lines of inexpressible complexity, invisible and yet secure. Here the mind is not disturbed by practical relation of any sort whatever; its exercise is pure intellectual delight. At Atlanta, in the winter of 1913, the president of Section " $B$ " of the American Association for the Advancement of Science declared that "Frazier's series reveals the transcendence of analysis over geometric perception. It signalizes the flight of the human intellect beyond the bounds of the senses." Applied science, pure science, scientific theory - ladies and gentlemen, in one or other of these great fields your privilege shall lie. Sigma Xi in this hour of your initiation makes of you but two demands :

1. Appreciation. She asks you to appreciate, to love with unusual devotion the kind of work to which your attention is thus so briefly called, and in which you no doubt have already found some experience, however slight.

2. Participation. She asks you, in so far as the circumstances of coming years allow, to devote at least part of your daily toil to some problem all unsolved; whether in the noble application of scientific fact to relief of human need; whether in the discovery of new fact, the proclamation of truth unheard; whether in the more lonely task, where only the laws of mathematical reason- 
ing may control, but where each new equation, each latest integration, throws its own new light upon the world unseen, to make pathway by and by for the future triumph, since one by one all physical problems of our world find refuge at the last in that energy and medium unknown, beyond the boundaries of the sight and touch. 



THIS BOOK IS DUE ON THE LAST DATE STAMPED BELOW

\section{AN INITIAL FINE OF 25 CENTS} WILL BE ASSESSED FOR FAILURE TO RETURN THIS BOOK ON THE DATE DUE. THE PENALTY WILL INCREASE TO 50 CENTS ON THE FOURTH DAY AND TO \$1.00 ON THE SEVENTH DAY OVERDUE.

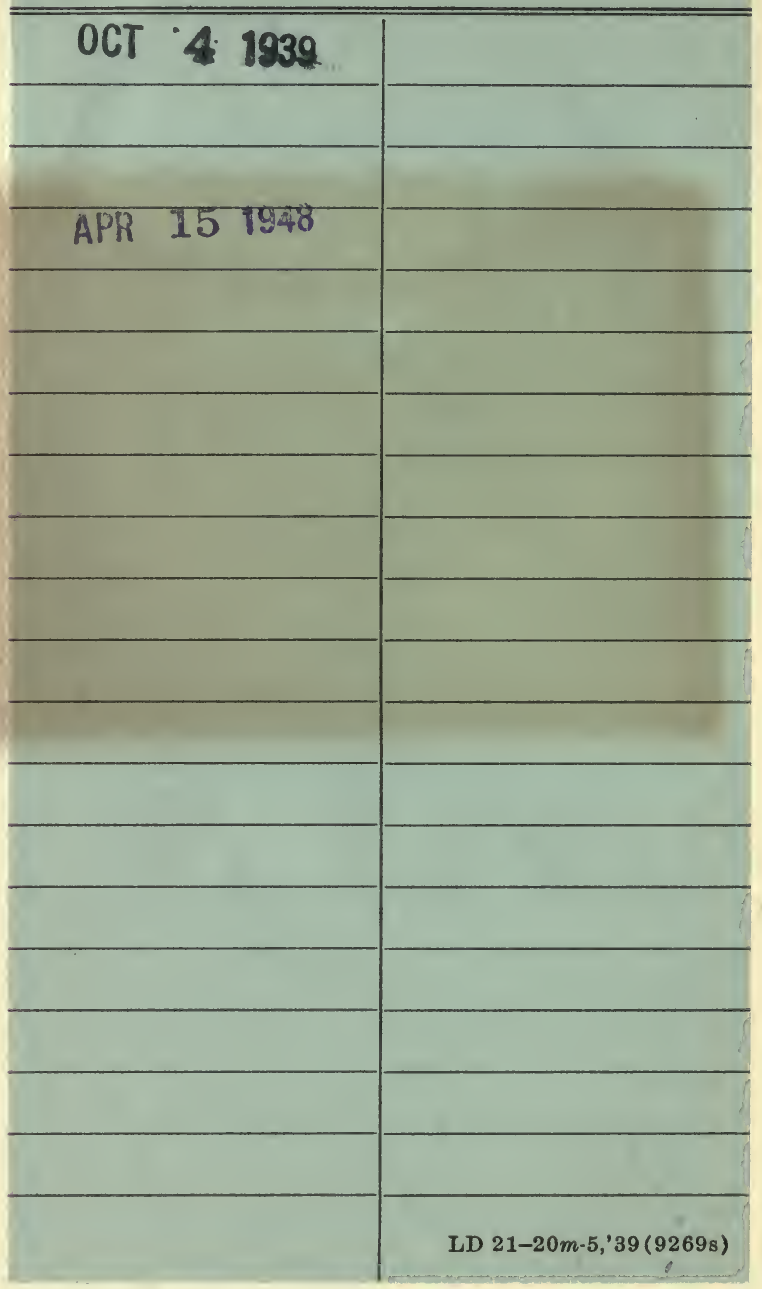




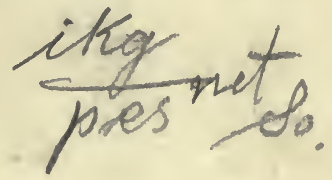

\section{YC 40761}

\section{9}

frica ditule

\section{UNIVERSITY OF CALIFORNIA LIBRARY}


